\title{
A REABILITAÇÃO AUDITIVA EM MOTORISTAS DE ÔNIBUS URBANO, PORTADORES DE PERDA AUDITIVA INDUZIDA POR RUÍDO (PAIR): PROPOSTA METODOLÓGICA
}

MÁRCIA TIVERON DE SOUZA

Tese de Doutorado apresentada ao Departamento de Saúde Ambiental da Faculdade de Saúde Pública da Universidade de São Paulo para a obtenção do grau de Doutor.

Área de concentração:

Saúde Ambiental

ORIENTADORA: PROF. DRA FRIDA MARINA FISCHER

Săo Paulo 2002

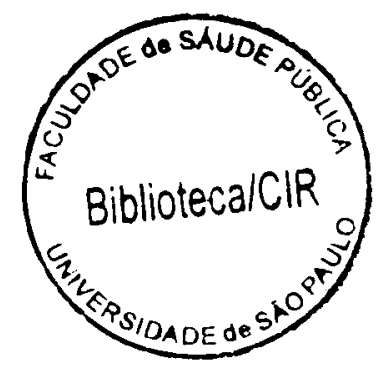


Autorizo, exclusivamente para fins acadêmicos e científicos, a reprodução total ou parcial desta tese por processos fotocopiadores ou eletrônicos.

Assinatura:

Data:

$42888 / 2002$ doc. 
Aos trabalhadores, nossa razão de continuar. 


\section{AGRADECIMENTOS}

A Profa. Frida Marina Fischer, pela orientação e pelo exemplo.

À Profa. Denize Cristina de Oliveira, por proporcionar um primeiro contato com a Teoria das Representações Sociais.

Aos colegas do CEREST-SP, por compartilhar de meu crescimento pessoal e profissional.

À Rosângela Jimenez Mastrochirico, pelo apoio na coleta de dados e por estar sempre presente.

Às professoras do curso de Fonoaudiologia da Universidade de Mogi das Cruzes, pelo constante apoio.

A Universidade de Mogi das Cruzes, pela concessão da bolsa.

A FAPESP que, por conceder a bolsa de mestrado, tornou possível o doutorado.

Aos meus pais, Olides Tiveron de Souza e Walter de Souza, pela retaguarda, sempre bem vinda.

Aos meus amores, Nicolau, Vitor e Laura. 


\section{RESUMO}

SOUZA MT. A reabilitação auditiva em motoristas de ônibus urbano, portadores de Perda Auditiva Induzida por Ruído (PAIR): proposta metodológica. São Paulo, 2002 [Tese de Doutorado - Faculdade de Saúde Pública da USP].

O ruído é um importante fator de risco presente nos ambientes de trabalho e também fora deles. A exposição ao ruído inicia-se cada vez mais cedo em nossa vida, e a convivência com ele faz com que menosprezemos suas conseqüências à saúde. Da mesma forma, o trabalhador parece não conhecer ou desvalorizar o ruído enquanto fator de risco. É necessário desenvolver ações que permitam a efetiva melhoria das condições de trabalho, e isso significa fornecer ao trabalhador instrumentos que o apóiem nessa tarefa.

A compreensão da dimensão dos efeitos do ruído pode ser melhor alcançada pela adoção de instrumentos de avaliação dos efeitos do ruído na vida dos indivíduos. Além disso, os trabalhadores portadores de PAIR merecem atenção especial, tanto em relação às possibilidades de reabilitação, como de adequação do ambiente de trabalho.

O objetivo deste estudo é elaborar e aplicar uma proposta de trabalho educativo-terapêutico de reabilitação auditiva em trabalhadores com dificuldades de comunicação pela Perda Auditiva Induzida por Ruído (PAIR).

Foi realizada avaliação audiológica (anamnese, audiometria tonal, logoaudiometria e imitanciometria) em 106 trabalhadores. Desses, 80 responderam a um questionário de percepção de handicap (HHIA). A partir desses 80 trabalhadores, foram selecionados 37 com perda auditiva e percepção de handicap, sendo convidados para integrarem os grupos de reabilitação. Os grupos realizaram três encontros, com a duração de uma hora. Dessa etapa, participaram 33 trabalhadores.

A análise dos grupos foi feita a partir da reaplicação do HHIA. Como instrumento de avaliação complementar, foi utilizada a técnica de evocação, 
da abordagem estrutural da Teoria das Representações Sociais, aplicada pré e pós-grupo.

Foi possível concluir que o grupo teve um papel importante, propiciando um espaço para reflexão sobre o processo saúde-trabalhodoença, levando também informações sobre o ruído e suas conseqüências à saúde. Os resultados também indicam que houve aumento na percepção do handicap, o que sugere que o grupo foi eficaz nesse ponto. $A$ análise das evocações demonstrou não ter ocorrido mudança nas representações dos termos indutores (surdez, comunicação, surdez e trabalho).

Foi também possível observar a existência de percepção de handicap tanto nos indivíduos com audição normal $(46,7 \%)$, como nos portadores de PAIR (74\%). Isso pode indicar a limitação da avaliação audiológica na análise dos efeitos do ruído e a necessidade de adequação desta por meio, por exemplo, de um instrumento de avaliação de percepção de handicap.

Foram feitas várias sugestões de melhoria do ambiente de trabalho e processo produtivo, por parte dos trabalhadores. 


\section{SUMMARY}

SOUZA MT. A reabilitação auditiva em motoristas de ônibus urbano, portadores de Perda Auditiva Induzida por Ruído (PAIR): proposta metodológica. São Paulo, 2002 [Tese de Doutorado - Faculdade de Saúde Pública da USP].

Hearing rehabilitation of urban bus drivers suffering of noise induced hearing loss(NIHL): proposed method

Noise is an important risk factor found not only in the work environment but practically everywhere.

People are exposed to noise starting from the early years of life, and those accustomed to live in noisy environment often underestimate the harmful effects on health.

Likewise, the worker appears not to knowing or accepting noise as a risk factor.

Actions are needed to effectively improve the working conditions, which means to provide workers with instruments to achieve this task.

The comprehension of the effects of noise can be better achieved through usage of proper instruments to evaluate its effects on individuals' life.

The workers suffering of NIHL deserve a special attention regarding the possibilities of rehabilitation, as well as the improvement of working environment.

The objective of this study is to design and implement an educational and therapeutic work plan regarding hearing rehabilitation of workers having communication impairment caused by NIHL.

Audiologic evaluation was carried out (anamnesis, tonal audiometrics, logoaudiometrics and imitationmetics) with 106 workers.

80 workers answered a handicap perception questionnaire (HHIA).

Out of these workers, 37 persons suffering of hearing loss and perception of handicap were selected and invited to take part of rehabilitation groups. 
The groups were submitted to 3 rehabilitation sessions, each of them lasting 1 hour. 33 workers participated of this stage.

The groups were reevaluated using HHIA.

Evocation technique of structural approach of Social Representations was employed as complementary evaluation instrument, submitted before and after group sessions.

It was concluded that the group had an outstanding role, providing a space to reflect on health-work-disease process, providing also information regarding noise and its impact on health.

In addition, the results revealed an increase in the perception of handicap, suggesting that the group was efficient regarding this point.

The analysis of evocations demonstrated that there was no changes in the occurrence in inductor terms representation (deafness, communication, deafness and work).

Individuals having normal hearing $(46,7 \%)$, as well as those having NIHL $(74 \%)$ were recorded with handicap perception.

This indicates a possible limitation of audiologic evaluation when employed to analyze the effects of noise, and the need to adequate, for example by the mean of an instrument of handicap perception evaluation.

The workers presented suggestions regarding improvement of the work environment and production process. 


\section{ÍNDICE}

1 INTRODUÇÃO

2 RUÍDO

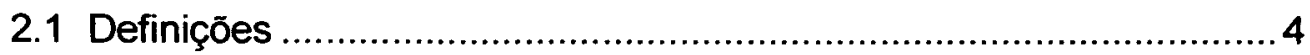

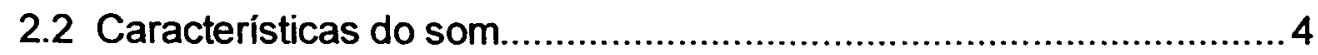

2.3 Classificação dos diferentes tipos de ruído ....................................... 5

2.4 Avaliação e controle de ruído ambiental .......................................... 6

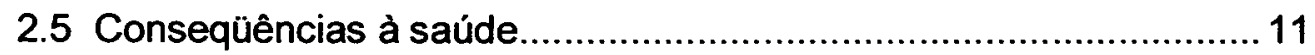

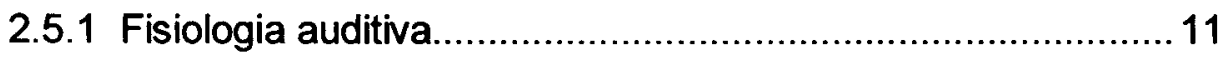

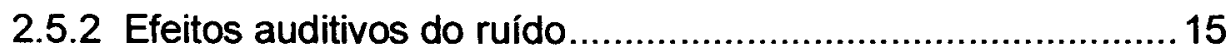

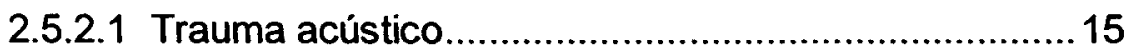

2.5.2.2 Mudança temporária de limiar (MTL) ........................ 16

2.5.2.3 Perda auditiva induzida por ruído (PAIR) .................. 17

2.5.2.4 Limitações auditivas funcionais .................................. 20

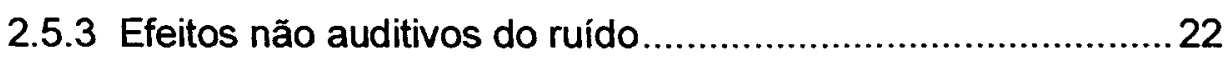

3 AÇŐES DE ATENÇÃO À SAÚDE AUDITIVA DO TRABALHADOR

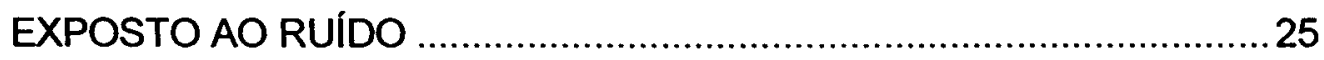

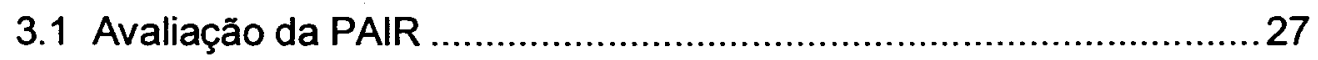

3.1.1 A avaliação dos efeitos auditivos da PAIR ...............................

3.1.2 Avaliação dos efeitos não auditivos da PAIR .........................32

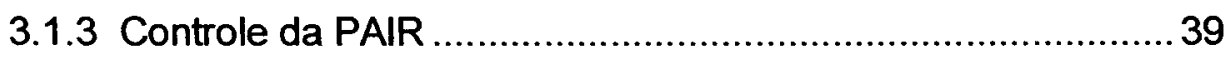

3.1.4 Reabilitação ……............................................................. 40

3.1.4.1 Definições ............................................................. 40

3.1.4.2 Estudos sobre reabilitação ....................................... 41

3.1.4.3 Método do trabalho de reabilitação auditiva do trabalhador exposto ao ruído .......................................45

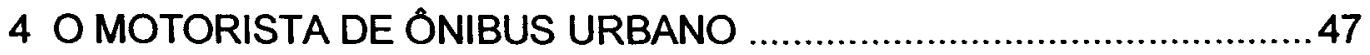

4.1 Histórico do transporte coletivo em São Paulo...................................47

4.2 Perfil dos motoristas de ônibus urbano de São Paulo.........................48

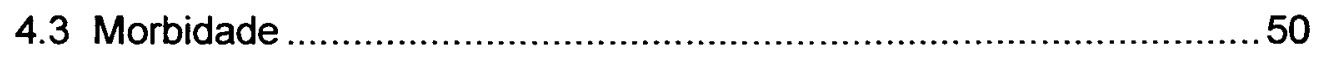

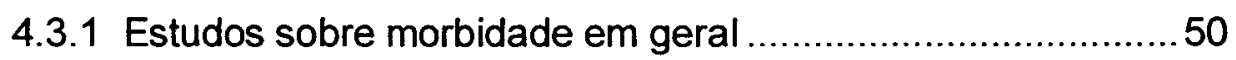

4.3.2 Estudos sobre alterações cárdio-circulatórias........................52 
4.3.3 Estudo sobre alteraçð̃es respiratórias..................................53

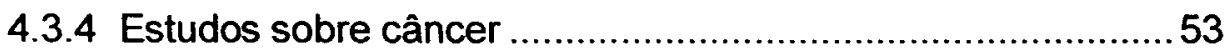

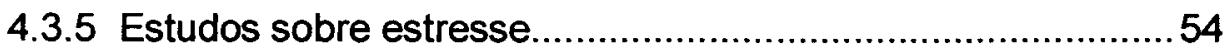

4.3.6 Estudos sobre ruído e perda de audição ...............................55

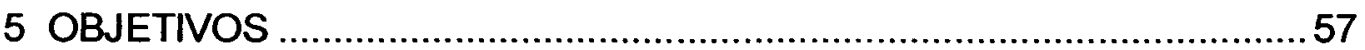

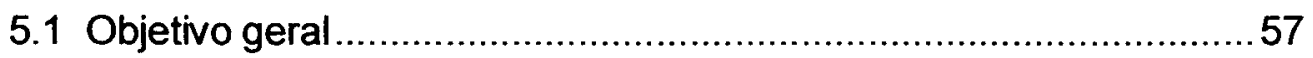

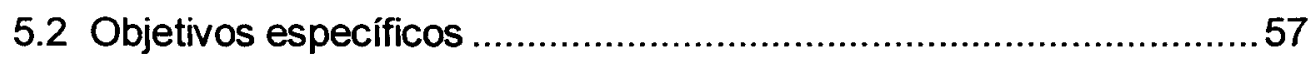

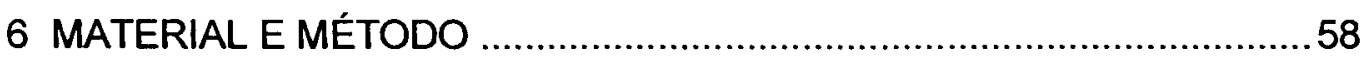

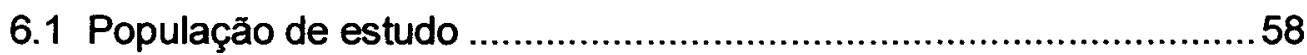

6.2 Procedimentos utilizados para a avaliação da população..................59

6.2.1 Avaliação da PAIR ..........................................................59

6.2.2 Avaliação das dificuldades de comunicação ...........................61

6.2.3 Identificação das representações sociais ..............................61

6.2.4 Método de intervenção educativo-terapêutica .......................62

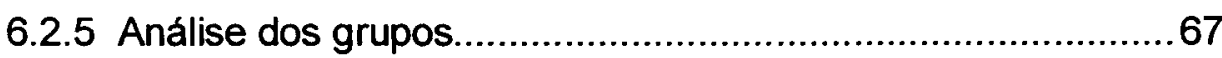

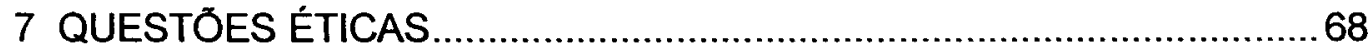

8 RESULTADOS

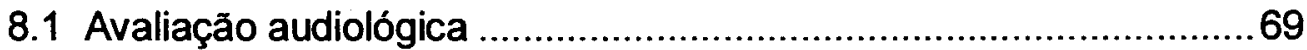

8.2 Avaliação da percepção de handicap ............................................ 72

8.3 Avaliação auditiva e avaliação da percepção de handicap ...............74

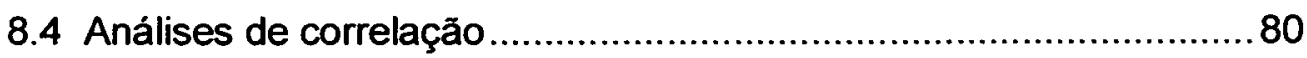

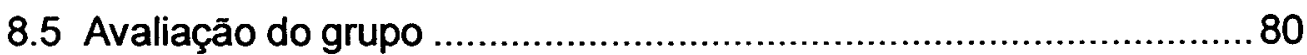

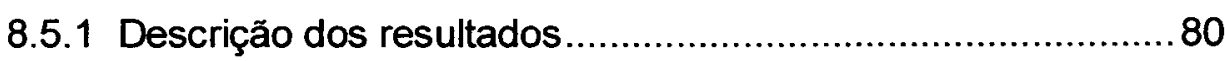

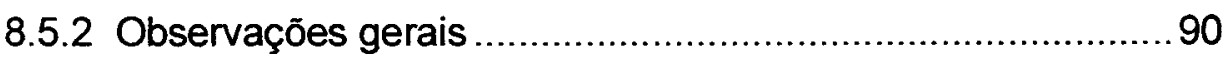

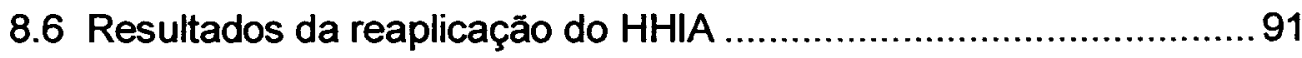

8.7 Resultados da análise das evocaçōes ...........................................92

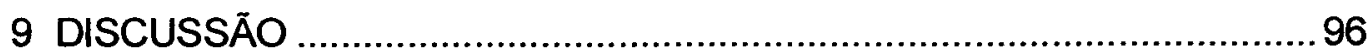

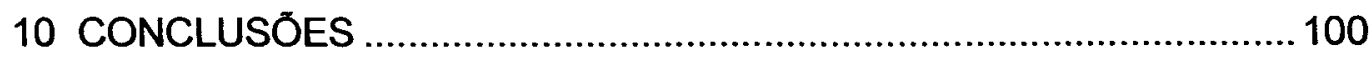

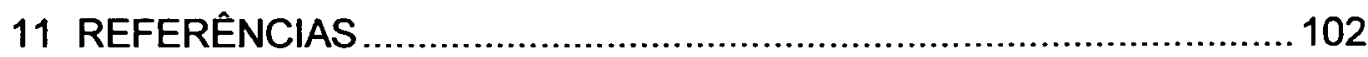

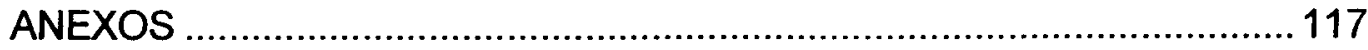




\section{TABELAS E FIGURAS}

Figura 1 - llustração gráfica das curvas isofônicas e do mínimo campo audivel para tons puros (Norma ISO 226:1987).

Figura 2: Curvas de compensação originadas pelos filtros de ponderação $A$, $\mathrm{B}$ e C.

Figura 3 - Estruturas da orelha.

Figura 4 - Orgão de Corti (Orgão Espiral)

Figura 5 - Comparação entre as idades do grupo AUDIÇÃO NORMAL e PAIR.

Figura 6 - Comparação do tempo de exposição dos grupos AUDIÇÃo NORMAL e PAIR.

Figura 7 - Comparação entre as idades da população estudada, dividida em sub-grupos.

Figura 8 - Comparação entre os resultados das aplicações do HHIA pré e pós grupos.

Tabela 1 - Limites de tolerância para ruído contínuo ou intermitente (NR-15)

Tabela 2 - Instrumentos de auto-avaliação para a verificação do handicap auditivo

Tabela 3 - Estudos e riscos auditivos

Tabela 4 - Distribuição da população estudada, segundo faixa etária.

Tabela 5 - Distribuição da população estudada, segundo tempo de exposição a ruído.

Tabela 6 - Conteúdo específico planejado

Tabela 7 - Distribuição da população estudada, segundo situação auditiva.

Tabela 8 - Distribuição do grupo PAIR, segundo grau de perda auditiva.

Tabela 9 - Distribuição da população estudada, de acordo com a situação auditiva, segundo faixa etária.

Tabela 10 - Distribuição da população estudada, de acordo com a situação auditiva, segundo tempo de exposição. 
Tabela 11 - Distribuição da população estudada, segundo percentual de percepção de handicap.

Tabela 12 - Distribuição da população estudada, por graus de percepção de handicap.

Tabela 13 - Distribuição da população com percepção de handicap, segundo grau

Tabela 14 - Distribuição da população estudada, por situação auditiva, segundo percepção de handicap.

Tabela 15 - Distribuição da população estudada, nos sub-grupos, segundo situação auditiva e percentual de handicap.

Tabela 16 - Distribuição da população estudada, dividida em sub-grupos, por faixa etária.

Tabela 17 - Distribuição das respostas obtidas pela população estudada, pré e pós grupo $(\mathrm{N}=825)$.

Tabela 18 - Termo indutor: SURDEZ - Pré-grupo

Tabela 19 - Termo indutor: SURDEZ - Pós-grupo

Tabela 20 - Termo indutor: SURDEZ E TRABALHO - Pré-grupo

Tabela 21 - Termo indutor: SURDEZ E TRABALHO - Pós-grupo 


\section{LISTA DE ABREVIATURAS}

$\mathrm{CPHI}$ - Communication Profile for the Hearing Impaired

DENVER SCALE - Denver Scale of Communication Function

DSCF - Denver Scale of Communication Function

HDHS - Hearing Disability and Handicap Scale

HHIA - Hearing Handicap Inventory for the Adults

HHIE - Hearing Handicap Inventory for the Elderly

HHS - Hearing Handicap Scale

HMS - Hearing Measurement Scale

HPI - Hearing Problem Inventory 


\section{INTRODUÇÃO}

A exposição prolongada a ruído excessivo provoca a Perda Auditiva Induzida pelo Ruído (PAIR), de característica irreversível e progressiva. A PAIR é uma doença bastante estudada e conhecida em vários aspectos; no entanto, seu controle ainda não é efetivo. Uma das dificuldades a ser enfrentada é o relativo desconhecimento de todas as conseqüencias da PAIR na vida de seu portador.

$\mathrm{Na}$ PAIR, observamos que sua etiologia é praticamente conhecida, mas suas conseqüências na vida do indivíduo, ainda foram pouco estudadas.

Vários estudos sobre a PAIR (FIORINI 2000; BERNARDI 2000) têm utilizado os avanços tecnológicos dos equipamentos de avaliação audiológica, que permitem um grau de detalhamento cada vez maior das alteraçōes ainda em fase subclínica, como uma forma de aprofundamento também sobre a própria fisiologia auditiva.

Há necessidade, porém, de uma maior compreensão sobre as dificuldades provocadas pela PAIR, para que seja possível atuar, de maneira mais completa, sobre essa importante patologia. HĖTU e col. (1995), apontam: dificuldades na percepção e/ou discriminação de sinais auditivos de aviso, dificuldade em localizaçăo da fonte sonora e dificuldade na comunicação verbal. Fora do ambiente de trabalho observa-se a restrição de atividades sociais e dificuldade nas interações familiares.

Esses aspectos deveriam ser contemplados tanto nos Programas de Conservaçăo Auditiva (PCA) a serem implantados nos ambientes de trabalho, como nos serviços de atenção à saúde do trabalhador. Entretanto, a adoção de programas de gerenciamento de risco auditivo ainda é prática recente nas empresas e, no SUS, as ações são direcionadas à vigilância sanitária e epidemiológica, restringindo a assistência à realização da avaliação audiológica. Por isso, podemos supor que exista um grande contingente de trabalhadores portadores de PAIR, em diferentes graus e com diferentes dificuldades, atuando dentro da empresa sem 
acompanhamento adequado, tendo que despender um maior esforço na realização de tarefas que envolvem a percepção e discriminação auditiva e correndo maiores riscos de acidentes. A eles se destina somente a piora de suas condições de audição e de saúde em geral, incluindo os efeitos de outras exposições relacionadas ao ruído urbano e também ao chamado "envelhecimento natural" da orelha, conhecido como presbiacusia (WEINSTEIN 1999).

Muitos trabalhadores nessas condições são demitidos e, o fato de não terem acesso a qualquer tipo de reabilitação, é um importante componente da sua impossibilidade de retornar ao mercado de trabalho.

Estudos têm tentado desenvolver métodos de avaliação das perdas auditivas do tipo neurossensorial como a PAIR, que considerem seus efeitos de uma forma mais global. Nos últimos anos, um grande número de instrumentos foi desenvolvido para avaliar as dificuldades desses indivíduos (GIOLAS 1999), pois a audiometria tonal e a logoaudiometria, como são realizadas na rotina clínica hoje, não fornecem todas as informações necessárias. Existem propostas de alterações na avaliação audiológica para que seja mais efetiva. Além disso, alguns questionários de auto-avaliação podem ser utilizados acoplados a anamnese ocupacional para que, pelo próprio discurso do trabalhador, também possamos nos aproximar da compreensão de suas dificuldades.

São essas reflexões que nos levam a pesquisar uma possível metodologia de reabilitação auditiva do trabalhador portador de PAIR, que possa ser incluída nos programas de prevenção de perdas auditivas das empresas e nos serviços de atenção à saúde do trabalhador. 


\section{RUÍDO}

O ruído já faz parte do nosso dia-a-dia. E isso se inicia cada vez mais cedo, pois pode-se observar, em gestantes que trabalham expostas a niveis elevados de ruído, e principalmente quando o trabalho é realizado em turnos, desde lesర̃es auditivas irreversiveis no feto (LALANDE e col. 1986), até problemas na gestação, como hipertensão, hiperemese gravídica, parto prematuro e bebês de baixo peso (NURMINEN e KURPPA 1989; NURMINEN 1995; HARTIKAINEN e col. 1994). Caso necessite de incubadora, o bebé ficará exposto a níveis de pressão sonora de aproximadamente $61 \mathrm{~dB}(\mathrm{~A})$, que podem atingir até 130 ou $140 \mathrm{~dB}(\mathrm{~A})$, de acordo com as manobras realizadas (BESS e col. 1979). Quando for para casa, o bebê, e depois a criança, terá ao seu redor brinquedos que podem atingir $100 \mathrm{~dB}$ (A) (CELANI e col. 1991) e eletrodomésticos que produzem ruidos de semelhante intensidade. Na escola, onde permanece em média 4 $\mathrm{h} / \mathrm{dia}$, o ruido pode atingir até $94,3 \mathrm{~dB}(\mathrm{~A})$, com a média $70 \mathrm{~dB}(\mathrm{~A})$ (CELANI e col. 1994; FRANÇA, 2000). Quando se tornar um adolescente, serão agregados a essa exposição seus hábitos de lazer (motocicleta, discoteca, walkman) e o ruído urbano.

Ao entrar na fase adulta, esse indivíduo poderá passar de 8 a 12 horas diárias, em média, exposto a elevados niveis de pressão sonora, em seu ambiente de trabalho.

Esse estilo de vida, nem sempre opcional, leva à incorporação do ruído a nossas vidas, como se fosse algo natural e, portanto, inofensivo. Esse comportamento, bastante nocivo à saúde, torna-se mais perigoso quando se trata de ruído no ambiente de trabalho, pela sua intensidade, tempo de exposição e efeitos combinados com outros fatores de risco, como produtos químicos ou vibração (SILVA 2002).

Para melhor analisar o risco, iremos definir ruído, sua forma de avaliação e controle, e seus efeitos sobre a saúde. 


\subsection{Definições}

A Acústica é um ramo da Física definida como a ciência que estuda o som, em relação à sua produção, transmissão e detecção. É dividida em Acústica Física, que trata das vibrações e ondas mecânicas, e Acústica Fisiológica ou Psicoacústica, relacionada à sensação que o som produz nos indivíduos (RUSSO 1993).

A partir dessa categorização, podemos apresentar as definições de som e ruído, pois ambos podem ser considerados tanto pelo aspecto acústico, como pelo psicoacústico.

O som é definido como qualquer perturbação vibratória em um meio elástico, que produza sensação auditiva (MERLUZZI 1981). O ruído é um sinal acústico aperiódico, originado da superposição de vários movimentos de vibração com diferentes freqüências, que não apresentam relação entre si (FELDMAN e GRIMES 1985). Portanto, do ponto de vista da Acústica Física, podemos dizer que a definição de ruído é englobada pela definição de som.

Em relação à psicoacústica, enquanto o som é utilizado para descrever sensações prazerosas, o ruído é usado para descrever sons indesejáveis ou desagradáveis, o que traz um aspecto de subjetividade à sua definiçāo.

\subsection{Características do som}

Freqüência é o número de ciclos por unidade de tempo (ciclos/segundo), medida em hertz $(\mathrm{Hz})$. O ouvido humano tem capacidade de captar sons entre 16 e $20.000 \mathrm{~Hz}$. Os sons abaixo desse intervalo (infrasons) e os sons acima dele (ultra-sons) não são audiveis (SANTOS e MATOS 1994).

Intensidade é a quantidade de energia vibratória que se propaga nas áreas próximas, a partir da fonte emissora. Pode ser expressa em energia (watt/m $\mathrm{m}^{2}$ ) ou pressão ( $\mathrm{N} / \mathrm{m}^{2}$ ou pascal). O ouvido humano percebe sons entre 
$0,00002 \mathrm{~N} / \mathrm{m}^{2}$ a $200 \mathrm{~N} / \mathrm{m}^{2}$. Como essa faixa é extremamente grande, o uso de uma escala linear poderia exigir tratar com números muito grandes ou muito pequenos, dispersos num campo entre 1 a $10^{12}$. Por isso, optou-se pela utilização de uma escala logarítmica, na qual, ao valor da grandeza em exame, se faça corresponder o logaritmo da relação entre aquele mesmo valor e um de referência (SILVA 1993). Utiliza-se, assim, o decibel (dB) para a faixa de intensidade audivel ao ser humano, que corresponde aos valores de zero a 120 dB NPS (Nível de Pressão Sonora).

Essas características são avaliadas no exame audiométrico, que informa sobre a situação auditiva do sujeito, normal ou alterada, em que grau, e qual a localização da lesão.

\subsection{Classificação dos diferentes tipos de ruído}

SANTOS e MATOS (1994) classificaram os ruídos da seguinte forma: 1 - Quanto ao espectro de freqüência

a) Espectro contínuo, no qual a energia sonora se distribui por uma grande parte das freqüências audíveis.

b) Espectro com poucos tons audiveis.

c) Espectro com predominio de poucas freqüências, que podem chegar a um tom puro.

d) Espectro com predomínio de altas ou baixas freqüências.

2 - Quanto à variação no tempo

a) Contínuo: ruído com pequenas variações ( $\pm 3 \mathrm{~dB}$ ), durante 0 período de observação.

b) Intermitente: ruído com variação maior ( $> \pm 3 \mathrm{~dB}$ ), durante o período de observação.

c) Impacto: ruído que se apresenta em picos de energia acústica de duração inferior a um segundo.

Essas informações sobre o ruído são de fundamental importância para avaliar as conseqüências sobre a saúde dos 
expostos, bem como para determinar as formas mais eficazes de controle ambiental.

\subsection{Avaliação e controle de ruído ambiental}

A avaliação ambiental de ruído é realizada sob a responsabilidade de um engenheiro ou técnico de segurança. Somente serão destacados aqui alguns passos essenciais dessa atividade.

A Norma Regulamentadora n.15 (NR-15), da Portaria n. 3.214, de 8 de junho de 1978, estabelece os limites de exposição a ruído contínuo, conforme a Tabela 1abaixo.

Tabela 1 - Limites de tolerância para ruído contínuo ou intermitente (NR-15)

\begin{tabular}{|c|c|}
\hline Nível de Ruido dB(A) & Máxima exposição diária permissivel \\
\hline 85 & 8 horas \\
\hline 86 & 7 horas \\
\hline 87 & 6 horas \\
\hline 88 & 5 horas \\
\hline 89 & 4 horas e 30 minutos \\
\hline 90 & 4 horas \\
\hline 91 & 3 horas e 30 minutos \\
\hline 92 & 3 horas \\
\hline 93 & 2 horas e 30 minutos \\
\hline 94 & 2 horas \\
\hline 95 & 1 hora e 45 minutos \\
\hline 98 & 1 hora e 15 minutos \\
\hline 100 & 1 hora \\
\hline 102 & 45 minutos \\
\hline 104 & 35 minutos \\
\hline 105 & 30 minutos \\
\hline 106 & 25 minutos \\
\hline 108 & 20 minutos \\
\hline 110 & 15 minutos \\
\hline 112 & 10 minutos \\
\hline 114 & 8 minutos \\
\hline 115 & 7 minutos \\
\hline
\end{tabular}


Observa-se que essa norma adota o fator de correção (exchange rate) $q$ igual a cinco, o que significa que a cada aumento de intensidade de 5 $\mathrm{dB}(\mathrm{A})$, a exposição deve ser reduzida pela metade. Na maioria dos países europeus, utiliza-se o fator de correção $q$ igual a três, ou seja, a exposição deve ser reduzida pela metade a cada incremento de $3 \mathrm{~dB}(\mathrm{~A})$ no nível de pressão sonora. Esse fator de correção é adotado pela relação entre a perda auditiva e o tempo de exposição.

Outra importante consideração é que essa tabela é apenas indicativa, dadas as características subjetivas da sensibilidade ao ruído. Isso significa ser perfeitamente possivel a existência de perdas auditivas com exposição dentro dos limites preconizados pela NR-15.

O limite de tolerância para ruído do tipo impacto será de $130 \mathrm{~dB}(\mathrm{~A})$, de acordo com a NR-15. Nos intervalos entre os picos, o ruído existente deverá ser avaliado como ruído contínuo.

O objetivo da avaliação de ruído é caracterizar a exposição de todos os trabalhadores sob risco. Para isso, é fundamental que primeiro seja feita uma detalhada observação do processo produtivo, por meio da qual serão localizados os pontos de maior risco auditivo (considerando-se também número e idade dos expostos), o tipo de ruído, as características da função e os horários de maior ritmo de produção. Essas informações são obtidas pela observação direta, levantamento de documentação da empresa e conversa com os trabalhadores.

GIAMPAOLl e col. (1999) afirmam que a avaliação deve cobrir todas as condições operacionais e ambientais habituais que envolvem 0 trabalhador, no exercício de suas funçōes.

Após essa primeira etapa, deve ser determinada a metodologia de avaliação, da qual faz parte a definição dos instrumentos a serem utilizados, o período avaliado e os horários mais significativos.

Os instrumentos utilizados na avaliação são o medidor de nivel de pressão sonora e o dosímetro de ruído ou medidor integrador de uso pessoal. 
O medidor de nível de pressão sonora registra de forma direta o nível de pressão sonora de um fenômeno acústico. Ele expressa o resultado em $\mathrm{dB}$, com uma pressão sonora de referência de $2 \times 10^{-5}$ pascal. Esse instrumento é dotado de filtros de ponderação para freqüências e circuitos de respostas. Os filtros de ponderação têm a finalidade de aproximar a medição efetuada das características perceptíveis pelo ouvido humano. Eles se baseiam nas curvas isofônicas, que demonstram como a sensibilidade auditiva se caracteriza, não sendo igual para todas as freqüências, e tendo em torno de $1.000 \mathrm{~Hz}$ a maior correspondência entre o som emitido e a sua percepção, conforme demonstra a Figura 1.

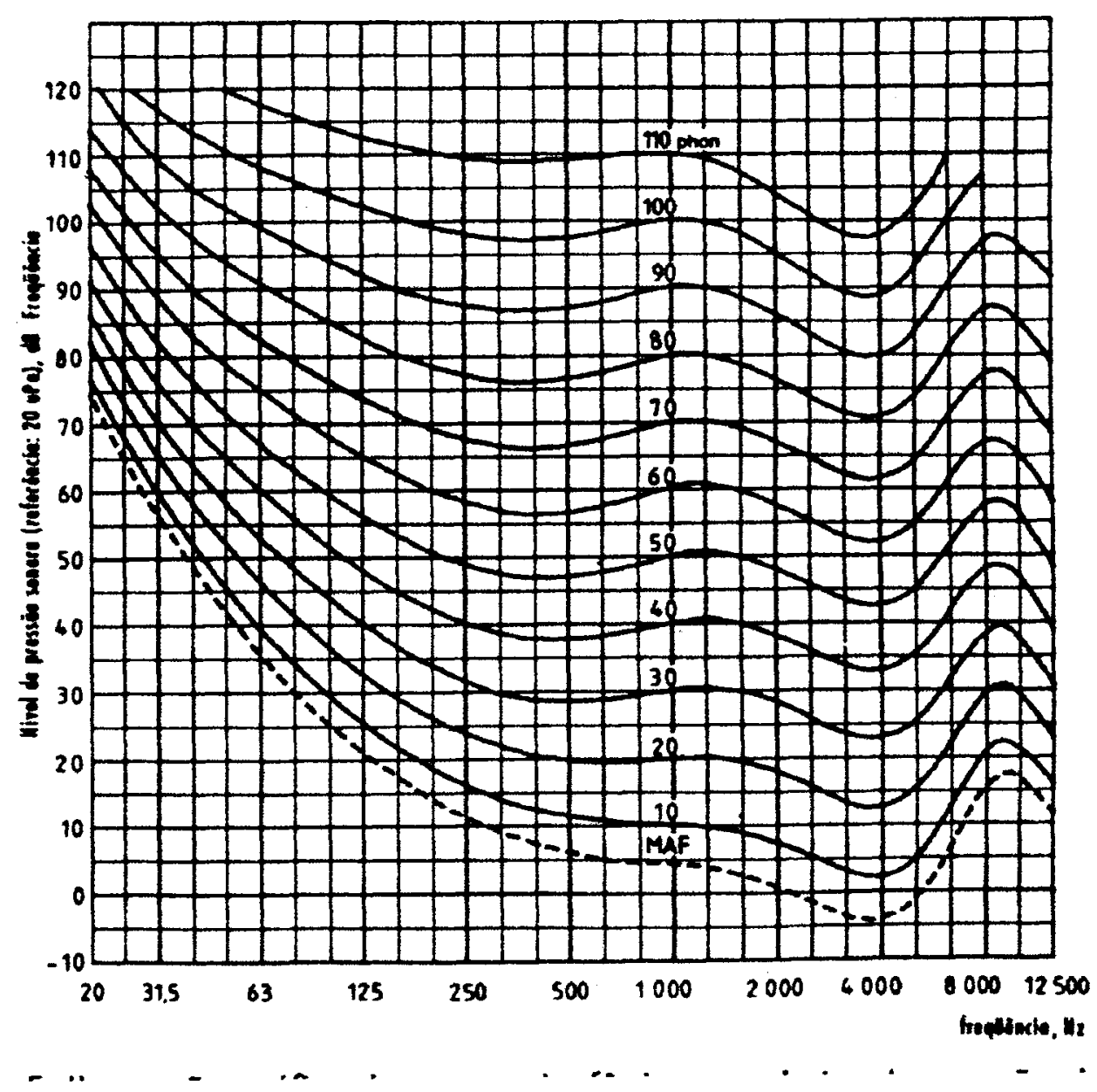

Figura 1 - llustração gráfica das curvas isofónicas e do mínimo campo audível para tons puros (Norma ISO 226:1987). (SANTOS e MATOS 1994 
Existem quatro tipos de filtros de ponderação: $A, B, C$ e D. Geralmente, utiliza-se o tipo A, por apresentar resposta mais semelhante ao do ouvido humano. Na Figura 2, são apresentadas as curvas de compensação originadas pelos filtros de ponderação $A, B$ e C.

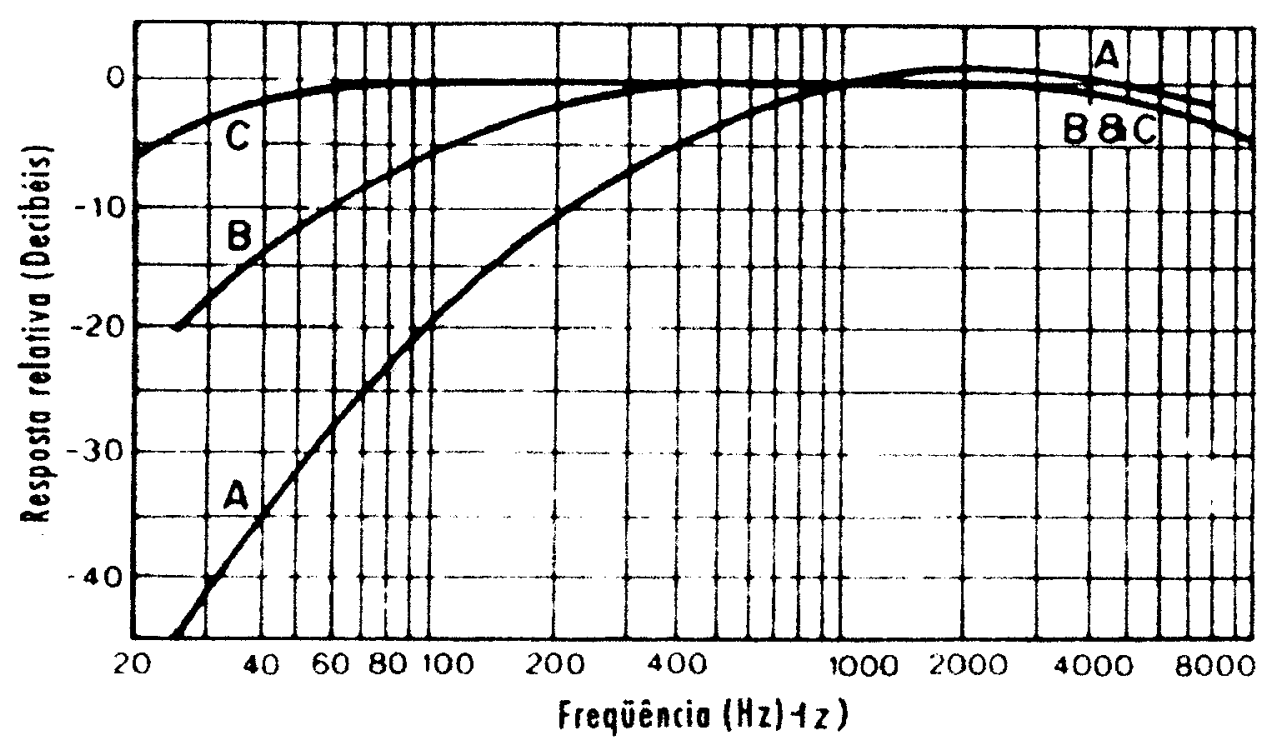

Figura 2 - Curvas de compensação originadas pelos filtros de ponderação A, B e C. (SANTOS e MATOS 1994)

Ainda de acordo com a NR-15, os níveis de ruído contínuo ou intermitente devem ser medidos em decibéis, com instrumento de nível de pressão sonora operando no circuito de resposta lenta (slow), na curva de compensação A. O ruído de impacto deve ser avaliado com o medidor de nível de pressão sonora operando no circuito linear e de resposta para impacto, com o limite de tolerância estabelecido em $130 \mathrm{~dB}$ (linear). Quando o equipamento não dispõe de circuito linear, utiliza-se o circuito de resposta rápida (fast), na curva de compensação C. Nesse caso, o limite de tolerância é de $120 \mathrm{~dB}$.

O dosímetro de ruído é um monitor de exposição que acumula o ruído constantemente, expressando seu resultado em dose. Ele será ajustado 
para que a dose diária permitida, $85 \mathrm{~dB}$ por 8 horas, seja considerada como $100 \%$.

Por ser menor, acomodado à roupa do trabalhador, é o mais indicado para funções que requerem movimentação do trabalhador ou quando há muita variação de exposição durante a jornada, como é o caso dos motoristas de ônibus.

GIAMPAOLI e col. (1999) recomendam que o relatório técnico final da avaliação contenha, no mínimo, os seguintes aspectos: introdução, incluindo os objetivos do trabalho, justificativa e período em que foram desenvolvidas as avaliações, critério de avaliação adotado, instrumental utilizado, metodologia de avaliação, descrição das condições de exposição avaliadas, dados obtidos e interpretação dos resultados.

A partir desse relatório e dos dados obtidos na avaliação biológica, serão determinados os locais, máquinas ou pontos do processo produtivo prioritários para a redução do ruído.

O controle de ruído deve seguir etapas (SANTOS e MATOS 1994), de acordo com a maior benefício para o trabalhador. Essas etapas são:

1 - Intervenção sobre a fonte emissora, por meio da eliminação ou substituição por máquina mais silenciosa, modificação no ritmo de funcionamento da máquina ou aumento da distância e redução da concentração de máquinas no ambiente.

2 - Intervenção sobre a trajetória do ruído, de forma a impedir o alcance do ruido excessivo sobre o trabalhador, por meio da utilização de suportes antivibratórios, enclausuramento parcial ou total da máquina, colocação de barreiras, colocação de silenciadores ou aplicação de tratamento fonoabsorvente.

3 - Intervenção sobre o sujeito exposto. Quando as etapas citadas anteriormente não são viáveis, pelo menos a curto prazo, pode-se optar pela adoção de isolamento do trabalhador em cabine silenciosa, redução do tempo de exposição, com revezamento, por exemplo, e utilização de protetor auditivo. 
Embora, aparentemente, a utilização de protetores auditivos seja a medida de menor custo e de maior facilidade de adoção, não deve ser aplicada de forma isolada, pois não terá o efeito esperado.

FIORINI e NASCIMENTO (2001) apontam que a proteção individual deve obedecer às seguintes etapas: homologação, que significa cuidados com a qualidade do protetor, as fontes de ensaio que garantem a atenuação, o conforto proporcionado pelo protetor, testes de aceitação por parte dos usuários e custos de reposição; testes e definição do protetor adequado à função e à exposição; orientação; troca e acompanhamento do uso.

A indicação do protetor auditivo deve, portanto, ser feita com extremo cuidado, considerando-se a função do trabalhador, se há exigência de comunicação oral, se há excessivo calor, se ele deve se movimentar por locais pequenos ou estreitos; a condição auditiva do trabalhador, desde a conformação do meato acústico externo, existência de alterações de orelha média e existência de perda auditiva que possa comprometer sua segurança, quando do uso de protetor auditivo.

\subsection{Consequiências à saúde}

\subsubsection{Fisiologia auditiva}

Para compreender a fisiopatologia auditiva provocada pela exposição ao ruído, é necessário primeiramente conhecer seu funcionamento normal, ou seja, sua fisiologia.

O sistema auditivo está contido no osso temporal e é constituído por orelha externa, orelha média, orelha interna e vias auditivas. Tem como funções principais a audição e o equilíbrio. Na Figura 3 vemos as estruturas da orelha. 


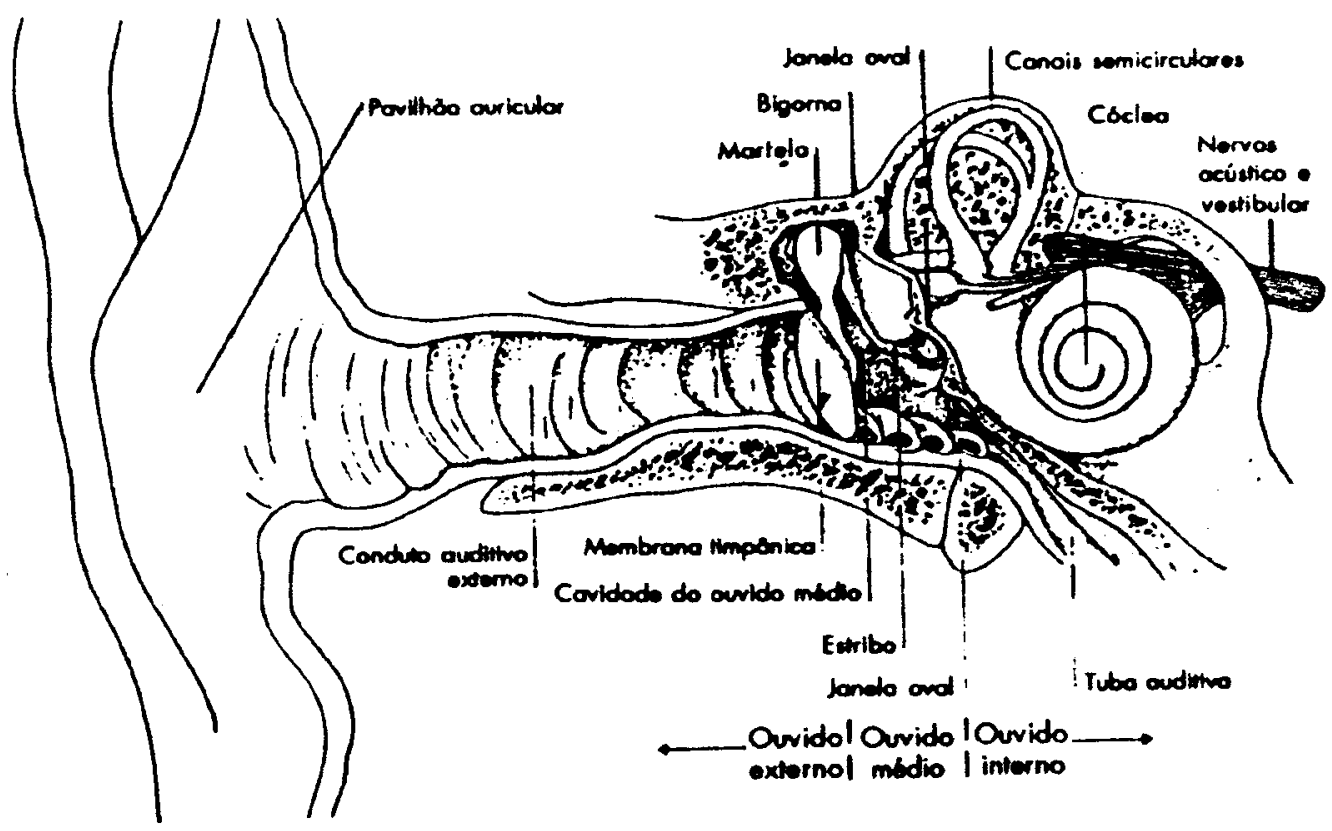

Figura 3 - Estruturas da orelha. (SANTOS e MORATA 1994)

O som é captado pelo pavilhão auricular e direcionado à orelha média. O pavilhăo auricular é responsável por um acréscimo de sete a 10 $\mathrm{dB}(\mathrm{A})$ na faixa de freqüência de $2 \mathrm{k}$ a $5 \mathrm{kHz}$. Além disso, ele contribui para a localização da fonte sonora, assim como para a discriminação de modificaçōes na intensidade do som.

Para alcançar a orelha média, o som passa pelo meato acústico externo, que é um canal cilíndrico, de aproximadamente $27 \mathrm{~mm}$, recoberto por pele, possuindo pêlos e glândulas produtoras de cera, que têm o objetivo de proteger a membrana timpânica contra corpos estranhos e modificações de temperatura e umidade. A forma desse conduto também amplifica frequeências na faixa de $3 \mathrm{kHz}$ (SANTOS e MORATA 1994) ou de 1,5 a 7 $\mathrm{kHZ}$ (MUNHOZ e col. 2000a).

A orelha média é uma cavidade com 1 a $2 \mathrm{~cm}^{3}$, que se inicia a partir da membrana timpânica. Essa membrana é ligada a uma cadeia de ossículos (os menores do corpo humano), denominada cadeia ossicular, suspensa por uma série de ligamentos e cuja base está inserida em um 
orifício da orelha interna denominado janela oval. Quando o som estimula a membrana timpânica, provoca a movimentação da cadeia ossicular, que irá estimular a movimentação de líquidos da orelha interna. A cadeia ossicular atua como um transformador mecânico de energia, que recupera e amplifica a energia sonora perdida na passagem do meio aéreo (orelha média) para o meio líquido (orelha interna).

A orelha interna é composta pelo vestíbulo, pelos canais semicirculares e pela cóclea. O vestíbulo e os canais semicirculares são responsáveis pelo equilíbrio, enquanto a cóclea, pela audição.

A cóclea tem o aspecto de uma concha de caracol. Ela é um labirinto ósseo que contém um labirinto membranoso (MUNHOZ e col., 2000a). Ela também é definida como um sistema de três canais enrolados, denominados escala vestibular, média (ducto coclear) e timpânica. Internamente a esses canais, existe perilinfa (nas escalas vestibular e timpånica) e endolinfa (no ducto coclear). O ducto coclear e a escala vestibular estão separadas pela membrana de Reissner e o ducto coclear e a escala timpânica pela membrana basilar. É sobre essa membrana que se localiza o órgão de Corti (órgão espiral). Esse órgão possui células ciliadas denominadas externas (células ciliadas externas) e internas (células ciliadas internas).

As células ciliadas externas são em número de 10.000 a 14.000 , têm forma cilíndrica e estão dispostas em três fileiras sobre a membrana basilar do canal coclear. Essas células são envolvidas parcialmente pelas células de sustentação, formando, entre elas, os espaços de Nuel, o que permite seu movimento. Cada célula apresenta dezenas de cílios, em três fileiras, com diferentes alturas; os cílios mais internos são mais curtos e os mais externos são mais longos e implantados na membrana tectória. São inervadas, predominantemente por fibras eferentes.

As células ciliadas internas são em número aproximado de 3.500 , dispondo-se em uma só fileira sobre a membrana basilar. Essas células são totalmente envolvidas pelas células de sustentação, não havendo espaços entre elas. Os cílios das células ciliadas internas não alcançam a membrana 
tectória. São inervadas, predominantemente por fibras aferentes (OLIVEIRA 1997).

Na Figura 4, temos a representação desse órgão.

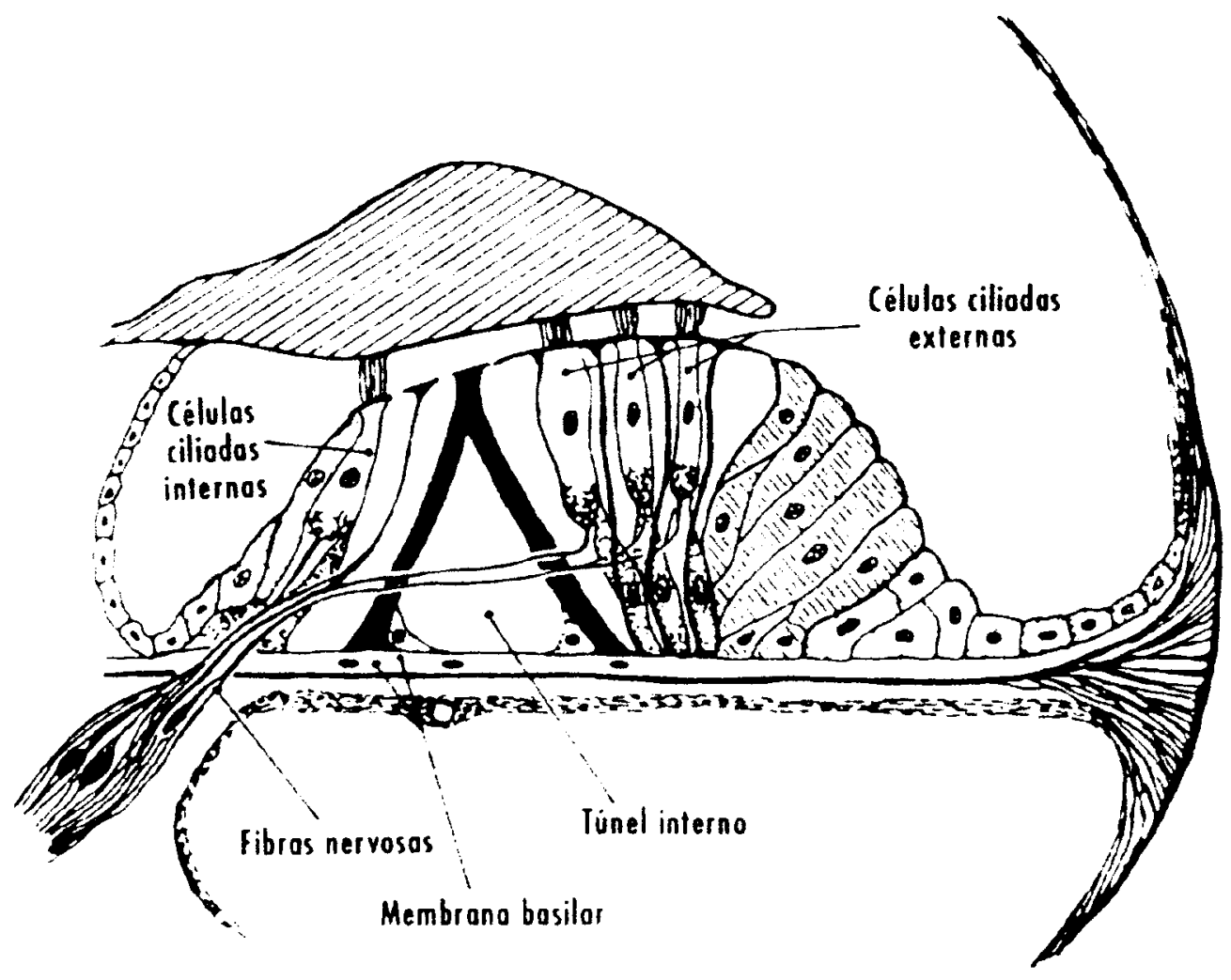

Figura 4 - Órgão de Corti (Órgão Espiral)

É na orelha interna que a vibração mecânica se transforma em energia elétrica e estimulação nervosa, que produzirá a sensação auditiva.

A energia sonora, do tipo mecânica, encaminhada pela orelha média, é transformada em pressão hidráulica dentro da cóclea, cheia de fluidos. A movimentação de líquidos sobre a membrana basilar provoca o deslocamento dos cilios das células ciliadas externas, que estão acoplados à membrana tectória. Os deslocamentos das membranas basilar e tectória, em padrões diferentes, provocam o aparecimento de forças tangenciais sobre os cílios das células ciliadas externas, provocando sua inclinação e 
conseqüente abertura de canais de potássio, que originarão contrações mecânicas rápidas das células ciliadas externas. Essas contraçōes amplificam as vibrações da membrana basilar e tectória, fazendo com que os cílios mais longos das células ciliadas internas entrem em contato com a membrana tectória e se inclinem. Essa inclinação permite a entrada de potássio, que provoca a despolarização das células ciliadas internas e estimula as terminações nervosas da via aferente. Esse mecanismo ocorre em grupos bem delimitados de células ciliadas internas, o que é a base da fina seletividade de freqüências.

É na orelha interna que ocorrem as principais lesões provocadas pela exposição ao ruído, que serão descritas a seguir.

\subsubsection{Efeitos auditivos do ruído}

\subsubsection{Trauma acústico}

É uma perda auditiva súbita, decorrente de uma única exposição a ruído intenso (HUNGRIA 1995). Sendo uma lesão mecânica, acarreta alteraçōes circulatórias no nível dos capilares da cóclea, traduzidas por empilhamento de hemácias, edema do endotélio e reação inflamatória perivascular. O empilhamento de hemácias provoca uma diminuição do fluxo sangüíneo e conseqüente aumento da viscosidade sangüínea, o que afeta a estria vascular, com prejuizo das células ciliadas do órgão de Corti (órgão espiral).

Quando ocorre uma explosão, a descompressão brusca e violenta pode acarretar dor e lesões simultåneas da orelha média, como rotura da membrana timpânica e/ou desarticulação dos ossículos, assim como distúrbios vestibulares (vertigem e perturbações de equilibrio). Nesse caso, o som chegará com menor energia na orelha interna, lesando menos essa região.

Geralmente, a intensidade sonora capaz de provocar trauma acústico é de 120 dBNA ou 140 dBNPS, tendo como origem explosões de fogos de 
artificios, disparos de armas de fogo, ruído de motores a explosão e alguns tipos de máquinas de grande impacto.

O elemento causador dessa perda auditiva é, geralmente, muito traumático e a pessoa envolvida não tem dificuldade em especificar o início do problema auditivo.

Normalmente, além da perda auditiva que é percebida de imediato, o paciente costuma relatar a presença de zumbido. Pode ocorrer uma melhora dos sintomas, após alguns dias. É recomendável a realização de avaliação audiológica, imediatamente após ocorrido o trauma, com repetição em intervalos aumentados, até a observação da estabilização do quadro audiológico.

\subsubsection{Mudança temporária de limiar (MTL)}

Também conhecida como TTS (Temporary Treshold Shift), é uma elevação do limiar de audibilidade que se recupera gradualmente, após a exposição ao ruido (SANTOS e MORATA 1994).

As variações na MTL ainda são controversas, mas de maneira geral, observa-se que:

1 - Os ruídos de alta freqüência são mais nocivos que os de baixa freqüência, principalmente na faixa entre $2 \mathrm{kHz}$ a $6 \mathrm{kHz}$.

2 - A MTL começa a partir de uma exposição a $75 \mathrm{~dB}(\mathrm{~A})$ e, acima desse nível, ela aumentará proporcionalmente ao aumento de intensidade e de duração do ruído.

3 - A exposição contínua é mais nociva do que a interrompida.

4 - A suscetibilidade individual segue uma distribuição normal.

Segundo MERLUZZI (1981), a recuperação dos limiares auditivos tem um andamento proporcional ao logaritmo do tempo, sendo que a maior parte da MTL é recuperada nas primeiras duas a três horas. $O$ restante da recuperação pode levar até 16 horas para se completar, dependendo da intensidade do estímulo. 
São observadas discretas alteraçōes intracelulares, edema das terminaçōes nervosas junto às células ciliadas, alteraç̋̄es vasculares, químicas e exaustão metabólica, além da diminuição da rigidez dos estereocílios, que ocasionam uma redução na capacidade das células em perceberem a energia sonora que as atingem (SANTOS e MORATA 1994). Essas alteraçōes podem ser reversíveis, de acordo com o tempo e a intensidade da exposiçăo.

A fadiga auditiva dessas estruturas pode ser considerada anormal quando a mudança de limiar permanece por mais de 16 horas, após o término da exposição.

\subsubsection{Perda auditiva induzida por ruido (PAIR)}

É uma perda auditiva do tipo neurossensorial, geralmente bilateral, irreversível e progressiva com o tempo de exposição ao ruído.

A maior característica da PAIR é a degeneração das células ciliadas do órgão de Corti (órgão espiral). SULKOWSKI (1980) sugere que, inicialmente, são afetadas as células ciliadas externas, seguidas pelas células ciliadas internas e, depois, pelas de sustentação.

As lesões das células ciliadas são descritas como o desalinhamento, fusão ou desaparecimento dos cílios, formação de cílios gigantes, mais longos e mais espessos e deformação das placas cuticulares. A perda das células ciliadas externas tem um pequeno efeito na degeneração de neurônios aferentes, mas induz uma grande degeneração nos eferentes. Portanto, só quando as células ciliadas internas forem atingidas ocorrerá uma substancial degeneração das fibras nervosas. Isso ocorre porque aproximadamente $95 \%$ dos neurônios aferentes do VIII par craniano se comunicam com as células ciliadas internas. BOHNE (1976) sugere que 0 evento crítico para as lesões das fibras nervosas seria a ocorrência de lesão nas células de suporte. No entanto, primária ou secundariamente, mudanças, mesmo que reversíveis, podem ser observadas nas fibras nervosas que fazem sinapse com as células ciliadas, sem a completa 
degeneração do órgão auditivo, ou mesmo eventual perda das células ciliadas.

É muito provável que, quando as células ciliadas externas forem atingidas, o feedback que elas realizam no órgão de Corti (órgão espiral) ficará afetado. Isso pode aumentar a suscetibilidade das células ciliadas internas e das estruturas que as cercam, a lesões por hiperestimulação (KRYTER 1985).

Um fato importante na identificação do problema é que a audiometria tonal pode não ser eficaz na detecção das lesões histopatológicas iniciais. Perdas de até $50 \%$ de células ciliadas externas, nas regiões apicais, podem se correlacionar com limiares tonais entre 10 e $15 \mathrm{~dB}(\mathrm{NA})$. A mesma lesão nos giros basais costuma proporcionar queda do limiar para 65-75 dB(NA).

DUNN (1987) afirmou que as alterações auditivas provocadas pelo ruído são resultado de lesão mecânica, metabólica, ou ambas. Acredita que o metabolismo das células sensoriais não se altere, enquanto existir reserva de glicogênio. Inicialmente, com a hiperestimulação provocada pelo ruído, ocorre um aumento da atividade metabólica das células sensoriais, que acarreta uma exaustão enzimática e dos estoques energéticos celulares, com hipoxigenação no ducto coclear e lesão, ainda reversivel, das organelas intracelulares.

Os resultados das avaliações eletrofisiológicas do microfonismo coclear (corrente elétrica proveniente da cóclea) apontam para o seu decréscimo, fenômeno observado nos casos de escassez de oxigênio, o que indica a importância da anóxia na ocorrência de alterações metabólicas e estruturais, causadas à orelha interna pelo ruído, levando a uma deficiência auditiva irreversível.

Em relação ao processo mecânico da lesão, LIM e DUNN (1979) apresentam algumas hipóteses:

i) Movimentação brusca dos fluidos na cóclea, causando ruptura na membrana de Reissner, com mistura de endolinfa e perilinfa e lesão das células sensoriais. 
ii) Movimentação brusca da membrana basilar, causando ruptura da lâmina reticular do órgão de Corti (órgão espiral). Haveria mistura de endolinfa e perilinfa, cuja modificação iônica lesaria as células ciliadas.

iii) Movimentação brusca dos fluidos da cóclea, que atingiria diretamente as células ciliadas, separando o órgão de Corti (órgão espiral) da membrana basilar ou rompendo a membrana basilar.

iv) A separação da membrana tectória dos cilios das células sensoriais, como resultado de hiperestimulação.

Quanto à localização da lesão, na porção basal da membrana basilar, há algumas hipóteses que pretendem justificá-la. HILDING (1953), após estudos anatômicos, observou que, pela configuração do canal coclear, pode existir um ponto de maior impacto nas estruturas que estão localizadas entre 6 a $8 \mathrm{~mm}$ da janela oval. CHADWICK (1971) afirmou que o suprimento sangüíneo da cóclea é deficiente na região dos $4 \mathrm{kHz}$ da membrana basilar (anatomia vascular) e que uma hipóxia afetaria primeiro essa região. GILCARCEDO Y GARCIA (1980) observam que a porção basal é a mais freqüentemente estimulada, uma vez que ela vibra, em diferentes padrões, para todas as frequêencias. Além disso, essa região é mais firme e rigidamente fixada à janela oval, o que a torna mais suscetivel a torçס̃es e à degeneração. CAIAZZO e TONDORF (1977) apontam que a ressonância da orelha externa pode acrescentar 15 a $20 \mathrm{~dB}(\mathrm{NPS})$ nas freqüências entre $3 \mathrm{e}$ $4 \mathrm{kHz}$ ao som que chega à membrana timpânica, o que causa maior estresse nessa região.

As características da PAIR são (COMITÉ NACIONAL DE RUIDO E CONSERVAÇÃO AUDITIVA 1999; FERREIRA JÚNIOR 1998):

i) Ser sempre neurossensorial, uma vez que a lesão é no órgão de Corti (órgão espiral) da orelha interna.

ii) Ser geralmente bilateral, com padrões similares. Em algumas situaçōes, observa-se diferenças entre os graus de perda das orelhas. iii) Geralmente, não produzir perda maior que $40 \mathrm{~dB}(\mathrm{NA})$ nas freqüências baixas e que $75 \mathrm{~dB}(\mathrm{NA})$ nas altas (Deve-se enfatizar, 
entretanto, que esses dados são obtidos de populações estrangeiras, devendo ser considerados com cautela, uma vez que não há dados específicos sobre o perfil audiométrico da população brasileira com PAIR).

iv) A sua progressão cessa com o fim da exposição ao ruído intenso.

v) A presença de PAIR não torna a orelha mais sensivel ao ruído; à medida que aumenta o limiar, a progressão da perda se dá de forma mais lenta.

vi) A perda tem seu inicio e predomínio nas freqüências de 3, 4 ou 6 $\mathrm{kHz}$, progredindo, posteriormente para 8, 2, 1, 0,5 e 0,25 kHz.

vii) Em condições estáveis de exposição, as perdas em 3,4 ou $6 \mathrm{kHz}$, geralmente atingirão um nível máximo, em cerca de 10 a 15 anos.

viii) O trabalhador portador de PAIR pode desenvolver intolerância a sons intensos, queixar-se de zumbido e de diminuiçāo de inteligibilidade da fala, com prejuízo da comunicação oral.

\subsubsection{Limitações auditivas funcionais}

As limitações funcionais apontadas por diversos autores (MCSHANE e col. 1988; MACRAE 1992; BERGMAN e col. 1992; HETU 1994; HËTU e TRAN QUOC 1996) referem-se à alteração da sensibilidade auditiva, da seletividade de freqüência, das resoluções temporal e espacial, ao recrutamento e ao zumbido.

A alteração da sensibilidade auditiva pode ser observada, parcialmente, por meio dos resultados da avaliação audiológica básica (audiometria tonal liminar e logoaudiometria). No entanto, é necessário saber como e se o trabalhador vivencia algum tipo de dificuldade, nas suas atividades de vida diária, o que demandaria algum outro tipo de avaliação como, por exemplo, questionários de auto-avaliação.

A seletividade de freqüência fica alterada pela lesão das células ciliadas, que provoca alargamento de banda dos filtros auditivos, existentes 
na membrana basilar, associando-se aos limiares auditivos elevados e provocando dificuldades na discriminação auditiva.

Da mesma forma, essa lesão provoca aumento do tempo mínimo requerido para resolver um evento sonoro (resolução temporal), o que, principalmente associado com a reverberação dos ambientes de trabalho, provoca limitação da capacidade do portador de PAIR em reconhecer sons (BAMFORD e SAUNDERS 1991).

HETU (1994) observa que a resolução espacial não tem sido considerada nas indústrias, locais onde o lay-out e o material que recobre as paredes pode influenciar muito no reconhecimento (identificação correta do estímulo sonoro, por meio de conhecimento anterior, previamente adquirido) e na discriminação auditiva (capacidade de diferenciação entre sons distintos, mesmo que acusticamente similares). Além disso, a utilização de protetores auditivos sem cuidados específicos, pode piorar ainda mais esse quadro.

Quando o indivíduo é portador de uma PAIR, que tem como característica ser neurossensorial, ocorre uma redução na faixa dinâmica entre o limiar auditivo e o limiar de desconforto, provocando um aumento na ocorrência de recrutamento (fenômeno de crescimento rápido e anormal da sensação de intensidade sonora) e, portanto, um aumento da sensação de desconforto. Isso é comum nos ambientes de trabalho com elevados níveis de pressão sonora.

O zumbido é um dos sintomas mais comumente relatados pelos portadores de PAIR, e provoca muito incômodo. Ele é definido como sendo a manifestação do mau funcionamento, no processamento de sinais auditivos envolvendo componentes perceptuais e psicológicos (VESTERAGER 1997). Num estudo com 3.466 trabalhadores requerentes de indenização por PAIR, McSHANE e col. (1988) observaram uma prevalência de zumbido de 49,8\%. Destes, $29,2 \%$ afirmaram que o zumbido era o problema principal.

As dificuldades de compreensão de fala são as mais relatadas pelo trabalhador portador de PAIR, cujo padrão de fala poderá sofrer alterações, de acordo com o grau de perda auditiva. 


\subsubsection{Efeitos não auditivos do ruído}

O ruído certamente não é o único fator presente no ambiente de trabalho capaz de desencadear efeitos nocivos à saúde em geral, como nervosismo, irritabilidade, cefaléia, insônia, entre outros apontados como efeitos não auditivos.

Considerando o ruído como um fator de estresse, fica mais fácil a compreensão da sintomatologia apresentada.

O estresse é definido por SELYE (1936), como sendo uma "resposta não específica do corpo a qualquer exigência feita sobre ele; é o conjunto de defesas do corpo contra qualquer forma de estimulo nocivo. Portanto, estresse não é doença e sim tentativa de adaptação (reação de luta ou fuga)".

Os fatos em si não são estressantes, é a forma como cada indivíduo interpreta e reage a eles que os torna estressantes. Por isso, o estresse depende da relação entre a pessoa e o ambiente, que pode estar sobrecarregando ou excedendo os seus recursos e ameaçando o seu bem estar.

A sintomatologia do estresse é dividida em três etapas: na primeira, chamada de reação de alarme, observa-se aumento de pressão sangüínea, de freqüência cardiaca e respiratória e diminuição da taxa de digestão; na segunda etapa, chamada de reação de resistência, o corpo começa a liberar estoques de açúcar e gordura, esgotando seus recursos, o que provoca cansaço, irritabilidade, ansiedade, problemas de memória e surgimento de doenças agudas como gripes; na terceira etapa, a da exaustão, os estoques de energia são esgotados, tornando o indivíduo cronicamente estressado, observando-se, então, insônia, erros de julgamento, mudanças de personalidade, doenças crônicas coronarianas, respiratórias, digestivas, mentais e outras (STILLMAN e DAWN 1975).

São definidos como estressores psicossociais do ambiente de trabalho:

i) Sobrecarga quantitativa: muito a fazer; excessiva pressão de tempo. 
ii) Sobrecarga qualitativa: conteúdo da tarefa muito limitado; ausência de variações no trabalho; baixa demanda de criatividade; poucas oportunidades de interação social.

iii) Ausência de controle sobre o ambiente e sobre a organização do trabalho.

iv) Ausência de suporte social: relações inadequadas no trabalho e em casa.

Portanto, podemos concluir que, como o ruído é um agente de risco, potencialmente estressor, pode trazer, como efeitos nocivos à saúde, não só os auditivos, mas toda uma gama de sintomatologia relacionada ao estresse, e que faz parte dos chamados efeitos não auditivos.

Dentro desses efeitos, é fundamental neste estudo esclarecer melhor aqueles relacionados à comunicação, que se caracteriza tanto como uma das conseqüências da lesão auditiva, podendo ser, também, diretamente um fator de estresse.

De acordo com os estudos de HÈTU e col. (1987), o trabalhador apresenta, como conseqüências da PAIR:

i) Em relação à percepção ambiental: dificuldades para ouvir sons de alarme, sons domésticos, dificuldade para compreender a fala em grandes salas (igrejas, festas), necessidade de alto volume de televisão e rádio.

ii) Problemas de comunicação: em grupos, lugares ruidosos, carro, ônibus, telefone.

Esses fatores podem provocar os seguintes efeitos:

i) Esforços e fadiga: atenção e concentração excessiva durante a realização de tarefas que impliquem na discriminação auditiva.

ii) Ansiedade: irritação e aborrecimentos causados pelo zumbido, intolerância a lugares ruidosos e a interações sociais, aborrecimento pela consciência da deterioração da audição.

iii) Dificuldades nas relaçס̃es familiares: confusōes pelas dificuldades de comunicação, irritabilidade pela incompreensão familiar. 
iv) Isolamento.

v) Auto-imagem negativa: vê-se como surdo, velho ou incapaz.

Esses efeitos produzem também conseqüências na família do trabalhador, que precisa compreender suas dificuldades, e ajudá-lo sem ofendê-lo. A esposa freqüentemente tem que agir como intérprete entre o marido e os filhos, e tentar amenizar as situações de conflito. Na proposta de trabalho de reabilitação deste autor, as esposas são incluidas nos grupos de discussão.

Outro ponto importante é a negação dos trabalhadores sobre seus problemas auditivos. Essa talvez seja a maior dificuldade do processo de reabilitação. 


\section{AÇõES DE ATENÇÃO À SAÚDE AUDITIVA DO TRABALHADOR EXPOSTO AO RUÍDO}

O desenvolvimento de ações em saúde é decorrente de determinadas concepções sobre ela e sobre o processo de adoecimento, permeados pelas condições políticas, econômicas e sociais vigentes.

Essas concepçōes têm sido revistas historicamente e passamos de visões unicausais (biológica) para multicausais, que já consideram os fatores ambientais, mas ainda centradas nos fatores biológicos, até a concepção de determinação social da doença. Esta última, considera a doença como conseqüência da estrutura social, sobre a qual devem ser orientadas as mudanças (PEREIRA 1995).

Apesar da evolução conceitual, as práticas continuam, na sua maioria, centradas num modelo multicausal, com ênfase nas ações de proteção e recuperação.

A saúde auditiva do trabalhador exposto a riscos auditivos acompanha este modelo. As ações são organizadas dentro de um programa específico, já voltado à perda auditiva, caracterizando-se como ações de proteção à saúde. Esse programa é denominado Programa de Conservação Auditiva ou Programa de Prevenção de Perdas Auditivas (PPPA).

FIORINI e NASCIMENTO (2001) discutem a denominação do Programa de Conservação Auditiva (PCA), que não deixa clara a preocupação com as ações de prevenção, mas sim, denota uma aceitação do estado auditivo do sujeito, daí a sugestão da utilização de PPPA.

Independentemente da denominação utilizada, o PPPA é um conjunto organizado de ações com o objetivo de minimizar os riscos, evitando o desencadeamento e/ou agravamento de perdas auditivas relacionadas ao trabalho.

Além de estar previsto na legislação, na NR-9 (Portaria n. 25, de 30.12.1994) e na Portaria n. 19, de 9.4.1998, esse programa têm sido desenvolvido pelas empresas, com o objetivo de controlar a incidência de perdas auditivas, que trazem prejuízos diretos e indiretos ao empresário. 
O programa consta das seguintes etapas: avaliação, gerenciamento e controle dos riscos, gerenciamento audiométrico, seleção e homologação de protetores auditivos, treinamento e programas educacionais e auditoria do programa. É importante ressaltar que o sucesso do programa está diretamente relacionado à efetiva participação de todos os envolvidos na questão, quais sejam, a empresa, os técnicos e o trabalhador (FIORINI e NASCIMENTO 2001).

Dessa forma, verificamos que as ações desenvolvidas num PPPA são caracteristicamente de proteção à saúde auditiva.

As ações de promoção de saúde implicariam em tornar esse ambiente livre de riscos, salubre, adequado para o desenvolvimento do trabalho sem a possibilidade do adoecimento. Ao mesmo tempo, promover educação em saúde, de forma que o trabalhador conhecesse e valorizasse o auto-cuidado. Somente algumas dessas ações, basicamente de orientação, são realizadas no PPPA.

Em relação à reabilitação, ela não aparece integrando o programa, pois, sendo tradicionalmente entendida como uma atividade clínica, não parece se enquadrar no perfil das açōes possíveis de serem realizadas dentro da empresa.

Por outro lado, as ações do serviço público de saúde, também caracteristicamente voltadas à proteção, realizando vigilância sanitária e epidemiológica, além de assistência (avaliação diagnóstica), também não assume o desenvolvimento de ações de reabilitação. Estas ficariam ao cargo do INSS, por meio dos Centros de Reabilitação Profissional.

O trabalhador portador de PAIR não é afastado do trabalho, pois um afastamento temporário não interferirá no agravamento do seu quadro. Além disso, a PAIR não é considerada como lesão incapacitante, o que de imediato, impede 0 acesso do trabalhador a esses Centros.

Descrevemos, a seguir, a avaliação de PAIR, que está incluída no gerenciamento audiométrico do PPPA e relaciona-se às açōes de diagnóstico e tratamento precoce e limitação do dano. 


\subsection{Avaliação da PAIR}

RIGOTTO (1994) considera três elementos fundamentais na investigação da relação entre saúde e trabalho. O primeiro elemento referese à detecção e avaliação do perfil de saúde e dos riscos a que está exposto o trabalhador; o segundo elemento é a detecção e avaliação das alteraçð̃es de saúde precoces ou manifestas, que estão ocorrendo no corpo do trabalhador e o terceiro, é o estudo e a pesquisa sobre as relaçס̃es entre o perfil de saúde e o de risco e as alterações de saúde verificadas. A autora propōe instrumentos específicos para esse trabalho, compostos basicamente por check-lists que facilitam o levantamento dos dados para análise e planejamento das ações de saúde pertinentes.

Esse modelo é o adotado, também, para a avaliação de PAIR. Sendo uma doença relacionada ao trabalho, a primeira informação a ser coletada deve referir-se ao ambiente de trabalho. Portanto, um levantamento o mais detalhado possível sobre o ambiente e o posto de trabalho do indivíduo com suspeita de PAIR, é fundamental. Isso pode ser feito preferencialmente por meio de visita ao local de trabalho, para investigação dos vários riscos existentes, assim como pelo acesso a informações da empresa sobre avaliações de ruído ambiental atualizada, para que, comparando-se os dados de nível de exposição com os dados apresentados nos exames audiométricos, seja possível relacionar-se risco e doença.

MORATA e LEMASTERS (2001) observam a importância de estudos sobre a PAIR, utilizando o método epidemiológico, o que traz confiabilidade aos resultados obtidos e permite a reprodução desses mesmos estudos.

\subsubsection{A avaliação dos efeitos auditivos da PAIR}

Uma vez realizado um levantamento que permita a compreensão do risco, procede-se à avaliação biológica individual, que se inicia com uma anamnese específica sobre a situação auditiva do trabalhador, levando-se em conta a história clínica e ocupacional, tentando compreender suas 
dificuldades e relacioná-las com o quadro audiológico que será analisado posteriormente. No Anexo 1 apresentamos a anamnese audiológica utilizada no Centro de Referência em Saúde do Trabalhador da Secretaria de Estado da Saúde de São Paulo (CEREST/SP).

A anamnese é seguida por uma Inspeção Visual do Meato Acústico Externo (IVMAE), com o objetivo de verificar se há algum impedimento para a realização do exame audiológico (ex. rolha de cerume). Não havendo impedimento, procede-se à avaliação audiológica, que deve ser feita sob determinadas condiçőes, estabelecidas pela Portaria n. 19, da Norma Regulamentadora n. 7 (NR-7):

i) Utilização de cabina acústica.

ii) Utilização de equipamento calibrado.

iii) Repouso acústico de 14 horas.

iv) Profissional qualificado para a realização do exame (médico ou fonoaudiólogo).

Essas condições são fundamentais para que o exame seja confiável, principalmente considerando-se que a audiometria tonal é um exame subjetivo. A necessidade do repouso auditivo dá-se em função da existência da Mudança Temporária de Limiar (MTL), que ocorre após exposição ao ruído e que pode ser confundida com uma PAIR.

Além desses fatores, definidos como extrinsecos ao exame, existem os fatores intrínsecos, que se referem ao paciente e suas condições gerais, motivação, inteligência, atenção, familiaridade com a tarefa, interpretação da instrução do exame.

A avaliação audiológica é formada por uma bateria de exames:

1 - Audiometria Tonal por Via Aérea, na qual busca-se determinar os limiares auditivos do sujeito, ou seja, a intensidade mínima audível para tons puros. O limiar auditivo é definido como o nível mínimo de intensidade sonora necessária para que o tom puro possa ser percebido $50 \%$ das vezes em que for apresentado, para cada freqüência testada. Qualquer pessoa pode ser submetida ao exame audiométrico, desde que seja capaz de responder, de forma sistemática aos estímulos apresentados. Solicita-se ao 
paciente que responda, de alguma forma determinada (levantando a mão, falando "escutei", apertando um botão ou acenando com a cabeça), todas as vezes que ouvir o estímulo (apito) no fone de ouvido, mesmo que seja bem fraco. O procedimento é padrão, podendo haver pequenas diferenças, de acordo com o autor. Para esse estudo, adotamos o procedimento colocado por FRAZZA e col. (2000). Esses autores sugerem que o exame deve iniciarse pela melhor orelha e na seguinte seqüência de freqüências: $1 k, 2 k, 3 k$, 4 k, 6 k, 8 k, 500 e $250 \mathrm{~Hz}$. Todas as vezes que o paciente apresentar dificuldade para responder ao tom contínuo, ou apresentar queixa de zumbido, é importante utilizar o tom modulado (warble) ou pulsátil.

O tom puro é apresentado, inicialmente a 40 dBNA ou em intensidade que o examinador julgar audivel pelo paciente, a partir do comportamento observado e das respostas obtidas na anamnese. Uma vez obtida a resposta, diminui-se a intensidade, gradativamente, em degraus de 10 $\mathrm{dB}(\mathrm{NS})$ até que esta deixe de existir, então se eleva novamente a intensidade em degraus de $5 \mathrm{~dB}$ (NS) até encontrar o limiar naquela freqüência. O som apresentado deve ter a duração aproximada de dois segundos. Deve-se ter cuidado para não ritmar a apresentação dos sinais, pois o paciente pode antecipar a resposta. Os autores sugerem que em casos nos quais o paciente procura observar o examinador para poder responder, é válido a colocação deste paciente de perfil dentro da cabina.

Entretanto, acreditamos que esse procedimento impede o examinador de observar respostas sutis do paciente, como "erguer as sobrancelhas", o que pode interferir na eficácia da avaliação. Os limiares obtidos são anotados no audiograma, cujo modelo e legendas adotadas internacionalmente estão no Anexo 2.

A partir da obtenção dos limiares auditivos por via aérea, é possível determinar se eles estão dentro da normalidade ou se há perda auditiva. A perda auditiva é classificada de acordo com a sua localização anatômica e de acordo com o grau. Quando a lesão está localizada na orelha externa e/ou orelha média, é denominada condutiva, quando a lesão atinge a cóclea e/ou nervo auditivo, é denominada neurossensorial (exemplo: PAIR). Caso a 
lesão apresente componentes condutivos e neurossensoriais, é chamada de mista. Em relação ao grau de perda, a classificação mais correntemente utilizada na clínica é a de DAVIS e SILVERMAN (1960), que se baseia na média dos limiares tonais de $500,1 \mathrm{k}$ e $2 \mathrm{kHz}$. Entretanto, essa classificação acaba por excluir casos típicos de PAIR que ainda não afetaram essas freqüências. Dessa forma, é necessário considerar as freqüências altas ( $3 k$, $4 \mathrm{k}$ e $6 \mathrm{kHz}$ ) na classificação. Isso também permitirá a avaliação de audiometrias seqüenciais, como previsto na Portaria 19.

A PAIR é, de fato, peculiar em relação a classificações. Existem pelo menos quatro tipos de classificações propostas especificamente para essa patologia, em decorrência da limitação da classificação clínica; Merluzzi, Costa, Pereira e Ferreira Jr., são citados por FERREIRA JR. (1998) como exemplos.

2 - Audiometria Tonal por Via Óssea, exame realizado sempre que os limiares por via aérea forem maiores ou iguais a $25 \mathrm{~dB}(\mathrm{NA})$. O exame é semelhante ao anterior, com a diferença de que aqui o sinal é transmitido, por meio de um vibrador ósseo, que deverá ser colocado na mastóide ou na fronte do paciente. A comparação entre os limiares obtidos pelas duas vias torna possível localizar a região da lesão, permitindo definir o tipo de perda auditiva, qual seja, neurossensorial, condutiva ou mista. Nessa avaliação, é necessário o uso de técnicas de mascaramento, pois como a atenuação do som por via óssea é zero, ou seja, as duas cócleas estão sendo estimuladas ao mesmo tempo, torna-se fundamental impedir que a orelha não testada responda pela orelha testada.

3 - Logoaudiometria, exame que avalia as habilidades de sensibilidade e de acuidade dos sons da fala. As medidas de sensibilidade são as pesquisas dos limiares (limiar de reconhecimento de fala e limiar de detecção da voz). As medidas de acuidade são supraliminares, denominadas, índice de reconhecimento de fala (WILSON e STROUSE 2001). A logoaudiometria é utilizada para a determinação da chamada "audição social do indivíduo", considerando que são analisadas as freqüências da fala. Entretanto, sabe-se que a fala é composta por outras 
freqüências não analisadas e que a situação de dificuldade de discriminação apresentada pelo trabalhador portador de PAIR é diferenciada, uma vez que pela anamnese observa-se que as situações de dificuldade comunicativas ocorrem especialmente em ambientes ruidosos. Dessa forma, hoje já são propostos novos meios de realização desse exame, para que ele possa de fato detectar alterações de comunicação no indivíduo portador de PAIR (COSTA 1992). Este autor sugere a utilização de logoaudiometria sensibilizada, ou com ruido de fundo, para que as respostas se aproximem da realidade do paciente.

4 - Imitanciometria, avaliação composta pela timpanometria, que é a medida de pressão da orelha média, determinada pela mobilidade da membrana timpânica em função de uma variação de pressão (positiva e negativa) no meato acústico externo. Enquanto ocorre a variação de pressão, é emitido um som de $220 \mathrm{~Hz}$, cuja reflexão indicará o volume assumido pela orelha média durante essa variação. Além da timpanometria, realiza-se, de rotina, a pesquisa do reflexo acústico. Este reflexo ocorre bilateralmente na presença de um estímulo com suficiente intensidade, mesmo monoaural. Em indivíduos normais, eles aparecem em valores entre 70 a 90 dBNS (nivel de sensação), ou seja, acima dos limiares audiométricos. A pesquisa do reflexo acústico é importante, pois auxilia no topodiagnóstico das lesões.

Essa é a bateria de exames mais comumente utilizada na rotina clínica, já na ocupacional, pode haver pequenas diferenças em relação aos exames propostos. Além desses, os exames de Emissőes Otoacústicas e os Potenciais Auditivos Evocados de Tronco Encefálico (PAETE) também podem ser aplicados.

As emissões otoacústicas são sons de baixa intensidade gerados pela cóclea e transmitidos para a orelha média e canal auditivo. Estão relacionadas a uma determinada freqüência e região específica na membrana basilar. $E$ um teste de aplicação clínica muito recente, que informa sobre o funcionamento do órgão de Corti (órgão espiral) e do sistema eferente auditivo. Suas aplicaçōes clínicas são: procedimentos de 
triagem neonatal, escolar e industrial, avaliação de crianças, monitorização da função coclear e diagnóstico de algumas patologias. É rápido, objetivo e não invasivo (MUNHOZ e col. 2000a). Esse exame tem sido estudado mais aprofundadamente em relação à sua efetividade para a utilização em Saúde do Trabalhador (FIORINI e FISCHER 2000; BERNARDI 2000).

Os PAETE, ou potenciais auditivos evocados de tronco encefálico é um exame que tem grande sensibilidade, é objetivo, rápido e não invasivo. $\dot{E}$ indicado em pacientes com queixas de tonturas, zumbido unilateral, perda auditiva neurossensorial assimétrica, perda auditiva súbita, reconhecimento de fala com limiares incompativeis com os limiares tonais, entre outros. Em Saúde do Trabalhador, a avaliação dos PAETE é indicada em casos de suspeita de simulação, pois o exame não requer colaboração por parte do paciente (MUNHOZ e col. 2000b).

E a partir da comparação de todos os dados levantados em relação ao risco e ao quadro audiológico obtido, que o médico poderá confirmar ou não a hipótese diagnóstica de PAIR. Muitas vezes, há necessidade de avaliação de um especialista (médico otorrinolaringologista), pois o quadro de PAIR é muito semelhante ao de várias outras alterações neurossensoriais, não sendo incomum a realização do diagnóstico por exclusão de outras causas.

A importância da realização do diagnóstico não se resume à clínica, mas também à área trabalhista, uma vez que, caso o diagnóstico seja conclusivo, o trabalhador poderá solicitar benefício ao INSS. Além disso, essa definição permitiria conhecer melhor a incidência dessa doença no Brasil.

\subsubsection{Avaliação dos efeitos não auditivos da PAIR}

A Organização Mundial da Saúde (OMS), em 1980, trouxe as seguintes definições:

- Impairment ou Deficiência: perda, defeito ou problema funcional ou anato̊mico. 
- Disability ou Incapacidade: restrição ou falta de habilidade, conseqüente da deficiência, em executar qualquer atividade que possa ser desempenhada por um indivíduo normal.

- Handicap ou Desvantagem: é a desvantagem para o indivíduo, conseqüente da deficiência ou incapacidade, que o limita ou o impede de desempenhar atividades consideradas normais para a idade, sexo, fatores culturais e sociais. Seriam os efeitos da perda auditiva na vida do indivíduo, como isolamento social, irritabilidade e baixa autoestima.

Muitos estudos classificam os efeitos extra-auditivos do ruído como handicap, mas, em 2001, a OMS publicou uma nova classificação, que não mais utiliza esse termo.

Essa classificação foi a finalização de um processo de revisão desses termos (impairment, disability e handicap), que significou uma modificação da forma de abordagem da saúde, pois agora, preconiza-se a utilização de uma nova classificação de funcionamento, incapacidade e saúde: International Classification of Functioning, Disability and Health (ICF).

O objetivo dessa classificação é proporcionar bases científicas para a compreensão e o estudo da saúde e dos estados relacionados à saúde. Ela fornece uma descrição de situações relacionadas ao funcionamento humano e suas restrições, envolvendo questões sobre o corpo (funçōes e estruturas corporais - body functions and structures), e atividades e participação (activities and participation), relacionados às ações tanto individuais como coletivas. Esses termos, substituem os usados anteriormente, quais sejam impairment, disability e handicap. É, portanto, nesse contexto, que avalia e classifica os danos, deficiências ou incapacidades.

A avaliação dos efeitos não auditivos da exposição ao ruído está relacionada com o significado da perda de audição e suas conseqüências na vida diária do indivíduo. Essa avaliação faz-se necessária para indicar de que forma e quanto essa perda auditiva está interferindo na vida pessoal e profissional do indivíduo. Evidentemente, trata-se de um recorte da 
complexidade do ambiente de trabalho e de suas relações, pois, segundo VENTRY e WEINSTEIN (1982), "uma resposta individual a uma perda auditiva é provavelmente determinada por fatores, tais como, personalidade, ajuste psicossocial, idade e saúde física combinada ao dano auditivo".

Entre os estudos que buscam compreender melhor os efeitos do ruido na vida do indivíduo, está o de WEINSTEIN (1984), que utiliza o termo handicap como sendo os problemas não auditivos resultantes da diminuição da capacidade auditiva e das exigências situacionais de vida diária.

Os estudos de handicap são realizados, em sua maioria com adultos e, principalmente idosos com dificuldades auditivas que buscam um processo de reabilitação cuja base é a adaptação de um aparelho de amplificação sonora individual (NOBLE e ATHERLEY 1970; KAPLAN e col. 1978; GIOLAS e col. 1979; DEMOREST e ERDMAN, 1986). Certamente há diferenças em relação ao trabalhador com PAIR, considerando-se tanto aqueles que ainda estão trabalhando como aqueles que já estão fora do mercado por demissão ou aposentadoria.

A avaliação do handicap decorrente da deficiência auditiva, se utiliza de três tipos de análise: a) medidas de limiar; b) medidas supraliminares; c) questionário de auto-avaliação.

As medidas de limiar foram as descritas anteriormente (audiometria tonal VA e VO, logoaudiometria, imitânciometria). Veremos, a seguir, a avaliação das medidas supraliminares.

LING e LING (1978) e VAN TASSELL (1981) afirmam que vários traços fonéticos podem ser discriminados, apenas quando há a presença da audição para a extensão de freqüências correspondentes às propriedades acústicas desses traços e se a fala for suficientemente intensa, para alcançar o limiar do paciente naquela faixa de freqüência.

Há, também, informações importantes de LEVITT (1982), indicando a diferença de resposta (compreensão) entre indivíduos com a mesma perda auditiva. Isso ocorre em nível supraliminar, e daí a necessidade desse tipo de avaliação. GIOLAS (1999), também indica que os limiares de 
compreensão de fala podem ser obtidos pela logoaudiometria habitual ou adaptada (utilizando-se treinamento prévio, por exemplo).

Para testar a compreensão da fala, em situação mais próxima do cotidiano do indivíduo, é possível utilizar-se os testes supraliminares. Mensagens faladas pré-selecionadas são apresentadas pelos fones de ouvido para cada orelha separadamente ao mesmo tempo, ou então são apresentadas em campo livre. Essas mensagens são apresentadas em condições de silêncio em intensidades consideradas de conversação normal e o teste de campo livre pode incluir testes de reconhecimento de fala com ruído competitivo. Essa avaliação não é utilizada de rotina, pela necessidade de equipamentos específicos.

Avalia-se também, a utilização de pistas visuais pelo indivíduo. Isso, além de fornecer dados de situação auditiva, pode auxiliar nas atividades de reabilitação.

Para avaliar o handicap, os EUA, Canadá e Europa utilizam apenas a avaliação dos limiares, inclusive em processos com solicitação de indenização; acreditamos, entretanto, que essa avaliação não reflete a real situação do indivíduo.

O terceiro tipo de análise, utilizado para uma avaliação qualitativa da dificuldade auditiva, é a aplicação de questionários de auto-avaliação.

A avaliação audiológica, como descrita anteriormente, possibilita a quantificação do tipo e grau de perda auditiva; entretanto, não se pode avaliar a incapacidade auditiva apenas por parâmetros numéricos; é necessário conhecer o paciente e sua demanda auditiva para compreender o significado desta perda em sua vida (ROBINSON e col. 1984). Dessa forma, vários autores propõem a utilização de testes que pretendem quantificar e qualificar a performance auditiva do indivíduo, por meio de instrumentos de auto-avaliação.

ATHERLY e NOBLE (1971) e LUTMAN (1987), utilizando esses instrumentos, conseguiram melhor correlação dos índices com testes de fala (em silêncio e em ruído), testes de localização e de resolução temporal e de freqüência. Os questionários de auto-avaliação foram introduzidos como 
proposta de um novo método para adquirir informações sobre a audição do individuo, como forma de completar os dados audiológicos. Nesses procedimentos são avaliados aspectos emocionas da comunicação, opiniões e comportamentos. Essas informaçð̃es são fundamentais no processo de reabilitaçāo. Na Tabela 2 apresentamos alguns dos principais trabalhos.

Tabela 2 - Instrumentos de auto-avaliação para a verificação do handicap auditivo

\begin{tabular}{|c|c|c|c|}
\hline AUTOR E ANO & INSTRUMENTO & POPULAÇĀO ALVO & $\begin{array}{c}\text { FOCO DE } \\
\text { AVALIAÇÃO }\end{array}$ \\
\hline HIGH e col. (1964) & HHS & $\begin{array}{l}\text { Adultos com perda } \\
\text { auditiva }\end{array}$ & Handicap \\
\hline $\begin{array}{ll}\text { NOBLE } & \text { e } \\
\text { ATHERLEY (1970) }\end{array}$ & HMS & Adultos com PAIR & $\begin{array}{l}\text { Incapacidade } \\
\text { auditiva e handicap }\end{array}$ \\
\hline \begin{tabular}{lll|} 
ALPINER & e & col. \\
$(1974)$ & & \\
\end{tabular} & DSCF & Adultos & $\begin{array}{l}\text { Incapacidade } \\
\text { auditiva e handicap }\end{array}$ \\
\hline $\begin{array}{l}\text { SCHOW } \\
\text { NERBONNE (1977) }\end{array}$ & HHS & $\begin{array}{l}\text { Idosos, } \\
\text { ao candidatos } \\
\text { amplificaçăo sonora }\end{array}$ & Handicap \\
\hline $\begin{array}{llll}\text { KAPLAN } & \text { e } & \text { col. } \\
(1978) & & \\
\end{array}$ & DENVER SCALE & Idosos & $\begin{array}{l}\text { Socialização, } \\
\text { comunicação }\end{array}$ \\
\hline GIOLAS e col. (1979) & $\mathrm{HPI}$ & $\begin{array}{lr}\text { Adultos } & \text { com } \\
\text { dificuldade } & \text { de } \\
\text { comunicação } & \end{array}$ & $\begin{array}{l}\text { Distúrbio, } \\
\text { incapacidade } \\
\text { auditiva e handicap }\end{array}$ \\
\hline HUTTON (1980) & $\mathrm{HPI}$ & Adultos & AASI e comunicação \\
\hline $\begin{array}{l}\text { VENTRY } \\
\text { WEINSTEIN (1982) }\end{array}$ & HHIE & Idosos & $\begin{array}{l}\text { Incapacidade } \\
\text { auditiva e handicap }\end{array}$ \\
\hline $\begin{array}{ll}\text { DEMOREST } & \text { e } \\
\text { ERDMAN (1986) }\end{array}$ & $\mathrm{CPHI}$ & Militares & $\begin{array}{l}\text { Incapacidade } \\
\text { auditiva e handicap }\end{array}$ \\
\hline
\end{tabular}

Nos trabalhos apresentados, verificamos que a preocupação em avaliar o handicap acontece desde a década de 60 , e que foi evoluindo ao longo do tempo, com os vários estudos propostos. Isso reflete uma necessidade proveniente do trabalho de reabilitação. Quando o objetivo não 
se restringe à avaliação, mas sim pretende desenvolver as possibilidades do portador de perda auditiva, temos um contato mais prolongado e um vínculo mais profundo com o paciente, $\mathrm{e}$ isso permite, que possamos compreender $\mathrm{e}$ lidar com as limitações desse paciente. Daí a necessidade de instrumentos que avaliassem essas limitações num primeiro momento, para aumentar a eficácia da reabilitação.

Portanto, na prática clínica, esses instrumentos já foram incorporados, o que não acontece ainda na Saúde do Trabalhador. Isso demonstra como a assistência ao portador de PAIR, é limitada quando comparada à assistência a qualquer outro deficiente auditivo.

Podemos observar, entre os estudos apresentados, aqueles relacionados com a PAIR.

NOBLE e ATHERLY (1970) elaboraram o Hearing Measurement Scale, com o objetivo de avaliar indivíduos com PAIR para atendimento clínico. É um questionário composto por 42 questões divididas em sete sessōes: fala, acuidade para sons não verbais, localização, respostas emocionais, distorção de fala, zumbido e opinião pessoal sobre a capacidade auditiva, podendo ser apresentado em forma de entrevista ou com papel e lápis.

Esse instrumento foi utilizado por AXELSSON (1993), para estudo da percepção de handicap em individuos com PAIR e zumbido, observando a pequena aceitação do problema auditivo e a necessidade de apoio social e de reabilitação.

Ainda baseado neste instrumento, HÈTU (1994), elaborou no Grupo de Acústica de Montreal, um questionário que pudesse ser aplicado na clínica diária, voltado para a avaliação do handicap para PAIR, o Hearing Disability and Handicap Scale (HDHS). O conteúdo do questionário é formado pelas queixas mais freqüentes apresentadas pelos pacientes, como problemas para escutar palavras, sons do ambiente, irritação, isolamento, etc. Os autores adotaram como princípios: a auto-administração do questionário, poucas questóes para que seja respondido rapidamente, fácil acesso ao escore total para avaliação, instrumento de fácil compreensão e 
escala simples de resposta. Esse instrumento foi validado e utilizado em inúmeros estudos, inclusive no Brasil.

SILVA (1997), utilizando a versão traduzida para o português do questionário Hearing Disability and Handicap Scale, especificamente para trabalhadores portadores de PAIR, conseguiu observar as dificuldades mais comuns no dia a dia desses trabalhadores, reforçando os achados dos autores.

VENTRY e WEINSTEIN (1982), elaboraram e padronizaram um instrumento para utilização em reabilitação de adultos idosos (HHIE- Hearing Handicap Inventory for the Elderly). Esse questionário é reconhecido internacionalmente por permitir uma forma simples e rápida de avaliação clínica, podendo ser adaptado a várias línguas pela simplicidade de termos e universalidade das perguntas (Anexo 3 ).

Esses autores desenvolveram e padronizaram o HHIE, com o objetivo de avaliar os efeitos auditivos e não auditivos decorrentes da perda auditiva no idoso. As perguntas pretendem identificar as situações causadoras de dificuldades e o comportamento do indivíduo em relação a elas. Além disso, perguntas de foco emocional procuram conhecer a resposta e atitude emocional do indivíduo frente à deficiência auditiva. $O$ formato de resposta com três alternativas, justifica-se como forma de simplificação e facilidade de aplicação. Foram avaliados 100 indivíduos idosos, 48 do sexo masculino e 52 do sexo feminino, com idade variando entre 65 e 92 anos e, sendo a maioria portadores de perda auditiva neurossensorial. Estes indivíduos foram divididos em cinco categorias de deficiência auditiva, baseadas nas médias dos limiares tonais das freqüências de $500,1 \mathrm{k}$ e $2 \mathrm{kHz}$. Os resultados das respostas ao questionário podem variar de $0 \%$ (sugerindo não percepção de handicap) a 100\% (sugerindo percepção severa do handicap). Observaram uma variação de respostas ao questionário de $0 \%$ a $98 \%$, tendo a média sido de $30 \%$ e o desvio padrão de 27,3 .

WIESELBERG (1997), traduziu, adaptou e aplicou o HHIE numa população de idosos e observou que este instrumento mostrou-se efetivo em 
avaliar o handicap percebido pelo deficiente auditivo idoso em nossa realidade.

NEWMAN e col. (1990), modificaram o HHIE para poder ser utilizado com indivíduos mais jovens ( $<65$ anos), mudando o enfoque de algumas perguntas para observarem os efeitos da deficiência auditiva no ambiente de trabalho, elaborando então o Hearing Handicap Inventory for the Adults (HHIA). Ele foi aplicado em 67 indivíduos adultos, com idades entre 18 e 64 anos, dos sexos masculino e feminino, com audição normal ou portadores de deficiência auditiva, sendo que nenhum havia feito uso de AASI (aparelho de amplificação sonora individual) anteriormente. Os autores concluíram que - HHIA é eficiente para descrever as reações dos adultos mais jovens com relação à sua deficiência auditiva. Reforçaram a sua importância como instrumento de identificação de dificuldades psicossociais resultantes da deficiência auditiva.

MAGNI (1997) analisou as incapacidades auditivas de trabalhadores portadores de PAIR por meio de entrevistas abertas dirigidas aos trabalhadores e às suas respectivas esposas, conseguindo identificar várias situações de limitaçōes como, dificuldade de compreensão de fala e ao assistirem televisão, usar o telefone e em ambientes ruidosos.

\subsubsection{Controle da PAIR}

As ações de controle da PAIR estão relacionadas ao controle do ruído. São as medidas explicadas anteriormente, de controle da exposição na fonte, na trajetória e no indivíduo. Além dessas medidas, ditas de engenharia, podemos dispor de medidas organizacionais, como redução de jornada, estabelecimento de pausas e mudança de função.

A avaliação audiológica periódica permite o acompanhamento da progressão da perda auditiva, que pode variar de acordo com a intensidade e com o tempo de exposição, além da suscetibilidade individual. A velocidade da progressão da perda auditiva determinará a eficácia das medidas de proteção tomadas e a necessidade da aplicação de outras. Os 
efeitos extra-auditivos devem ser considerados nessa avaliação, apesar de não serem previstos pela legislação.

\subsubsection{Reabilitação}

\subsubsection{Definições}

Reabilitação é definida como recuperação das faculdades físicas ou psíquicas dos incapacitados. Reabilitar é restituir ao estado anterior (FERREIRA 1988).

Na saúde, a reabilitação objetiva desenvolver o potencial residual do organismo após haver sido afetado pela doença (PEREIRA 1995).

O objetivo de todo processo de reabilitação é fazer com que o indivíduo portador de alguma limitação possa utilizar ao máximo seu potencial e com isso inserir-se com qualidade na sociedade.

Dessa forma, a reabilitação auditiva procura minimizar qualquer dificuldade que 0 individuo experimente como resultado de uma perda auditiva (STEPHENS 1987). É um processo de resolução de problemas que deve ser planejado de forma a suprir as necessidades particulares do indivíduo deficiente auditivo. Ele se aplica tanto aos indivíduos com perda auditiva congênita como adquirida e envolve desde a avaliação audiológica até a terapia fonoaudiológica.

A deficiência auditiva traz como conseqüências a dificuldade de comunicação, o isolamento, assim como um sentimento de insegurança, na medida em que sinais de alerta (buzina, alarme) elou telefone, campainha, podem não ser percebidos. Atividades simples como fazer compras, pedir informações na rua, ir a um restaurante, conversar com amigos, assistir televisão ou usar o telefone podem ficar comprometidas.

Ela atinge não só a própria pessoa como seus familiares e amigos, além de poder significar risco de desemprego. Portanto, se por um lado, a pessoa portadora de deficiência auditiva nem sempre sabe ou quer informar aos demais quanto ao seu problema, por outro lado, tem-se a desinformação 
ou descaso das outras pessoas que lidam com esses indivíduos (THOMPSON 1993/1994) por isso, a reabilitação deve considerar todas essas questðes.

No processo de reabilitação a primeira etapa é sempre da avaliação da condição atual do sujeito. Essa avaliação busca compreender a perda auditiva do individuo e o individuo com essa perda auditiva, por isso, no caso da PAIR, englobará a avaliação dos efeitos auditivos e não auditivos da exposição ao ruído.

\subsubsection{Estudos sobre reabilitação}

Uma vez levantados os dados sobre as reais queixas e dificuldades de comunicação vivenciadas pelo indivíduo portador de perda auditiva, dá-se inicio à intervenção terapêutica, composta basicamente pelo uso das pistas auditivas, estratégias de comunicaçāo, pistas visuais, manipulação do ambiente e resposta ao fracasso auditivo (GIOLAS 1999).

ROSS (1999) apresenta como componentes de um Programa de Reabilitação uma avaliação audiológica detalhada, administraçăo de uma escala de auto-avaliação, seleção do sistema eletroacústico mais apropriado, orientação e acompanhamento sobre o aparelho auditivo e desenvolvimento de estratégias especificas como leitura orofacial, treinamento auditivo, orientações em grupo, aconselhamento individual e programas específicos para ambientes de trabalho.

GOLDSTEIN e STEPHENS (1981) apresentam uma proposta de trabalho de reabilitação, constituído por:

1 - Avaliação: nessa etapa, observa-se a situação da qualidade de comunicação do indivíduo, por meio da avaliação da integridade dos sistemas auditivo e visual, produção de fala, comunicação não verbal, comunicação em geral e existência de reabilitação prévia. Também săo analisados os fatores associados como, o psicológico, sociológico, vocacional e educacional, assim como as suas condições 
de locomoção, funcionamento dos membros superiores e alteração otológica relacional.

2 - Intervenção: trabalha-se as atitudes de aceitação, compreensão e expectativas (aconselhamento); verifica-se a possibilidade de utilização de amplificação sonora e, em caso afirmativo dá-se procedimento à sua adaptação; desenvolvimento de estratégias de comunicação individualizadas e análise do ambiente de trabalho e doméstico para verificar necessidades e possibilidades de adequação; utilização de recursos auxiliares como assistência médica e social; acompanhamento e aconselhamento periódico.

A partir da avaliação da perda auditiva e de seu significado para o trabalhador (efeitos auditivos e não auditivos), inicia-se a intervenção pelo aconselhamento.

Estratégia citada por GOLDSTEIN e STEPHENS (1981), o aconselhamento é um importante instrumento que pode ser absorvido como prática pelos serviços de atenção à saúde do trabalhador. Ele é definido como fornecimento de informações, explicaçס̃es e apoio para guiar as opçőes, atitudes ou comportamentos dos indivíduos deficientes auditivos (HODGSON 1989). Pode ser feito por intermédio de acompanhamento individual durante o processo de seleção e adaptação de aparelho auditivo e/ou durante as sessőes de terapia fonoaudiológica. Também pode ser realizado em grupo, quando a troca de sentimentos e experiências vivenciadas facilita a adaptação à perda auditiva e suas conseqüências.

Portanto, no serviço de saúde do trabalhador, pode ser realizado em retornos de exames, no acompanhamento da utilização de protetores auditivos ou em grupos previamente agendados.

O trabalho em grupo é bastante interessante porque os pacientes se beneficiam ao perceberem que outras pessoas passam por dificuldades semelhantes, além disso, conseguem trocar experiências e idéias de estratégias facilitadoras da comunicação. 
Esse trabalho é fundamental na PAIR, para que os trabalhadores compreendam a origem e as conseqüências do problema e, a partir dessa compreensão, valorizem as ações dos programas de prevenção.

Segundo MCLAUCHILIN (1992), o trabalho de aconselhamento é influenciado diretamente por vários fatores:

- Severidade da deficiência

- Idade do aparecimento e progressão da perda auditiva

- Idade atual

- Interesse pessoal

- Intenção de usar aparelho de amplificação sonora individual (AASI)

- Atitude do usuário sobre o uso da amplificação

- Atitudes dos membros da família e conhecidos sobre o uso e sobre o usuário de aparelho auditivo

- Experiência prévia e conhecimento sobre aparelhos auditivos

- Complexidade do sistema de amplificação utilizado

- Inteligência e habilidades de linguagem

- Existência de reabilitação prévia

- Presença de outros comprometimentos

Devem ser considerados ainda os aspectos emocionais e sociais de cada indivíduo. As pessoas que não ouvem bem tendem a isolar-se socialmente com receio de ter que enfrentar situações de comunicação constrangedoras, pois terão dificuldades em compreender o que está sendo dito e não querem expor seu problema, principalmente no ambiente de trabalho, pois o trabalhador sabe que não deve expor suas limitações, sob risco de tornar-se alvo de gozaçōes dos colegas, ou pior ainda, sob risco de demissão.

Dessa forma, o processo de aconselhamento do trabalhador, baseado no que foi colocado anteriormente, terá características específicas relacionadas à compreensão das limitações provocadas pela perda auditiva, a utilização de aparelho (se possível), a compreensão das necessidades de mudança no ambiente/processo de trabalho e a necessidade de informaçōes sobre os aspectos legais desse tipo de perda auditiva. 
A proposta de reabilitação desse trabalho segue a linha apresentada por GETTY e HETÙ (1991), a qual compōe-se de um trabalho em grupo, que objetiva mostrar ao trabalhador que sua doença é comum e tem origem no ambiente de trabalho, discutindo as seguintes questões:

- Natureza do problema auditivo: o que eu tenho, por que eu tenho, o que significa, o que posso fazer diante disso?

- O aparelho de amplificação sonora individual: vantagens, desvantagens, manuseio, cuidados.

- Aceitação, motivação: informação, discussão em grupos de trabalhadores acometidos, aproximação e esclarecimento aos familiares, aconselhamento.

- Técnicas comunicativas: pistas adicionais, estratégias de comunicação adaptadas ao ambiente de trabalho.

O programa de reabilitação proposto por estes autores, para o trabalhador portador de PAIR, é baseado num modelo de Saúde Pública (BLUM 1981) que parte da análise das diferentes causas de um problema de saúde, para que seja possivel identificar os vários niveis de intervenção que podem reduzir a influência dos fatores causais.

Na PAIR, podemos adotar esse modelo, a partir da identificação dos problemas vivenciados pelo trabalhador. Então, por exemplo, se um dos problemas identificados é a reduzida habilidade de comunicação, deve-se avaliar as conseqüências desse problema na vida do indivíduo para então definir as estratégias de atuação. Trata-se, resumidamente, de montar um esquema que permita a visualização de todo o processo, qual seja: problemas identificados, conseqüências relacionadas e formas de intervenção. A utilização desse tipo de esquema facilita a compreensão e dimensionamento do problema em uma visão epidemiológica e deve ser utilizado, segundo esses autores, como ponto de partida no trabalho individual.

A intervenção proposta por esses autores, consta de: apoio psicossocial, pelo qual o portador de deficiência possa suportar os efeitos da PAIR; informação para o portador de PAIR, sua família, seu ambiente de 
trabalho, serviços de saúde pública e população em geral, sobre a perda auditiva, suas características e conseqüências e desenvolvimento de habilidades, por meio de estratégias que facilitem a comunicação.

Ainda, neste trabalho, os autores colocam a necessidade da participação das pessoas que se relacionam com o trabalhador no seu processo de reabilitaçăo, em especial suas esposas.

GIOLAS (1999) apresenta uma proposta de grupo de orientação com a finalidade de dar ajuda substancial e suporte para pessoas que têm distúrbios de comunicação associados à deficiência auditiva. A meta é analisar os fracassos auditivos que provocam dificuldades na realização das atividades de vida diária (AVD) e desenvolver comportamentos concretos que resultem na melhora da comunicação. E formado um grupo no qual exista um ambiente que permita a troca de informaçôes, suporte mútuo e valorização das queixas apresentadas pelos pacientes e das soluções propostas. As atividades desenvolvidas baseiam-se no uso ótimo de pistas auditivas e visuais, manipulaçăo do ambiente e resposta ao fracasso auditivo.

\subsubsection{Método do trabalho de reabilitação auditiva do trabalhador exposto ao ruído}

O modelo de atenção integral à saúde, proposto pelo Sistema Único de Saúde, enfatiza as açōes de promoção e proteção, em relação às de recuperação.

Entendendo a promoção de saúde como um processo que pretende capacitar a comunidade a atuar com responsabilidade e criatividade nos fatores determinantes da sua saúde, percebemos que esse processo prescinde de uma proposta pedagógica que favoreça a apropriação dos programas de saúde pela comunidade. Esse é o papel da Educação em Saúde.

De uma prática centrada na transmissão de informações, a Educação em Saúde foi incorporando outros conhecimentos como a Ciência do Comportamento, que considerava essencial conhecer a comunidade para 
então determinar os objetivos a serem alcançados, até o desenvolvimento de uma proposta pedagógica baseada na participação. Diferente das anteriores, essa prática considera, de fato, o sujeito e, portanto, a comunidade, como possuidores de cultura, vontade e conhecimentos que não devem ser valorizados como instrumento para o alcance de determinados objetivos, mas como conhecimento a ser compartilhado com a equipe de saúde (MENDES e VIANNA 2000).

Dessa forma, a educação para a participação em saúde pretende provocar o envolvimento da população nos programas de saúde, promover transformações conceituais na compreensão da saúde e gerar atitudes e procedimentos novos frente aos problemas da doença, de modo que seja encarada como responsabilidade de todos e não somente como atribuição governamental.

Portanto, desenvolver ações de educação em saúde junto ao trabalhador exposto ao ruído, significa considera-los como co-responsáveis por todo o processo do Programa de Conservação Auditiva ou Programa de Prevenção de Perdas Auditivas. A participação dos envolvidos é sempre apontada como fundamental para a melhoria das condiçōes de trabalho.

Essa participação, para ser efetiva, deve garantir que os envolvidos estejam motivados para as questőes discutidas e que além dos deveres, os direitos também sejam compartilhados. Um desses direitos, o qual relacionase ao papel do profissional de saúde, é o direito à informação. Nesse contexto é que devem ser realizados os referidos programas, incluindo as ações de reabilitação, sejam realizadas na empresa ou no SUS.

A elaboração de uma metodologia de reabilitação para portadores de PAIR, que pretenda ser uma ação educativo-terapêutica, deve tentar assegurar que a forma de intervenção propicie ao trabalhador, mais do que informação, uma reflexão sobre sua saúde e seus determinantes, a partir de sua vivência pessoal e profissional. Nesse modelo, o profissional de saúde tem o papel de organizar a discussão, favorecendo a participação de todos no grupo, e valorizando suas contribuiçōes para essa reflexão. O profissional de saúde é mais um a contribuir, com informaçōes especificas, que possam ser utilizadas, ou năo, para uma melhor contribuição da realidade. 


\section{O MOTORISTA DE ÔNIBUS URBANO}

\subsection{Histórico do transporte coletivo em São Paulo}

O transporte coletivo em São Paulo surge vinculado ao crescimento urbano da cidade em conseqũência da expansão da cultura agrícola cafeeira. Em 1872, a Companhia Carris de Ferro de São Paulo inaugura a primeira linha de bondes puxados a burro (LOPES 1985).

Em 1920 inicia-se a utilização do ônibus com motor a combustão (jardineiras), sistema de menor custo que o de bonde, o que colabora na viabilização do processo de urbanização para as camadas de baixa renda, ou processo de periferização. Nos anos 30, a capital de São Paulo já era considerada um grande centro urbano e convivia com um trânsito agitado. $A$ opção do governo por privilegiar o transporte individual fica clara nesse momento com a aprovação do Plano de Avenidas de Prestes Maia, que é aprovado em detrimento do estudo de transportes coletivos da Companhia Light.

Com a Segunda Guerra Mundial (1939-1945) faltam peças de reposição, as tarifas não cobrem os custos operacionais e frotas ficam depreciadas. O final desse período é marcado pelo crescimento industrial de São Paulo, resultante da política de industrialização adotada por Getúlio Vargas e continuada por Juscelino Kubitscheck, caracterizado pelo desenvolvimento da indústria automobilística (BARBOSA 2001). É com esse pano de fundo que, em 1947 é criada a Companhia Municipal de Transporte Coletivo (CMTC), que tinha exclusividade na operação de transporte coletivo em São Paulo, resguardando-se o direito da prefeitura de contratar serviços de terceiros quando a CMTC não tivesse condições de operar o sistema. Ente 1950 e 1969 foram contratadas 32 empresas privadas.

No periodo de 1960 a 1970 , o número de automóveis passou de 165.000 para 640.000 e até 1980 já havia atingido 1,8 milhão. Atualmente, estima-se que o município de São Paulo possua uma frota de 4,6 milhões de veículos circulantes (BARBOSA 2001). 
Apesar do aumento da demanda, o transporte coletivo continua sendo relegado a um segundo plano pelo governo, o que se observa pela construção e ampliação de redes arteriais e vias expressas e adoção de técnicas modernas de operação de trânsito como o controle de semáforos por computador. Em 1976, foi criada a Companhia de Engenharia de Tráfego de São Paulo (CET-SP), que implantou vários planos de circulação e criou o sistema de estacionamento conhecido como área de "zona azul".

Com a crise do petróleo a partir de 1973, o sistema ferroviário é incentivado e há investimentos no sistema de trólebus e de metrô. Mesmo assim os investimentos são insuficientes diante da crescente demanda.

Nos anos 80 são implantadas inovações pela CMTC como o Programa Trólebus, os corredores de ônibus (faixa exclusiva) e utilização de gás metano como combustivel em alguns ônibus. Em 1991 o sistema de remuneração de serviço das empresas contratadas, que era pela apropriação direta da tarifa paga pelo passageiro, passa a ser de acordo com os custos aferidos pela Prefeitura.

Em 1993, a CMTC atuava como gestora e operada. Esse fator, associado à alteração do perfil da frota e os altos investimentos necessários pela grande quantidade de ônibus e de funcionários, originaram a transformação da CMTC em São Paulo Transportes, em 1995, que ficou voltada somente à gestão do sistema de transporte da cidade.

Hoje, a São Paulo Transportes ainda gerencia o transporte do município de São Paulo. Algumas alterações têm sido feitas (catraca eletrônica) e outras estão sendo planejadas (carteirinha magnética). Fora do município de São Paulo, as empresas de transporte público convivem com as de transporte privado com maiores ou menores conflitos. Cada região tem sua forma de funcionamento específica.

\subsection{Perfil dos motoristas de ônibus urbano de São Paulo}

SOUZA e col. (1991) em estudo sobre as condições de saúde dos motoristas de ônibus, observaram por meio de questionário aplicado a 925 
motoristas e cobradores que a maior parte dos motoristas são da região sudeste $(53 \%)$, seguido pela região nordeste (39\%), sendo que $56 \%$ nasceram no interior dos Estados e somente $16 \%$ deles estão em São Paulo há pelo menos 15 anos.

A média de idade dos motoristas é de 40,8 anos, sua escolaridade é baixa; $19 \%$ dos motoristas são analfabetos, $50 \%$ possuem primário completo, $25 \%$ ginásio incompleto ou completo e $4 \%$ possuem colegial incompleto e mais.

O salário dos motoristas fica, em sua maioria, entre cinco e 6 salários mínimos. A grande maioria (96\%) reside em casa ou apartamento e $2 \%$ moram em barraco. $O$ tempo gasto para o deslocamento da residência ao trabalho e vice-versa é de mais de uma hora para $35 \%$ dos motoristas; além disso, $41 \%$ deles iniciam sua jornada entre quatro e 6 horas da manhã. Para $35 \%$ dos motoristas, as horas de sono não são suficientes para descansar.

Em relação à experiência profissional, $72,8 \%$ dos motoristas já tinham experiência anterior. A sindicalização abrange $80 \%$ dos motoristas.

Ainda em relação ao trabalho de SOUZA e col. (1991) os seguintes fatores de risco são referidos pelos motoristas:

- $\quad 83 \%$ dos motoristas referem que o motor dianteiro causa calor. $73 \%$ refere que causa barulho.

- $\quad 26 \%$ dos motoristas refere que o motor dianteiro solta fumaça na cabine.

- Como não há local adequado, $66 \%$ dos motoristas utilizam banheiro de bar ou padaria. $58 \%$ dos motoristas têm 30 a 40 minutos para refeição, sem local adequado ( $26 \%$ se alimentam dentro do próprio ônibus).

- $\quad 78 \%$ dos motoristas trabalha além da jornada estipulada (6 horas e 40 minutos), ou porque a empresa exige ou para aumentar o salário.

- $\quad$ Alguns trabalhadores chegam a cumprir 12 horas de jornada diária. $10 \%$ considera o volante duro, $28 \%$ considera a embreagem 
dura e a manutenção é considerada ruim por até $41 \% .14 \%$ dos motoristas não trabalham com bancos reguláveis.

- Em relação aos fatores de estresse: $37 \%$ fica irritado com o som da campainha, principalmente quando são dados vários toques seguidos. $42 \%$ dos motoristas referem que pagam o conserto em caso de acidente com o ônibus e $89 \%$ pagam as multas. $O$ trânsito é considerado intenso para $37 \%$ dos motoristas. Situações de trabalho apontadas como estressantes pelos próprios motoristas e cobradores em ordem decrescente de importância: pessoas que sobem pela porta dianteira, passageiros que descem pela porta traseira, trânsito congestionado, responsabilidade sobre a vida dos passageiros, passageiros que fazem algazarra, ter que trabalhar com barulho, enfrentar calor intenso durante as viagens, passageiros que conversam com o motorista e o cobrador, fazer hora-extra. Quando são levantadas ocorrências agradáveis, o próprio trabalho é apontado por $43,1 \%$ dos motoristas, seguido pelas interações pessoais, com $41,9 \%$ das referências. Na distribuição dos motoristas segundo atividades realizadas no dia de folga, observa-se $23,3 \%$ dorme/descansa, $22,5 \%$ passeio com a familia/viagens, $21,6 \%$ realiza serviços domésticos/reparos em casa e 10,1\% assiste televisão, vídeo, ouve rádio.

\subsection{Morbidade}

A morbidade referida e a observada entre os motoristas de ônibus, tem sido objeto de estudo de vários pesquisadores. Alguns deles são apresentados aqui, sendo categorizados de acordo com o tema do trabalho.

\subsubsection{Estudos sobre morbidade em geral}

Num estudo sobre estresse, KOMPIER e col. (1990) observaram que o absenteísmo foi três vezes maior em motoristas do que a média nacional; o risco de incapacidade foi duas vezes maior do que no grupo controle; 
motoristas que deixam o trabalho por motivo de saúde fazem isso mais jovens do que outras categorias. As principais queixas são músculoesqueléticas, desordens mentais e distúrbios cardio-vasculares. $O$ estudo mostra que o absenteísmo por longos períodos é um fator precursor para futura incapacidade. A surdez á apontada nesse trabalho como uma das doenças que levam à incapacidade, em comparação a outras funções. No Brasil, SOUZA e col. (1991), aponta como as queixas mais freqüentes referidas pelos motoristas: aparelho músculo-esquelético $(50 \%)$; digestivo (22\%), circulatório (20\%); respiratório (18\%) e nervoso (9\%). As queixas em relação ao ouvido são referidas por $2,7 \%$ dos motoristas. Quando a pergunta é direcionada à audiçăo, $21 \%$ dos motoristas refere queixas de dificuldade para ouvir e zumbido. Distúrbios psiquiátricos menores são referidos por $12,7 \%$ dos motoristas, a partir de instrumento especifico. $O$ consumo de bebida alcoólica é grande (54\%), sendo que isso acontece para $54,8 \%$ dos motoristas nas folgas, para $27,4 \%$ depois do trabalho e $15,6 \%$ antes do trabalho.

Nove grupos de cinco motoristas foram entrevistados por AHUMADA e col. (1991), sobre as condições de trabalho e possiveis riscos à saúde. A partir desses resultados, foi elaborado um questionário de morbidade em 170 motoristas e dois grupos controle. Observou-se nos motoristas prevalência elevada de transtornos respiratórios, neuropsiquiátricos, hipertensão arterial, e surdez, entre outros.

Num trabalho realizado pelo Centro de Referência de Saúde do Trabalhador de Santo Amaro (POZZI 1993), levantando riscos à saúde através de questionário com 67 trabalhadores, mostrou que os riscos indicados pelos trabalhadores são, em ordem decrescente de importância: fatores estressantes (atenção aos perigos iminentes); agentes físicos (ruído) e condições sanitárias de higiene e conforto. Os motoristas referem como agentes causadores de acidentes de trabalho e lou doenças ocupacionais: trabalhar com veículos pesados, motor dianteiro, falta de manutenção dos freios, ruído em excesso, poluição do ar, trânsito, aglomeração de pessoas/ usuários doentes/ assalto. As doenças referidas são em maior número 
problemas na coluna, seguidos por problemas auditivos, nervosismo, dor de cabeça, gastrite. Ainda em relação ao ruído, são apontadas três fontes geradoras: motor, campainha e trepidação da carroceria.

EVANS (1994) refere que os motoristas apresentam alteraçōes cardiovasculares e distúrbios gastrointestinais em excesso em relação a outras categorias profissionais. Essas doenças têm papel etiológico significativo no estresse. Da mesma forma aponta a aposentadoria precoce e os distúrbios psiquiátricos. Relata os fatores de estresse considerados mais significativos como pressão de tempo, tumulto de passageiros, congestionamentos, dificuldades ergonômicas e mecânicas, turnos de trabalho que interferem na vida social e familiar, ausência de controle sobre o trabalho, falta de manutenção dos ônibus.

KOMPIER e col. (1996) refere que o absenteísmo e problemas de saúde são mais prevalentes em motoristas do que em outras categorias profissionais. Coloca como os principais problemas de saúde os músculoesqueléticos, psicológicos, gastrointestinais e distúrbios de sono. Os autores citam o ruido como um fator de risco físico que também origina estresse.

SANTOS JUNIOR e col. (1996) em estudo sobre a morbidade de motoristas de ônibus de Belo Horizonte, constatou a falta de padronização nos exames pré-admissionais e apontou as doenças do aparelho músculoesquelético como as mais prevalentes nos motoristas. Observou também que os motoristas apresentam níveis pressóricos elevados durante a jornada de trabalho. No seu trabalho, apresenta um levantamento de queixas, sintomas e doenças apresentadas pelos motoristas, do qual consta a diminuição da audição.

\subsubsection{Estudos sobre alterações cárdio-circulatórias}

Em estudo com 1500 motoristas, RAGLAND e col. (1987), observaram uma prevalência maior de hipertensão nessa categoria, quando comparada a outras. PINHO e col. (1991) encontraram hipertensão arterial em 32\% da amostra de motoristas, os quais tinham registros normais nos exames 
admissionais. ROSENGREN e col. (1991) demonstram uma incidência de distúrbios cardio-circulatórios de 18,4\% em motoristas, comparada a 6,4\% no grupo controle. CARRERE e col. (1991) observaram elevações de catecolaminas e de pressão arterial durante a jornada de trabalho dos motoristas de ônibus.

Procurando estudar mecanismos de riscos cardiacos entre profissionais, BELKIC e col. (1994) revelam que estímulos como faróis de carro elicitam hiperatividade cardiovascular e sinais eletroencefalográficos de despertar. Esses autores também apontam o ruído como um dos agentes físicos nocivos que devem ser investigados para intervenção. Ainda em relação a esse fator de risco, GUSTAVSSON e col. (1996), observaram aumentada incidência de infarto do miocárdio entre motoristas de ônibus. Consideram que as condições psicossociais do trabalho podem responder em parte por isso.

\subsubsection{Estudo sobre alterações respiratórias}

ZUSKIN e col. (1994) observaram que o longo tempo de trabalho como motoristas de ônibus e como mecânicos, particularmente em combinação com o hábito de fumar, pode estar associado com o desenvolvimento de sintomas crônico- respiratórios e deficiência da função pulmonar.

\subsubsection{Estudos sobre câncer}

NETTERSTROM e col. (1988), estudaram a incidência de câncer em 2.465 motoristas de ônibus durante um período de seis anos e observaram aumento de risco para câncer de bexiga e de pele.

SOLL-JOHANNING e col. (1998) analisaram 18.174 sujeitos de 1900 a 1994, por meio de dados de arquivos de empresas e do serviço de registro de câncer. $O$ estudo demonstrou que motoristas de ônibus e empregados do 
sistema de bonde tem risco aumentado de desenvolver diversos tipos de câncer (pulmão, laringe, rim, pele, fígado). Sugerem os autores que a explicação deve relacionar-se à exposição a agentes tóxicos durante o trabalho.

\subsubsection{Estudos sobre estresse}

DUFFY e col. (1990), procurando por fatores de estresse, estudaram a relação entre saúde mental e a satisfação no trabalho dos motoristas. Eles apresentam índices desfavoráveis de saúde mental e menor índice de satisfação no trabalho do que o grupo controle.

KÜHLMANN (1990) procurou identificar as formas pelas quais os motoristas lidam com os eventos estressantes do seu dia-a-dia e observou que eles se utilizam mais do processo de enfocar a emoção (administrar seus distúrbios emocionais) do que o de enfocar o problema (procurar modificar a relação estressante), o que seria mais eficaz.

EVANS e col. (1991) mostram um alto grau de associação entre exposição a condições de pico de tráfego e elevação de catecolaminas urinárias durante o trabalho. Mostram também que reduções no controle percebido no trabalho explica parcialmente as relaçōes entre tráfego congestionado e estresse psicofisiológico.

BROWN e col. (1994), em estudo sobre a fadiga, observou que a fadiga é insuficientemente reconhecida e registrada como causa de acidentes na estrada e que seus efeitos fundamentam-se mais sobre as horas de trabalho irregulares e prolongadas do que sobre o tempo dispendido no volante.

SATO (1995), procurando caracterizar o conceito de trabalho penoso, utilizou a teoria das representaçōes sociais e observou que a falta de controle sobre o trabalho é um dos fatores de penosidade.

Em estudo sobre risco de Distúrbios Psiquiátricos Menores (DPM) (SOUZA e SILVA 1998), o trânsito intenso, o banco sem regulagem, as 
alterações de escala de trabalho, dormir menos de 6 horas diárias e o absenteismo, aparecem como fatores de risco importantes.

\subsubsection{Estudos sobre ruído e perda de audiçāo}

CAMPANA (1973), em tese de doutorado pioneira nesta área, analisou os riscos mais significativos, ruído e vibração, verificando a exposição superior aos limites permitidos e categorizando a função de motorista de ônibus como de risco para o desenvolvimento de PAIR.

BRITTO (1975), também aponta o ruído como um fator de risco importante para os motoristas de ônibus, em estudo na cidade do Rio de Janeiro.

PICALUGA (1983), descreve as condições de trabalho dos motoristas de ônibus do Rio de Janeiro, discutindo sua ação sindical. A autora cita pesquisa realizada em 1981, por alunos da disciplina Medicina Preventiva II da Universidade Federal do Rio de Janeiro, na qual aparece a surdez com uma incidência de $24 \%$.

FONSECA e col. (1993), em medição realizada a pedido do sindicato dos condutores, constataram que, nos ônibus com motor dianteiro, a dose de ruído aproxima-se muito, ou supera a unidade.

CORDEIRO e col. (1994) realizaram estudo seccional com motoristas e cobradores de ônibus da cidade de Campinas, encontrando uma prevalência de PAIR de $45,2 \%$ e, por meio de análise de regressão linear, associação positiva entre PAIR e tempo total de exposição ao ruido, como também com a idade.

SESHAGIRI (1998) realizou 400 medições de ruido em caminhōes e observou que os motoristas tem uma exposição que certamente excede o limite de tolerância com rádio ligado e janela aberta.

MARQUES (1998) analisou uma população de 92 motoristas, observando uma prevalência de $55,4 \%$ de traçados audiométricos sugestivos de PAIR. 
Pesquisa realizada pela Fundação SEADE e FUNDACENTRO (2000) apresentou um índice de $18,8 \%$ de referência de problemas auditivos.

Apresentamos abaixo, um quadro demonstrativo dos estudos realizados com motoristas de ônibus, indicando o ruído como um fator de risco importante ou indicando queixa/ existência de perda auditiva:

Tabela 3 - Estudos e riscos auditivos.

\begin{tabular}{c|c}
\hline AUTORJANO & RISCO IDENTIFICADO \\
\hline CAMPANA (1973) & RUIDO \\
\hline BRITTO (1975) & RUÍDO \\
\hline PICALUGA (1983) & SURDEZ \\
\hline KOMPIER (1990) & SURDEZ \\
\hline AHUMADA (1991) & SURDEZ \\
\hline POZZI (1993) & SURDEZ \\
\hline FONSECA (1993) & RUÍDO \\
\hline CORDEIRO (1994) & PAIR \\
\hline KOMPIER (1996) & SURDEZ \\
\hline SANTOS JUNIOR (1996) & SURDEZ \\
\hline MARQUES (1998) & PAIR \\
\hline SEADE-FUNDACENTRO (2000) & PERDA DE AUDIÇÅO
\end{tabular}




\section{OBJETIVOS}

\subsection{Objetivo geral}

O objetivo desse estudo é elaborar e aplicar uma proposta de trabalho educativo-terapêutico de reabilitação auditiva em motoristas de ônibus urbano, com dificuldades de comunicação provocadas pela Perda Auditiva Induzida por Ruído (PAIR).

\subsection{Objetivos específicos}

- Avaliar as conseqũências da PAIR na comunicação.

- Verificar se há relação entre grau de perda auditiva e grau de severidade das dificuldades de comunicação.

- Indicar possíveis modificações no ambiente de trabalho e processo produtivo, que garantam ao trabalhador melhores condiçōes de trabalho, apesar de suas dificuldades de comunicação. 


\section{MATERIAL E MÉTODO}

\subsection{População de estudo}

A população escolhida para o estudo é de motoristas de ônibus urbano, por tratar-se de função na qual, além da exposição significativa a ruído, há exigência de utilização da comunicação oral, o que poderia favorecer a percepção de dificuldades nessa área. Além disso, seus horários de trabalho, em turnos, viabilizariam a efetivação da proposta de reabilitação, que consiste na realização de grupos educativo-terapêuticos.

Os trabalhadores avaliados pertencem a duas empresas de ônibus da Grande São Paulo. A empresa A autorizou a realização da pesquisa a partir da apresentação do projeto. Os trabalhadores da empresa $\mathrm{B}$, realizaram os procedimentos, com autorização, como parte do trabalho de fiscalização do CEREST.

Os critérios de inclusão dos sujeitos foram:

- Ser portador de PAIR.

- Apresentar dificuldades de comunicação.

Tabela 4 - Distribuição da população estudada, segundo faixa etária.

\begin{tabular}{c|c|c|c}
\hline Faixa etária (anos) & N & $\%$ & \% acumulado \\
\hline $25-30$ & 8 & 7,5 & 7,5 \\
$31-35$ & 14 & 13,2 & 20,8 \\
$36-40$ & 32 & 30,2 & 50,9 \\
$41-45$ & 24 & 22,6 & 73,6 \\
$46-50$ & 28 & 26,4 & 100 \\
\hline Total & 106 & 100 & \\
\hline
\end{tabular}


Tabela 5 - Distribuição da população estudada, segundo tempo de exposição a ruído.

\begin{tabular}{c|c|c|c}
\hline $\begin{array}{c}\text { Tempo de exposiçăo } \\
\text { (anos) }\end{array}$ & $\mathbf{N}$ & $\%$ & \% acumulado \\
\hline $1-5$ & 16 & 3,8 & 3,8 \\
$6-10$ & 34 & 15,1 & 18,9 \\
$11-15$ & 22 & 32,1 & 50,9 \\
$16-20$ & 22 & 20,8 & 71,7 \\
$21-25$ & 7 & 20,8 & 92,5 \\
$25-30$ & 1 & 6,6 & 99,1 \\
$31-35$ & 106 & 0,9 & 100 \\
\hline Total & & 100 & \\
\hline
\end{tabular}

A maioria da população concentra-se na faixa entre 36 e 40 anos, sendo que o percentual acumulado até $50,9 \%$ também está nessa faixa. Em relação ao tempo de exposição, a população concentra-se na faixa entre 11 e 15 anos.

\subsection{Procedimentos utilizados para a avaliação da população}

\subsubsection{Avaliação da PAIR}

Para identificar os sujeitos portadores de PAIR, foi realizada a avaliação audiológica, que compreende a inspeção visual do meato acústico externo (IVMAE), anamnese clínico-ocupacional, audiometria tonal, logoaudiometria e imitânciometria. A escolha desses instrumentos baseouse na rotina clínica de qualquer serviço de audiologia. $O$ total de trabalhadores submetidos a essa avaliação foi de 106.

Essa avaliação foi realizada parte no CEREST e parte em uma das empresas participantes do estudo. Em ambos os casos, os equipamentos (Maico MA 18, Siemens AD 17, AZ 7 e AT 22 ) e a cabine estavam de acordo com os padrōes de calibração estabelecidos, nacional e internacionalmente. A garantia de que o nivel de ruído de fundo não 
interferisse no exame no caso da realização na empresa, deu-se através de calibração biológica.

Os resultados foram classificados de acordo com o critério de MERLUZZI (1981), no qual os graus de severidade seguem a progressão natural da PAIR, ou seja, início entre 3,4 ou $6 \mathrm{kHZ}$, sendo as outras freqüências ainda preservadas; na piora, dá-se o alargamento da curva audiométrica, que passa a atingir as freqüências de 2 k,1 k e $500 \mathrm{~Hz}$, respectivamente. $\mathrm{O}$ graus são:

Grau 0 . traçados audiométricos normais; todas as freqüências analisadas estão com limiares em intensidades até $25 \mathrm{~dB}(\mathrm{NA})$.

Grau 1: as freqüência entre 500 a $3 \mathrm{kHz}$ estão dentro da faixa até 25 $\mathrm{dB}$ e os limiares de $4 \mathrm{e} / \mathrm{ou} 6 \mathrm{kHz}$ estão acima deste limite.

Grau 2: as freqüências entre 500 e $2 \mathrm{kHz}$ estão dentro da faixa até 25 dB e já ocorre perda em $3 \mathrm{kHz}$.

Grau 3: as freqüências de 500 e $1 \mathrm{kHz}$ estão dentro da faixa até $25 \mathrm{~dB}$ e já ocorre perda em 2 kHz.

Grau 4: somente a freqüência de $500 \mathrm{~Hz}$ ainda está na faixa de normalidade.

Grau 5: todas as freqüências analisadas estão apresentado perda.

Grau 6: traçados audiométricos sugestivos de PAIR e outra causa.

Grau 7: traçados audiométricos não sugestivos de PAIR. Esses traçados foram excluídos da amostra.

Portanto, foram incluídos nesse estudo, os trabalhadores com grau de perda de 1 a 6 , bilateral.

O diagnóstico clínico, que determina a patologia, é de responsabilidade de médico, por isso, para nos assegurarmos de incluir no estudo, somente os casos característicos de PAIR, foram seguidos os seguintes critérios, além da configuração da curva audiométrica:

a) Idade máxima de 50 anos, uma vez que a partir dessa idade já é comum a ocorrência de presbiacusia (WEINSTEIN, 1999). 
b) Tempo de trabalho na ocupação igual ou superior a três anos, porque a PAIR inicia-se em média a partir de três anos de exposição (Comitê Nacional de Ruído e Conservação Auditiva 1999).

Dos 106 trabalhadores avaliados, $63(59,4 \%)$ foram classificados como portadores de PAIR.

\subsubsection{Avaliação das dificuldades de comunicação}

Para a identificação de trabalhadores com dificuldades de comunicação foi aplicado o questionário sobre percepção de handicap, HHIA (Anexo 3). O trabalhador respondia ao HHIA antes de ter acesso ao resultado da avaliação audiológica. Foi solicitado que ele lesse as perguntas e escolhesse uma das alternativas para cada uma, esclarecendo que poderia solicitar ajuda, se necessário.

As respostas são classificadas de acordo com um valor determinado para cada alternativa. A alternativa SIM tem o valor 4 , a alternativa $N A \tilde{O}$ tem valor 0 e a alternativa ALGUMAS VEZES tem valor 2, de forma que, se 0 trabalhador responder SIM às 25 perguntas que integram o questionário, seu percentual de percepção de handicap corresponderá à 100\%. Da somatória desses valores, teremos então um percentual total, classificado como:

0: ausência de percepçāo de handicap

2 a $16 \%$ : percepção leve de handicap

18 a $42 \%$ : percepção moderada de handicap

$>$ 42\% : percepção severa de handicap

$\mathrm{O}$ total de trabalhadores que responderam ao HHIA foi de 80 . Este instrumento foi utilizado também como forma de avaliação da intervenção proposta nesse estudo, sendo reaplicado após 5 meses da realização dos grupos, compostos por 33 trabalhadores.

\subsubsection{Identificação das representações sociais}

Com o objetivo de melhor compreender o significado da surdez e suas relações com a comunicação e com o trabalho, adotamos a teoria das 
Representaçōes Sociais, utilizando a técnica de evocaçōes livres (ABRIC, 1998), a partir de três termos indutores - surdez, comunicação e surdez e trabalho. Os motoristas escreviam ou falavam ao pesquisador as primeiras cinco palavras ou expressões que thes vinham à mente após a leitura ou a escuta do termo. Este instrumento foi utilizado também como forma de avaliação da intervenção proposta nesse estudo, sendo reaplicado após 7 meses da realização dos grupos, compostos por 33 trabalhadores.

\subsubsection{Método de intervenção educativo-terapêutica}

Ao término das etapas anteriores, foi possível selecionar os indivíduos adequados aos critérios de participação nos grupos, quais sejam ser portador de PAIR, em qualquer grau e ter percepção de handicap (percentual do HHIA $>0$ ). Pretendia-se, inicialmente, que esses grupos fossem montados de acordo com o grau de severidade das dificuldades avaliadas. Entretanto, as dificuldades operacionais para a montagem dos grupos, levaram a que o critério fosse a disponibilidade de horário dos motoristas.

$\mathrm{Na}$ empresa $\mathrm{A}$ os grupos foram realizados na própria empresa, em espaço destinado a treinamentos. Os dias e horários foram escolhidos pela empresa, de acordo com sua conveniência. Os componentes do grupo foram convocados pelo encarregado do setor tráfego. Os grupos foram realizados fora do horário de trabalho, por isso, julgou-se correto que os motoristas recebessem pagamento por aquele período, como hora extra.

Foram realizados três grupos. O primeiro (GRUPO 1) teve a duraçăo de três encontros, com aproximadamente 1 hora cada, no período da manhã, antes da entrada no trabalho. Foram convidados 18 motoristas e compareceram 10. Após a apresentação inicial, o grupo não concordou que fosse feita a gravação. Havia um clima de desconfiança, pelo fato de estarmos no espaço da empresa. Náo foi possivel avaliar se havia, entre os componentes do grupo, alguém escolhido pela empresa para "vigiar" as 
pessoas e o que era dito. Respeitando a decisão do grupo, não foi feita gravação, apenas anotações.

O segundo grupo (GRUPO 2), também foi realizado em três encontros, com o tempo de duração de aproximadamente 1 hora, no periodo da manhã, antes da entrada no trabalho. Foram chamados 20 motoristas e compareceram 12. Nesse grupo foi possível fazer a gravação.

O terceiro grupo (GRUPO 3), foi composto por 11 motoristas, sendo que 20 haviam sido chamados. Houve dificuldade em relação ao horário, que era após a jornada de trabalho, que nesse grupo era das 5 às 14horas. Eles estavam cansados e com sono, pois acordam entre 3 e 4 horas da manhã.

O grupo de trabalhadores da empresa $B$ foi realizado no CEREST. Foram chamados 24 motoristas e compareceram 12. Eles precisavam de comprovação de presença e temiam perder o dia por terem comparecido ao grupo. Consideramos que, nesse caso, seria improvável o comparecimento dos trabalhadores em outros dois encontros, portanto, decidimos priorizar algumas questões do conteúdo e fazer somente um encontro (grupo 4). Dada a limitação do tempo para a realização da pesquisa, não pudemos pensar em alternativas, por isso, esse grupo não foi incluído na análise comparativa do HHIA. Entretanto, suas contribuições para a compreensão do motorista e de seu trabalho, foram utilizadas na análise.

O conteúdo geral desenvolvido nos grupos baseia-se no trabalho de GETTY e HĖTU (1991), composto pelas etapas: discussão da natureza do problema auditivo, informações sobre amplificação sonora, aceitação da dificuldade, motivação para a reabilitação $e$ aplicação de técnicas comunicativas. A metodologia de trabalho no grupo foi planejada de acordo com os pressupostos da educação em saúde. O conteúdo especifico planejado é mostrado na Tabela 5 seguinte: 
Tabela 6 - Conteúdo especifico planejado

\begin{tabular}{c|c|c}
\hline $1^{\circ}$ encontro & $2^{\circ}$ encontro & $3^{\circ}$ encontro \\
\hline - Relação saúde- & - Possibilidades & - Adequação de hábitos: \\
trabalho & - Aceitação & em casa, no trabalho e \\
- Ruído e seus efeitos à & - Técnicas & no lazer \\
saúde & comunicativas AASI & \\
\hline
\end{tabular}

\section{$1^{\circ}$ encontro}

- Apresentação inicial: inclui a apresentação da pesquisadora e da proposta do grupo. Esclarece seus objetivos, o tempo de duração, os critérios para a composição do grupo, deixando claro que as informaçōes serão utilizadas para a pesquisa, mas as pessoas não serão identificadas. Solicita-se permissão para gravação do grupo.

- Apresentação dos componentes: feita através de dinâmica específica, na qual uma pessoa deve apresentar outra, por nome, dizendo também seu apelido (se houver) e descrevendo alguma característica dela. $O$ objetivo dessa dinâmica é integrar o grupo, para que as pessoas sintam-se à vontade para fazer suas colocaçōes.

- Distribuição de revistas de saúde ocupacional, solicitando que os componentes escolhessem algumas profissões mostradas nas figuras, apontando possíveis problemas de saúde que essas pessoas poderiam ter, provocados pelo trabalho. Procuramos aqui, observar a percepção de risco do grupo.

- Após essa dinâmica, pergunta-se ao grupo por que existe risco à saúde no trabalho e se isso é uma condição inevitável. Essa discussão deve originar a próxima pergunta sobre como mudar essa situação (Como fazer para melhorar?).

- Retomávamos o início da discussão, falando agora sobre os riscos da profissão de motorista. O objetivo aqui é que aparecesse o fator de risco ruido, para iniciarmos a discussão específica.

- Para a sensibilização sobre o ruído, escolhemos uma dinâmica que solicita que os componentes pensem no que ouviram naquele dia, 
desde a hora que acordaram até agora. Algumas pessoas devem dizer 3 coisas boas e 3 coisas ruins que ouviram.

- Procuramos então trazer a definição de som e ruído através desses exemplos, associando os sons agradáveis com SOM e os desagradáveis com RUÍDO.

- Iniciamos então uma breve explicação sobre a fisiologia auditiva, para podermos explicar os efeitos do ruído sobre a audição primeiramente, e depois, sobre a saúde em geral.

- Terminamos o primeiro encontro com uma pergunta, que deverá ser respondida no próximo encontro: O que fazer para nos protegermos do ruído?

\section{$2^{\circ}$ encontro}

- Iniciamos retomando a pergunta do encontro anterior, tentando discutir que o ruído está presente em nossa vidas desde muito cedo, e que nos habituamos a ele, sem saber que pode estar prejudicando nossa saúde.

- Com o objetivo de trabalhar a aceitação da surdez, discutimos o que é ser surdo, qual é a imagem de surdo que as pessoas têm. Perguntamos: o que é ser surdo e o que um surdo pode e o que não pode fazer? Partindo da noção de surdo como o portador de uma surdez profunda, que não chegou a desenvolver linguagem oral, ou do idoso que já não compreende mais o que as pessoas dizem (por surdez associada à outras dificuldades, próprias da idade), chegamos ao portador de uma surdez parcial, que pode ter consequaencias mais ou menos graves, de acordo com a perda e com a forma de lidar com ela; que é o caso do portador de PAIR. Tentamos discutir que para podermos ter uma atitude positiva, que permita superar obstáculos em relação à surdez e suas limitações, precisamos necessariamente aceitar o fato de ser portador de surdez e compreender o que isso significa em nossa vida. 
- Então, passamos a listar os principais problemas, associando a melhor atitude possível. Por exemplo: Elevar o volume do rádio e da TV; ver TV no quarto; conversar com os familiares sobre o problema; ficar mais próximo da TV; evitar ruídos competitivos. Não compreender a mensagem: solicitar repetição, ficar de frente para o falante; ter atenção ao contexto; ter atenção às pistas visuais. Utilizamos uma dinâmica sobre comunicação, através de mímica, discutindo como se dá a comunicação. No trabalho: avisar as pessoas de sua dificuldade, solicitando que falem mais alto, ou mais próximo, pois há ruído competitivo; a empresa deve disponibilizar mecanismos de compensação do problema, como sinais visuais ao invés de sonoros; manutenção e vedação do motor; fixação de partes soltas, ônibus com motor traseiro.

- Entrega-se ao grupo um folheto de orientação sobre o ruído e seus efeitos à saúde, para ser visto junto com a família. O AASI: indicações, tipos, vantagens, desvantagens.

\section{$3^{\circ}$ encontro}

- Revisão do conteúdo trabalhado, retomando o tema surdez e repercussões na vida, formas de controle.

- Pedimos para que citem outras situações problemáticas que eles vivem em função da surdez, e procuramos, junto com o grupo, indicar caminhos que amenizem esses problemas.

- Perguntamos sobre que tipo de atitude eles pretendem tomar ou já começaram, a respeito da proteção contra o ruido.

- Discutimos dúvidas que tenham surgido na leitura do material junto com a familia.

- O que é mais fácil e que é mais difícil de modificar para ter uma melhor qualidade de vida apesar dos problemas de comunicação?

- Abrir possibilidade de retorno para aconselhamento individual. 
- Discussão aberta no grupo, tentando observar o que eles concluem do grupo.

\subsubsection{Análise dos grupos}

Como finalização do trabalho, propusemos aos trabalhadores um novo encontro, após aproximadamente 120 dias, para resgate das discussōes realizadas, verificando se eles se lembravam das discussões e se tinham alguma dúvida.

Esse encontro funcionaria como momento de avaliação do trabalho em grupo, por meio de novo preenchimento do HHIA, para a comparação das respostas, verificando tanto o aumento ou redução de percepção de handicap, como a variação de respostas intra-questionário.

Espera-se que a intervenção terapêutica provoque um aumento da percepção de handicap, pois isso significa reconhecer a existência do problema e suas conseqüências, mas ao menos tempo uma redução de dificuldades, pela utilização das estratégias discutidas e pela compreensão das limitações e das possibilidades do portador de PAIR. A análise das respostas intra-questionários, possibilitará a análise de mudança de comportamento diante das dificuldades percebidas.

Os dados coletados pela técnica da evocação livre (teoria das representaçōes sociais) são analisados quantitativamente por meio do programa Evoc-Ensemble (SÁ 1998), que determina a freqüência de aparecimento do termo, assim como a ordem de evocaçăo do termo em relação aos demais. Os resultados são colocados em um quadro de quatro casas, separando os elementos do núcleo central, que são mais freqüentes e mais prontamente evocados (quadrante superior esquerdo), dos elementos do núcleo periférico, menos freqüentes e menos prontamente evocados (quadrante inferior esquerdo).

A comparação dos resultados obtidos nas evocações anteriores e posteriores ao grupo, possibilitaria observar se a intervenção do grupo provocou aiguma mudança nas representações. 


\section{QUESTÕES ÉTICAS}

O procedimento da pesquisa seguiu os princípios éticos preconizados pelo Conselho Nacional de Saúde. A participação dos motoristas, a cada etapa da pesquisa, foi precedida por uma explicação oral sobre a mesma, enfatizando-se a não obrigatoriedade de participação. Além disso, foi apresentado um Termo de Consentimento, com as explicações globais do estudo, por escrito, para que os motoristas pudessem optar por sua participação ou não na pesquisa. Esse termo está apresentado no Anexo 4. 


\section{RESULTADOS}

Foram realizadas 106 avaliações audiológicas. Dessa população, 80 trabalhadores responderam ao questionário de percepção de handicap (HHIA). Entre os $\mathbf{8 0}$ trabalhadores com avaliação audiológica e resultado do HHIA, foram convidados para os grupos, aqueles portadores de PAIR, em qualquer grau e com percepção de handicap em qualquer grau, perfazendo um total de 37. Compareceram para os grupos, 33 trabalhadores.

Serão apresentados, a seguir, os resultados dessas avaliações.

\subsection{Avaliação audiológica}

Os resultados da avaliação audiológica, realizada em uma população de 106 motoristas de ônibus, apresentam a seguinte distribuição:

Tabela 7 - Distribuição da população estudada, segundo situação auditiva

\begin{tabular}{c|c|c|c}
\hline Situação auditiva & N & $\%$ & \% acumulado \\
\hline Grau 0 & 43 & 40,6 & 40,6 \\
PAIR & 63 & 59,4 & 100 \\
\hline Total & 106 & 100 & \\
\hline
\end{tabular}




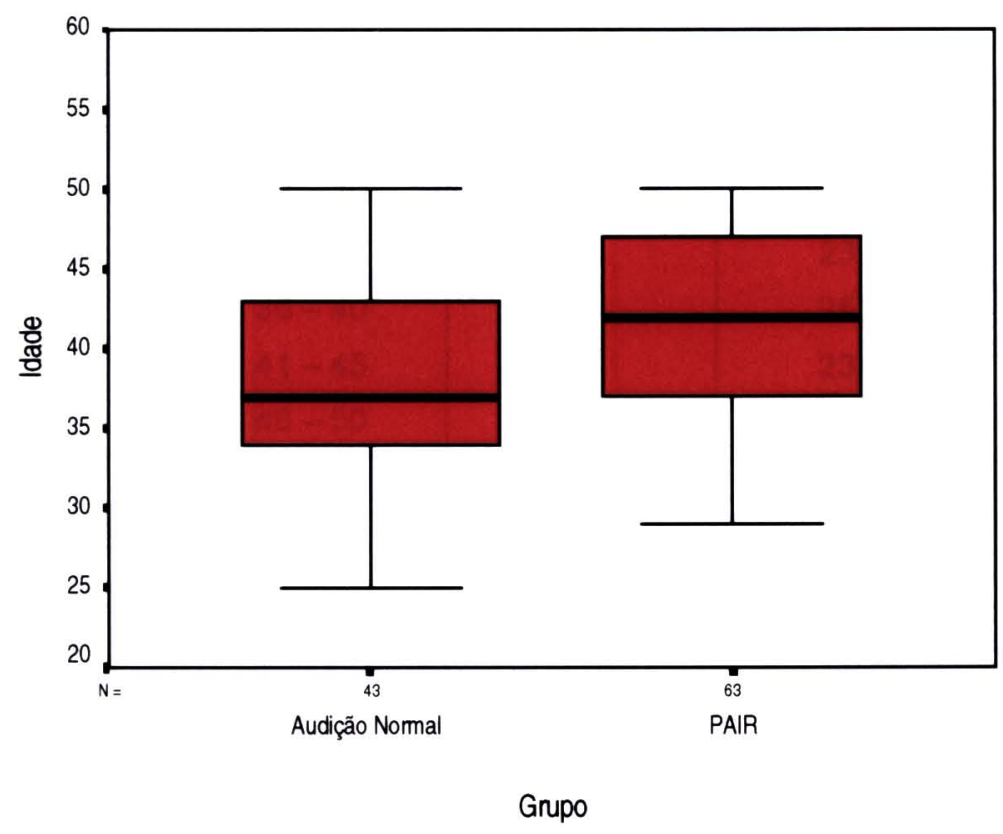

Figura 5 - Comparação entre as idades do grupo AUDIÇÃO NORMAL e PAIR.

* Diferença estatisticamente significante ao nível de $1 \%(p<0,01)$

Da população avaliada, $59,4 \%$ é portadora de PAIR. A distribuição dessa população, segundo o grau de perda auditiva, idade e tempo de exposição é apresentada na Tabela 7:

Tabela 8 - Distribuição do grupo PAIR, segundo grau de perda auditiva.

\begin{tabular}{c|c|c|c}
\hline $\begin{array}{c}\text { Grau de perda } \\
\text { auditiva }\end{array}$ & $\mathrm{N}$ & $\%$ & \% acumulado \\
\hline Grau 1 & 35 & 55,6 & 55,6 \\
Grau 2 & 8 & 12,7 & 68,3 \\
Grau 3 & 4 & 6,3 & 74,6 \\
Grau 4 & 3 & 4,8 & 79,4 \\
Grau 5 & 4 & 6,3 & 85,7 \\
Grau 6 & 9 & 14,3 & 100 \\
\hline Total & 63 & 100 & \\
\hline
\end{tabular}


Tabela 9 - Distribuição da população estudada, de acordo com a situação auditiva, segundo faixa etária.

\begin{tabular}{c|c|c|c|c}
\hline Situação Auditiva & Faixa etária & $\mathbf{N}$ & \% & \% acumulado \\
\hline Grau 0 & $25-30$ & 5 & 11,6 & 11,6 \\
& $31-35$ & 10 & 23,3 & 34,9 \\
& $36-40$ & 11 & 25,6 & 60,5 \\
& $41-45$ & 10 & 23,3 & 83,7 \\
& $46-50$ & 7 & 16,3 & 100 \\
\hline Graus 1 a 6 & Total & 43 & 100 & \\
& $25-30$ & 3 & 4,8 & 4,8 \\
& $31-35$ & 4 & 6,3 & 11,1 \\
& $36-40$ & 21 & 33,3 & 44,4 \\
& $41-45$ & 14 & 22,2 & 66,7 \\
& $46-50$ & 21 & 33,3 & 100 \\
\hline
\end{tabular}

Tabela 10 - Distribuição da população estudada, de acordo com a situação auditiva, segundo tempo de exposição.

\begin{tabular}{c|c|c|c|c}
\hline Situação Auditiva & $\begin{array}{c}\text { Tempo de } \\
\text { exposição }\end{array}$ & $\mathbf{N}$ & $\%$ & \% acumulado \\
\hline Grau 0 & $1-5$ & 2 & 4,7 & 4,7 \\
& $6-10$ & 12 & 27,9 & 32,6 \\
& $11-15$ & 13 & 30,2 & 62,8 \\
& $16-20$ & 9 & 20,9 & 83,7 \\
& $21-25$ & 6 & 14,0 & 97,7 \\
& $26-30$ & 1 & 2,3 & 100 \\
\hline Graus 1 a 6 & Total & 43 & 100 & \\
& $1-5$ & 2 & 3,2 & 3,2 \\
& $6-10$ & 4 & 6,3 & 9,5 \\
& $11-15$ & 21 & 33,3 & 42,9 \\
& $16-20$ & 13 & 20,6 & 63,5 \\
& $21-25$ & 16 & 25,4 & 88,9 \\
& $26-30$ & 6 & 9,5 & 98,4 \\
& $31-35$ & 1 & 1,6 & 100 \\
\hline
\end{tabular}




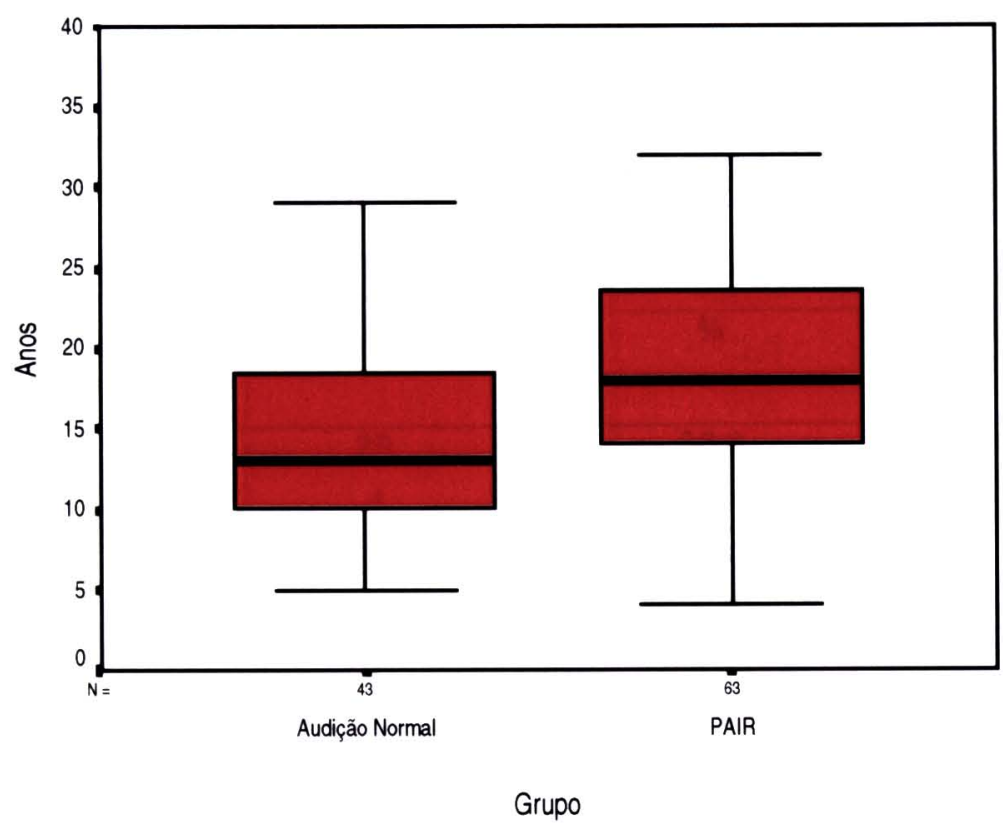

Figura 6 - Comparação do tempo de exposição dos grupos AUDIÇÃo NORMAL E PAIR.

* Diferença estatisticamente significante ao nível de $1 \%(p<0,01)$

Observa-se que a maioria da população tem perda auditiva no grau 1 , seguido pelo 6 , com $14,3 \%$. Nos dois grupos, na faixa etária mais prevalente está entre 36 e 40 anos. Na comparação da variável idade entre o grupo com audição normal e o grupo com PAIR, o percentual acumulado até a faixa entre 36 e 40 anos, indica que o grupo que compõem o grau 0 , é mais jovem $(60,5 \%)$ do que o grupo com PAIR $(44,4 \%)$. Em relação ao tempo de exposição, ambos os grupos apresentam maior concentração na faixa entre 11 e 15 anos de exposição, sendo que o grupo no grau 0 tem menor tempo de exposição (62,8\% até a faixa entre 11 e 15 anos), que o grupo com PAIR.

\subsection{Avaliação da percepção de handicap}

São apresentados agora, os dados relativos a aplicação do HHIA $(\mathrm{N}=80)$, para avaliação da percepção de handicap, por percentual de 
percepção isolado e categorizado em grau de severidade, independentemente da situação auditiva.

Tabela 11 - Distribuição da população estudada, segundo percentual de percepção de handicap.

\begin{tabular}{c|c|c|c}
\hline $\begin{array}{c}\text { \% de percepçăo de } \\
\text { handicap (HHIA) }\end{array}$ & N & $\%$ & \% acumulado \\
\hline 0 & 29 & 36,3 & 36,3 \\
2 & 4 & 5,0 & 41,3 \\
4 & 8 & 10,0 & 51,3 \\
6 & 3 & 3,8 & 55,0 \\
8 & 7 & 8,8 & 63,8 \\
10 & 4 & 5,0 & 68,8 \\
12 & 4 & 5,0 & 73,8 \\
14 & 3 & 3,8 & 77,5 \\
16 & 2 & 2,5 & 80,0 \\
18 & 1 & 1,3 & 81,3 \\
20 & 2 & 2,5 & 83,8 \\
22 & 1 & 1,3 & 85,0 \\
28 & 1 & 1,3 & 86,3 \\
30 & 3 & 3,8 & 90,0 \\
32 & 1 & 1,3 & 91,3 \\
42 & 1 & 1,3 & 92,5 \\
44 & 1 & 1,3 & 93,8 \\
56 & 2 & 2,5 & 96,3 \\
60 & 1 & 1,3 & 97,5 \\
98 & 1 & 1,3 & 98,8 \\
100 & 10 & 1,3 & 100 \\
\hline Total & & & \\
\hline & & & \\
\hline
\end{tabular}


Tabela 12 - Distribuição da população estudada, por graus de percepção de handicap.

\begin{tabular}{c|c|c|c}
\hline $\begin{array}{c}\text { Graus de percepção de } \\
\text { handicap }\end{array}$ & $\mathrm{n}$ & $\%$ & \% acumulado \\
\hline Sem percepçăo & 29 & 36,3 & 36,3 \\
Leve $(2-16)$ & 35 & 43,8 & 80,0 \\
Moderada( 18-42) & 10 & 12,5 & 92,5 \\
Severa( >42) & 6 & 7,5 & 100 \\
\hline Total & 80 & 100 & \\
\hline
\end{tabular}

Tabela 13 - Distribuição da população com percepção de handicap, segundo grau.

\begin{tabular}{c|c|c|c}
\hline $\begin{array}{c}\text { Graus de percepçáo de } \\
\text { handicap }\end{array}$ & $n$ & $\%$ & \% acumulado \\
\hline Leve $(2-16)$ & 35 & 68,6 & 68,6 \\
Moderada( 18-42) & 10 & 19,6 & 88,2 \\
Severa( >42) & 6 & 11,8 & 100 \\
\hline Total & 51 & 100 & \\
\hline
\end{tabular}

Os graus de percepção isolados onde aparece maior freqüência de resposta são o de $4 \%(10,0 \%)$, seguido pelo de $8 \%(8,8 \%)$. Observa-se que $36,3 \%$ da população estudada, não apresenta percepção de handicap e, entre a população que o refere (51 sujeitos), $68,6 \%$ apresenta percepção de handicap em grau leve.

\subsection{Avaliação auditiva e avaliação da percepção de handicap}

Quando relacionamos as variáveis situação auditiva e percepção de handicap, nos 80 indivíduos que responderam ao questionário HHIA, temos os seguintes resultados: 
Tabela 14 - Distribuição da população estudada, por situação auditiva, segundo percepção de handicap.

\begin{tabular}{c|c|c|c|c}
\hline $\begin{array}{c}\text { Situação } \\
\text { Auditiva }\end{array}$ & $\begin{array}{c}\text { Graus de percepção } \\
\text { de handicap }\end{array}$ & $\mathrm{N}$ & $\%$ & \% acumulado \\
\hline Grau 0 & Sem percepçåo & 16 & 53,3 & 53,3 \\
& Leve (2-16) & 11 & 36,7 & 90,0 \\
& Moderada( 18-42) & 2 & 6,7 & 96,7 \\
& Severa( >42) & 1 & 3,3 & 100 \\
\hline & Total & 30 & 100 & \\
\hline Graus 1 a 6 & Sem percepçåo & 13 & 26,0 & 26,0 \\
\hline & Leve (2-16) & 24 & 48,0 & 74,0 \\
& Moderada( 18 -42) & 8 & 16,0 & 90,0 \\
& Severa( >42) & 5 & 10,0 & 100 \\
\hline & Total & 50 & 100 & \\
\hline
\end{tabular}

* A diferença entre os grupos é significativa

A população apresentada acima foi dividida, para análise, em subgrupos, de acordo com a situação auditiva e o grau de percepção de handicap $(\mathrm{N}=80)$, sendo:

- Audição Normal e HHIA =0, incluidos os sujeitos no grau 0 e sem percepção de handicap

- Audição Normal e HHIA $\neq 0$, incluídos os sujeitos no grau 0 e com percepção de handicap em qualquer grau de severidade.

- PAIR e HHIA = 0, incluídos os sujeitos com PAIR em qualquer grau de severidade e sem percepção de handicap

- PAIR e HHIA $\neq 0$, incluidos os sujeitos com PAIR e percepção de handicap em qualquer grau.

As próximas tabelas referem-se à distribuição da população estudada, em subgrupos, considerando-se a faixa etária e o tempo de exposição. 
Tabela 15 - Distribuição da população estudada, nos subgrupos, segundo situação auditiva e percentual de handicap.

\begin{tabular}{c|c|c|c}
\hline Subgrupos & $\mathrm{N}$ & $\%$ & \% acumulado \\
\hline Aud. NI e HHIA $=0$ & 16 & 20,0 & 20,0 \\
Aud. NI e HHIA $\neq 0$ & 14 & 17,5 & 37,5 \\
PAIR e HHIA =0 & 13 & 16,3 & 53,8 \\
PAIR e HHIA $\neq 0$ & 37 & 46,3 & 100 \\
\hline Total & 80 & 100 & \\
\hline
\end{tabular}

Tabela 16 - Distribuição da população estudada, dividida em subgrupos, por faixa etária.

\begin{tabular}{|c|c|c|c|c|}
\hline Subgrupo & Faixa etária & $\mathbf{N}$ & $\%$ & $\%$ acumulado \\
\hline \multirow[t]{6}{*}{ Aud. NI e HHIA $=0$} & $25-30$ & 2 & 12,5 & 12,5 \\
\hline & $31-35$ & 4 & 25,0 & 37,5 \\
\hline & $36-40$ & 3 & 18,8 & 56,3 \\
\hline & $41-45$ & 3 & 18,8 & 75,0 \\
\hline & $46-50$ & 4 & 25,0 & 100 \\
\hline & Total & 16 & 100 & \\
\hline \multirow[t]{6}{*}{ Aud. NI e HHIA $\neq 0$} & $25-30$ & 1 & 7,1 & 7,1 \\
\hline & $31-35$ & 3 & 21,4 & 28,6 \\
\hline & $36-40$ & 2 & 14,3 & 42,9 \\
\hline & $41-45$ & 6 & 42,9 & 85,7 \\
\hline & $46-50$ & 2 & 14,3 & 100 \\
\hline & Total & 14 & 100 & \\
\hline \multirow[t]{6}{*}{ PAIR e HHIA $=0$} & $25-30$ & 1 & 7,7 & 7,7 \\
\hline & $31-35$ & 1 & 7,7 & 15,4 \\
\hline & $36-40$ & 3 & 23,1 & 38,5 \\
\hline & $41-45$ & 5 & 38,5 & 76,9 \\
\hline & $46-50$ & 3 & 23,1 & 100 \\
\hline & Total & 13 & 100 & \\
\hline \multirow[t]{6}{*}{ PAIR e $H H I A \neq 0$} & $25-30$ & 1 & 2,7 & 2,7 \\
\hline & $31-35$ & 2 & 5,4 & 8,1 \\
\hline & $36-40$ & 13 & 35,1 & 43,2 \\
\hline & $41-45$ & 8 & 21,6 & 64,9 \\
\hline & $46-50$ & 13 & 35,1 & 100 \\
\hline & Total & 37 & 100 & \\
\hline
\end{tabular}




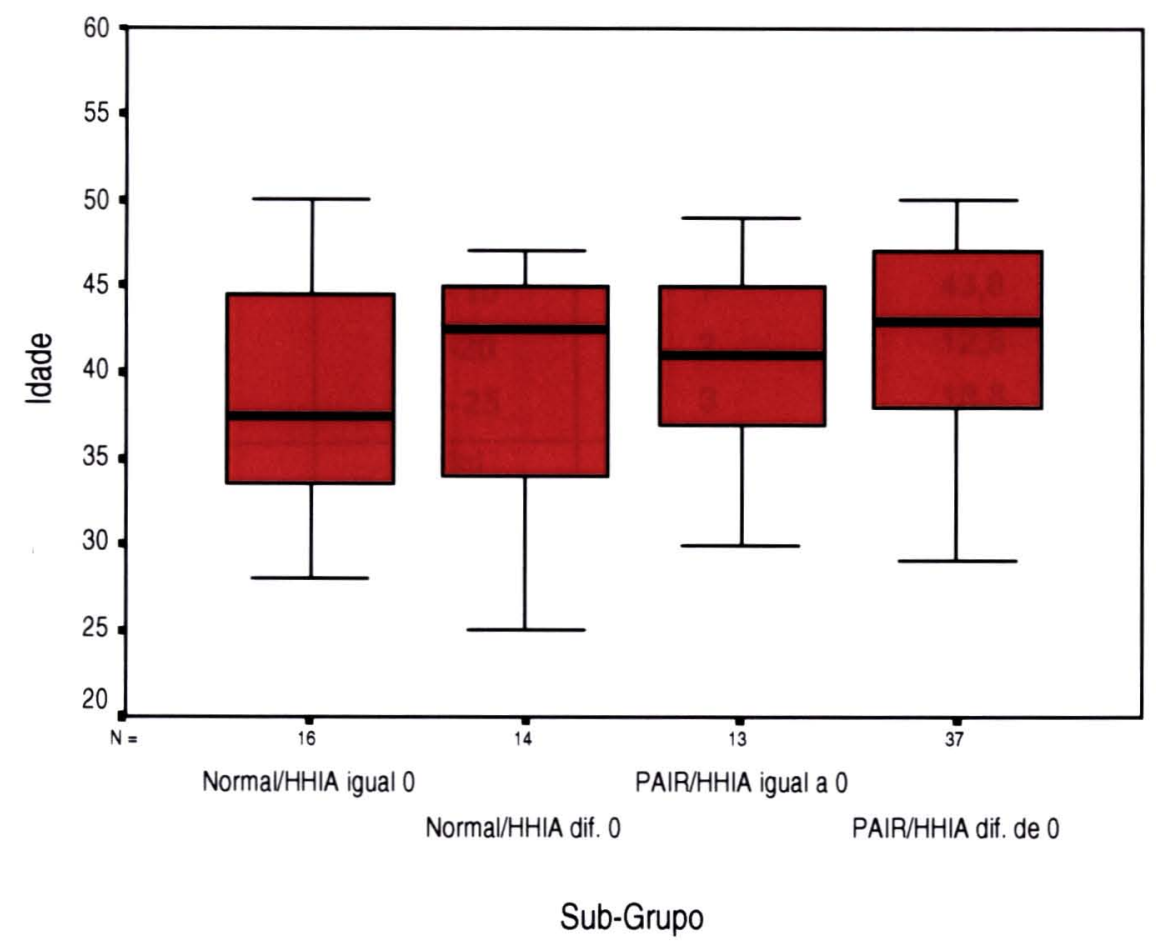

Figura 7 - Comparação entre as idades da população estudada, dividida em subgrupos.

* Não foi detectado diferença estatisticamente significante $(p>0,05)$ 
Tabela 17 - Distribuição da população estudada, em subgrupos, segundo tempo de exposição.

\begin{tabular}{|c|c|c|c|c|}
\hline Subgrupo & $\begin{array}{l}\text { Tempo de } \\
\text { exposição }\end{array}$ & $\mathbf{N}$ & $\%$ & $\%$ acumulado \\
\hline \multirow[t]{5}{*}{ Aud. Ni e HHIA $=0$} & $6-10$ & 4 & 25,0 & 25,0 \\
\hline & $11-15$ & 7 & 43,8 & 68,8 \\
\hline & $16-20$ & 2 & 12,5 & 81,3 \\
\hline & $21-25$ & 3 & 18,8 & 100 \\
\hline & Total & 16 & 100 & \\
\hline \multirow[t]{7}{*}{ Aud. NI e $\mathrm{HHIA} \neq 0$} & $1-5$ & 1 & 7,1 & 7,1 \\
\hline & $6-10$ & 3 & 21,4 & 28,6 \\
\hline & $11-15$ & 3 & 21,4 & 50,0 \\
\hline & $16-20$ & 3 & 21,4 & 71,4 \\
\hline & $21-25$ & 3 & 21,4 & 92,9 \\
\hline & $26-30$ & 1 & 7,1 & 100 \\
\hline & Total & 14 & 100 & \\
\hline \multirow[t]{6}{*}{ PAIR e HHIA $=0$} & $1-5$ & 1 & 7,7 & 7,7 \\
\hline & $11-15$ & 6 & 46,2 & 53,8 \\
\hline & $16-20$ & 1 & 7,7 & 61,5 \\
\hline & $21-25$ & 4 & 30,8 & 92,3 \\
\hline & $26-30$ & 1 & 7,7 & 100 \\
\hline & Total & 13 & 100 & \\
\hline \multirow[t]{7}{*}{ PAIR e $H H I A \neq 0$} & $1-5$ & 1 & 2,7 & 2,7 \\
\hline & $6-10$ & 3 & 8,1 & 10,8 \\
\hline & $11-15$ & 10 & 27,0 & 37,8 \\
\hline & $16-20$ & 9 & 24,3 & 62,2 \\
\hline & $21-25$ & 10 & 27,0 & 89,2 \\
\hline & $26-30$ & 4 & 10,8 & 100 \\
\hline & Total & 37 & 100 & \\
\hline
\end{tabular}




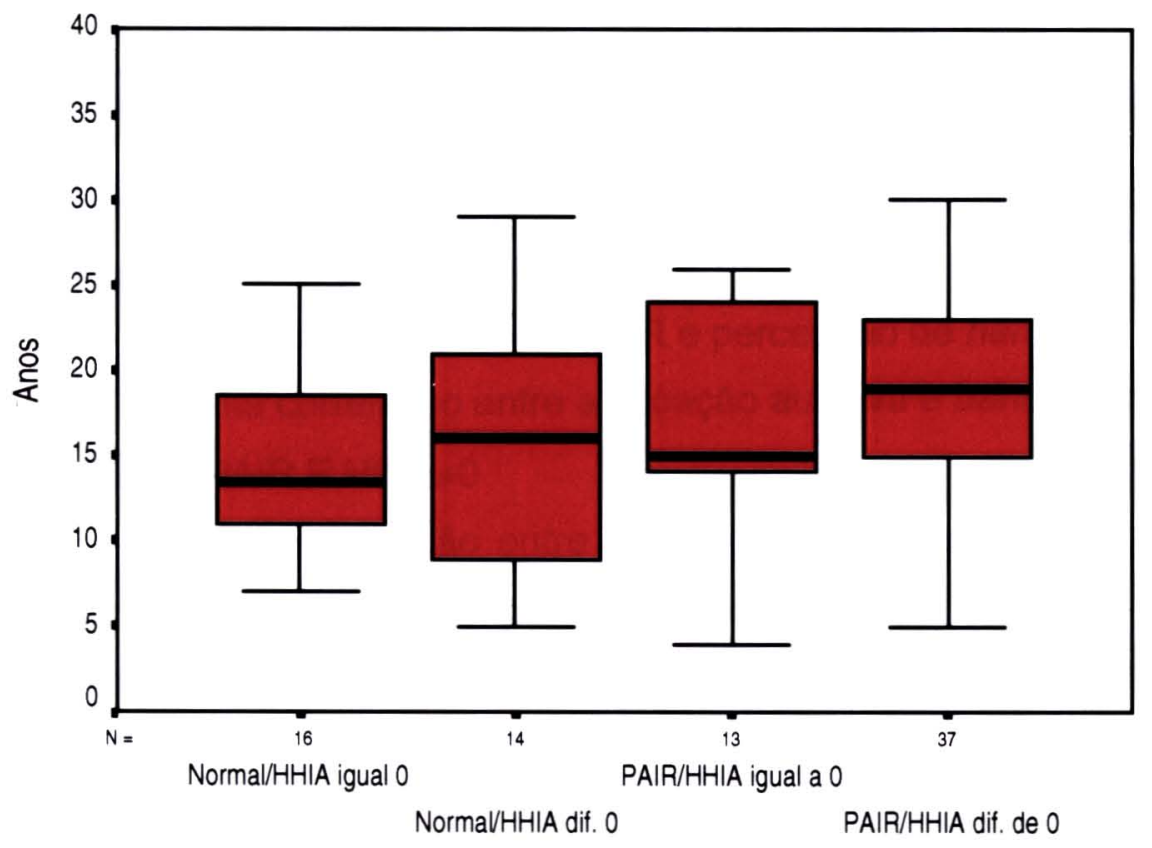

Sub-Grupo

Figura 8 - Comparação do tempo de exposição da população estudada, dividida em subgrupos.

* Não foi detectado diferença estatisticamente significante $(p>0,05)$

Ocorre percepção de handicap mesmo em quem possui audição normal, seno distribuída em $36,7 \%$ grau de percepção leve, $6,7 \%$ moderada e 3,3\% severa. Entre o grupo com PAIR, $74 \%$ tem algum grau de percepção de handicap, distribuído em $48 \%$ leve, $16 \%$ moderada e $10 \%$ severa.

$\mathrm{Na}$ análise por subgrupos, observamos que o subgrupo AUDIÇÃO NORMAL E HHIA $=0$, é o mais jovem, seguido pelo PAIR E HHIA $\neq 0$, enquanto os subgrupos AUDIÇÃO NORMAL E HHIA $\neq 0$ E PAIR E HHIA=0, concentram-se na faixa etária entre 41 a 45 anos.

Não houve diferença estatisticamente significante na comparação das medianas de idade e tempo de exposição dos subgrupos. 


\subsection{Análises de correlação}

- Há correlação positiva entre as variáveis idade e tempo de exposição nos sub-grupos AUDIÇÃo NORMAL E HHIA=0, AUDIÇÃO NORMAL E HHIA $\neq 0$ E PAIR E HHIA $\neq 0$.

- Há correlação positiva entre a situação auditiva e o handicap codificado da população estudada.

- Não há correlação entre PAIR e percepção de handicap

- Não há correlação entre a situação auditiva e handicap para o subgrupo PAIR E HHIA $\neq 0$

- Não há correlação entre a situação auditiva e handicap, no subgrupo PAIR E HHIA $\neq 0$, para os graus moderado e severo.

\subsection{Avaliação do grupo}

\subsubsection{Descrição dos resultados}

Descreveremos abaixo os resultados obtidos nos grupos, divididos por empresa. Optamos por dividir a análise em temas, baseado no trabalho de GETTY e HËTU (1991), que proporcionassem uma visão mais clara do andamento do grupo. Os temas são:

a) Conteúdo e Método de trabalho

b) Problemas identificados e conseqüenncias relacionadas

c) Formas de intervenção

d) Observações gerais

\section{Conteúdo e método de trabalho}

No grupo 1, o conteúdo, foi seguido integralmente, de acordo com o programado, nos três encontros. Em relação ao método, foi também o proposto no planejamento. Não houve necessidade de mudanças, apenas alguns ajustes no decorrer dos encontros. 
No grupo 2, o conteúdo programado sofreu alteraçōes, pois houve pouco interesse na fisiopatologia do ruído e um enorme interesse pelas questões trabalhistas das doenças ocupacionais, o papel do sindicato e do SUS. Em relação ao método, também só sofreu pequenos ajustes como a antecipação de alguma dinâmica.

No grupo 3, houve problemas em relação ao horário de sua realização. Do primeiro para o segundo encontro, houve muito atraso e faltas (3), por isso, modificamos a dinåmica, reduzindo o conteúdo, para que ele fosse finalizado naquele mesmo encontro. $O$ método foi mantido, de acordo com o conteúdo trabalhado.

No grupo 4, no qual ocorreu um só encontro, todo conteúdo foi reduzido (tivemos que excluir atividades como a dinâmica sobre comunicação), de acordo com os interesses mostrados pelos trabalhadores, e o método foi mantido de acordo com o conteúdo trabalhado.

Ainda em relação ao conteúdo, destacamos algumas falas, categorizadas por assunto, provocados pelas dinâmicas ou que surgiram espontaneamente, as quais consideramos fundamentais para a nossa compreensão do motorista de ônibus.

- Identificação de riscos em profissões diversas (dinâmica na qual é solicitado ao trabalhador que escolha uma figura na revista e indique seus riscos à saúde):

1 - Pintor de paredes:

"Inalar produtos"

"Precisava de uma proteção"

"Tem o perigo de cair, ficar pendurado"

2 - Lavrador:

"Contaminação"

"Forçar as costas"

"O maior risco é trabalhar com os produtos agrícolas" 
"Trabalhar nessas máquinas que não tem proteção, tem muito barulho"

3 - Professor:

"Desgasta. Fica nervoso. Tem problemas emocionais. Desgasta mentalmente".

"Depende da pessoa dá dor nas pernas."

"Tem a inalação do giz"

"Tem a carga horária do professor"

"O salário é muito baixo"

4 - Minerador de carvão:

"Dentro da mina de carvão tem falta de oxigenação, pode provocar problemas pulmonares. $E$ barulho demais, vai provocar problema no tímpano".

"Tem temperatura"

"Muita umidade. É muito desgastante".

"E também é muito mal remunerado."

"Esse vai ter problemas de audição, problemas pulmonares, porque a respiração falta para ele, não tem ar."

Os trabalhadores conseguem identificar, com facilidade, os fatores de risco gerais e específicos de cada profissão escolhida.

- Identificação de riscos no trabalho de motorista de ônibus (discutidos a partir de pergunta para o grupo):

"E quais são os riscos para a saúde de um motorista de ônibus?"

"Estresse"
"Cansaço"
"É o trânsito, passageiros que ficam discutindo dentro do ônibus." 
"É a vedação do motor"

"É o câmbio duro"

"Barulho"

"Provoca calor."

"Conheço um cara que trabalhava comigo. Ele estava viajando no meio da madrugada e estourou um pneu traseiro. Só que, na hora que estourou o pneu, foi tudo para cima. Com o deslocamento do ar, arrancou o pára-lama, arrancou um banco e deixou a pessoa paraplégica."

"Estourou um pneu e soltou o ar para cima e atingiu uma senhora que estava sentada lá atrás."

"Tem caras estressados, nervosos".

"O pior risco é o estresse, ele sai estressado".

"Para mim é a solidão. Solidão é triste".

"Quando eu entrei aqui eu estava com quarenta e dois. Eu não tinha problema de audição nem de visão. Hoje estou vendo que eu tenho dificuldade em ouvir e enxergar. Eu só não estou estressado quando estou com amigos. No trânsito, quando o cara está muito bravo, eu mando um beijinho para ele".

"Eu passei mal no volante. Eu fiquei muito nervoso. Foi acumulando, acumulando e minha pressão subiu. Foi traumático para mim. E olha que eu tenho pressão baixa. E eu estava em uma subida, que é uma coisa extremamente perigosa. $E$ ainda mais com o ônibus lotado. $E$ simplesmente foi acabando a minha condição de andar. Eu só lembrei de puxar o freio de estacionamento do ônibus e eu vi que estava vindo um ônibus e eu falei, pelo amor de Deus, me leva para um hospital que eu não agüento mais."

"É muita carona, muito malandro na rua. Às vezes você pode dar carona para alguém perigoso."

"As pessoas de idade e outras que tem carteirinhas tratam você como um (...) e fazem isso para você, com a carteira fechada e fazem assim para você. Mostram fechada. $E$ as pessoas de idade mal educadas, 
mal criadas. Se você vai falar alguma coisa: não olha na minha cara, que você não viu que eu tenho cabelo branco? Você não tem vergonha na cara que um você vai chegar um dia que (...) aí começa a história, um dia, outro dia, e você pára para pensar: eu năo sou empregado, eu sou escravo. Escravo dos carteirinhas."

"Eu trabalho no período noturno. Se ficar com luz (substituindo a campainha) na sua cara você não enxerga nada. Não dá certo. Dá vontade de quebrar o bicho."

"Às vezes sobe dois passageiros. Ele pergunta pra mim: passa no viaduto do chá? Eu falo: não. O outro está do lado dele e faz a mesma pergunta. Às vezes irrita. Eu já nem falo nada. Viro a cara para o lado e nem respondo..."

“Eu faço o dia todo o Eldorado. Depois das dezessete horas não tem mais um itinerário específico dizendo Sapopemba. Tem um itinerário misturado. Aí fica uma confusão. Tem passageiro que não sabe. Não é falha nossa, é falha de quem montou."

"Sai fumaça. Toda vez que vaza óleo, os olhos começam a ficar irritados."

"O pior problema da categoria é a má manutenção"

Os motoristas apontam como pior problema o estresse, que parece ser resultado dos inúmeros fatores de risco associados, como a má manutenção do ônibus que provoca ruído, calor, irritação nos olhos, acidentes, dores nas costas; enfrentamento de situações conflituosas com os passageiros, sem treinamento ou retaguarda da empresa; medo da violência, sem retaguarda da empresa, ou do serviço de segurança pública; trânsito caótico, desrespeito dos motoristas de carro; exigências da empresa em relação à necessidade de cumprimento de horário da viagem e responsabilização por acidentes.

- Fisiologia auditiva (a dinâmica consiste de aula expositiva sobre a fisiologia auditiva): 
"A audição e a voz é um conjunto. Se você não tem voz, é muito mais difícil para ouvir."

Há poucas idéias preconcebidas sobre a fisiologia auditiva. Não é assunto que gere curiosidade sem um estímulo adequado. Durante as explicaçōes, muito breves, demonstraram bastante interesse e fizeram perguntas genéricas, sobre tipos de problemas auditivos.

- Formas de intervenção (discussão sobre como melhorar as condiçőes de trabalho):

"O rodízio de veículos"

"Melhorou bem"

"Seria bem melhor se tivesse o rodízio de veículos o dia inteiro"

"Tem muitos carros que ficam encostados no canto da marginal esperando o horário"

"A carteirinha vai ser diferente".

"Ela vai ser eletrônica"

"Já vai vir com um magnético"

"É, já vai facilitar bastante"

"Tinha que criar um departamento que cuidasse só desses casos de estresse. Que pegasse essa pessoa e fizesse um trabalho que ela pudesse, sei lá, melhorar um pouco".

"Relaxar um pouco mais."

"Mas, às vezes é só trocar a borrachinha".

"Mexer no barulho, melhora o estresse"

"A campainha tinha que ser padrão".

"Tinham que sintonizar a luz. Tinha que ser em um lugar que você não precisasse levantar a cabeça."

Parece senso comum a questão da manutenção e de ajustes simples que, no entanto, não são feitos. É preocupante o fato de alguns motoristas utilizarem, por conta própria, protetores auditivos. Apesar disso demonstrar o 
incômodo provocado pelo ruído, os protetores são inadequados à função e não devem estar sendo utilizados corretamente, pois não há nenhum programa de orientação. Talvez fosse importante realizar pesquisa especifica sobre esse tema. Há solicitação de serviço de atenção à saúde mental.

- Ruído e seus efeitos à saúde:

"Afeta a audição"

"Dor de cabeça, crise nervosa"

"O problema é que dói a cabeça"

"Televisão alta demais. Só isso. A minha mulher reclama".

"Tem passageiros (...) tem que falar meio alto, mas tem passageiros que tem educação e quer falar baixinho, só que a gente não escuta”. "Às vezes um idoso começa a falar e você: é, é..".

"A gente escuta mas não processa. Para ser mais gentil, você: é, é..". "Tem gente que até fala: isso não dá para entender, não."

"Esse aqui geralmente vira a cara"

"O barulho? Dá pra controlar"

"É que o barulho (...) é o costume".

"O estresse é que faz mais barulho".

"Quando você reclama, está baixo, mas: estou ouvindo. Todo mundo está ouvindo, só você que está olhando. Aí: o que ele falou? Se a gente fala: aumenta um pouquinho? O quê? Está surdo?"

"Surdez é uma coisa que incomoda. A pessoa está se esforçando, mas é uma coisa que não é dela. Uma coisa é você ser surdo, outra coisa é você estar ficando surdo".

"É verdade, é diferente."

"E o Beethoven, ficou surdo por causa do barulho alto do piano?"

Parece haver um reconhecimento sobre os efeitos do ruído na audição, na saúde em geral e suas conseqüências, fundamentalmente em relação à comunicação. Eles apontam questōes como a culpa de ser surdo, 
a diferença entre o surdo que não ouve nada e o que ouve alguma coisa, e a incompreensão da família e amigos.

- Auto-imagem do motorista de ônibus:

"Precisa ter calma".

"Concentração".

"Tem que conhecer".

"Tem que ter atenção. Tem que ter cuidado."

"Treinamento".

"Bastante experiência."

"Saber entrar debaixo do carro para ver se o pneu está murcho".

"Uma dose de boa vontade. Se não tiver boa vontade você não sai."

"E habilidade".

"Tem que ter habilidade, tem que ter uma vista boa e tem que ouvir bem. São tantas coisas que tem que ter."

"Quando eu vou trabalhar, às vezes é mais pelo respeito que eu tenho por aquele passageiro. É aquele mesmo horário todos os dias. Às vezes o carro não está em boas condições, mas às vezes tem aquele passageiro que é seu, do seu horário, então você vai na boa vontade e vai fazer."

"Você não tem conceito com os usuários"

"Eu já fiz recursos humanos, direção defensiva. Eu já fiz tudo. Eu sei como tratar os passageiros. Mas os passageiros não sabem como tratar os motoristas. A vida deles depende de nós, dos motoristas. Eles não sabem disso."

Apesar de sentirem-se desvalorizados por todos, e isso provocar insegurança em relação à sua própria importância, eles conseguem identificar as habilidades necessárias para a realização do trabalho $e$, portanto, reconhecem seu valor profissional. 


\section{Problemas identificados e conseqüências relacionadas}

Essas questões foram semelhantes em todos os grupos, por isso serão apresentados de forma unificada e, classificados, de acordo com sua relação com o trabalho:

\section{1 - Relacionados ao trabalho:}

- Passageiros, como pedidos de carona, assalto, reclamações.

- Falta de manutenção dos ônibus, segundo os motoristas, frota bastante antiga: ruído, provocado pela falta de vedação do motor, normalmente dianteiro, carroceria solta, janelas que trepidam, portas sem ajuste, campainha muito alta ou com som estridente, passageiros que falam muito alto, trânsito; iluminação inadequada provocando reflexos nos olhos; bancos sem possibilidade de ajuste, pedais e volante "duros".

- Violência, como assaltos e brigas no trânsito.

- Trânsito, excesso de lombadas, multas irregulares, acidentes. A empresa orienta a não realização de boletim de ocorrência em caso de acidente, mas sim a tentativa de acordo entre os envolvidos. Caso o motorista seja considerado culpado, por uma comissão julgadora interna à empresa, ele deverá arcar com os custos do conserto dos veículos, ou indenização às vítimas ou familiares.

- Desrespeito ao motorista por parte de todos, começando pela própria empresa.

- Horários irregulares e jornadas extensas.

- Baixo salário.

- Constantes mudanças de chefia na empresa.

- Falta de apoio do sindicato dos condutores.

- Assistência médica precária.

- Dificuldade de compreensão de fala, não entendem o que colegas de trabalho ou passageiros falam. 
- Problemas de saúde decorrentes do trabalho como: perda de audição, lombalgia, hipertensão, nervosismo excessivo, esquecimento, zumbido, tontura. Houve várias referências sobre vontade de abandonar o ônibus, ou jogá-lo de uma ponte ou sobre um carro ou pessoa.

2. Não relacionados ao trabalho

- Necessidade de aumento de volume da TV e rádio, o que provoca isolamento, ou conflitos familiares.

- Dificuldade de compreensão de fala, o que provoca situações de conflito com a familia e amigos.

- Irritação com ruido excessivo.

- Os problemas de saúde referidos anteriormente (perda de audição, lombalgia, hipertensão, nervosismo excessivo, esquecimento, zumbido, tontura) interferem diretamente na qualidade de vida do indivíduo, dentro e fora do ambiente de trabalho.

\section{Formas de intervenção}

Algumas sugestões para a melhoria das condições de trabalho surgiram nos grupos, a partir da reflexão proposta, como:

- Campanha de valorização do motorista, junto a população.

- Reuniões com a manutenção, para discussão das condições do ônibus.

- Treinamento constante sobre o tratamento dos clientes.

Reuniōes para esclarecimentos gerais sobre a empresa (condiçōes financeiras, administrativas, recursos humanos, etc.).

- Avaliação das condições de segurança do trabalho dos motoristas.

- Avaliações de saúde adequadas aos riscos identificados.

- Acesso dos motoristas às informações sobre os riscos e condição de saúde. 
- Adequação das condições do ônibus para redução de ruído, o que é considerado simples, com a correta vedação do motor.

\subsubsection{Observaçōes gerais}

O comportamento das pessoas no grupo também foi bastante semelhante nos grupos da empresa A. Foi possível observar um bom relacionamento entre os motoristas. Todos se conhecem por nome e/ou apelido. Como a empresa não tem grande rotatividade, a maior parte dos motoristas tem um tempo de trabalho significativo (média de 10 anos de trabalho na empresa), o que lhes confere uma certa intimidade com a empresa. Todos parecem ter muita clareza de seus problemas. De acordo com os motoristas, as pessoas que assumem a direção da empresa só têm interesse político e não de desenvolvimento do trabalho, por isso não fazem mudanças efetivas para a melhoria das condições de trabalho.

O maior problema parece ser a falta de integração entre os diversos setores, principalmente o tráfego, a manutenção e os inspetores. Um não respeita o outro e cada um tem idéias sobre o trabalho do outro. Há uma enorme necessidade de melhoria da comunicação interna e também externa (junto à população). Esse problema organizacional paralisa ou reduz a eficácia de qualquer ação isolada, seja na saúde, segurança, ou outra área.

Os motoristas conseguem identificar vários problemas, mas se sentem impotentes para fazer qualquer modificação, pois consideram que não são ouvidos dentro da empresa.

Na empresa B, a situação é de medo do desemprego, pois as novas regras da SP-TRANS, de acordo com os motoristas, estão melhorando um pouco as condições de trabalho pela exigência de renovação da frota, maior fiscalização, sistema de catraca eletrônica, entre outros; mas as empresas contratadas, para manter o padrão exigido, estão cortando gastos por meio das demissões. O contato com esse grupo foi bem menor, e por isso, menos rico em todos os aspectos pesquisados. 


\subsection{Resultados da reaplicação do HHIA}

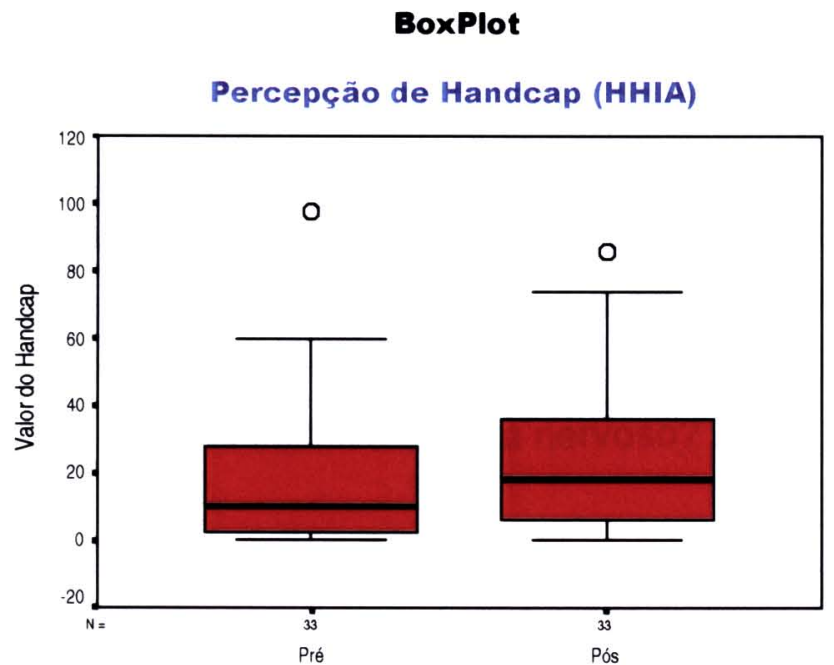

Figura 8 - Comparação entre os resultados das aplicações do HHIA pré e pós grupos.

*Há diferença estatisticamente significante $(p<0,05)$ entre os resultados da avaliação de percepção de handicap pré e pós grupos.

Tabela 17 - Distribuição das respostas obtidas pela população estudada, pré e pós grupo $(\mathrm{N}=825)$.

\begin{tabular}{c|c|c|c|c}
\hline Respostas & Pré & Grupo & Pós & Grupo \\
\hline & $\mathbf{N}$ & $\%$ & $\mathrm{~N}$ & $\%$ \\
\hline Sim & 122 & 14,8 & 127 & 15,4 \\
Não & 589 & 71,4 & 540 & 65,5 \\
Algumas Vezes & 95 & 11,5 & 158 & 19,1 \\
Não Respondeu & 19 & 2,3 & 0 & 0,0 \\
\hline Total & 825 & 100 & 825 & 100 \\
\hline
\end{tabular}

A comparação das respostas dos trabalhadores antes e depois da intervenção pelo grupo, indica diferença significativa. A maior variação das respostas ocorreu na alternativa ALGUMAS VEZES, o que pode indicar um início de reconhecimento ou identificação das dificuldades existentes, provocadas pela exposição ao ruído, após a intervenção do grupo. 
Em relação às perguntas que sofreram maior variação, sendo considerado o valor maior ou igual a cinco, foram as de n. 4, 9, 11, 12 . Dessas; três referem-se às sensaçőes relacionadas às dificuldades auditivas:

Questōes:

n. 4: Seu problema auditivo torna-o irritado?

n. 9: Você se sente prejudicado em funçăo do seu problema auditivo?

n. 11: Seu problema auditivo faz com que você tenha problemas para ouvir ou entender seus colegas de trabalho?

n. 12: Seu problema auditivo o torna nervoso?

\subsection{Resultados da análise das evocações}

Tabela 18 - Termo indutor: SURDEZ - Pré-grupo

Frequêência Média: 5; Freqüência Mínima: 2; Ordem Média de Evocação: 2,5

O.M.E.

$<2,5$

$\geq 2,5$

\begin{tabular}{|c|c|c|c|c|c|c|}
\hline \multirow{3}{*}{$\begin{array}{l}\text { Freq. } \\
\text { Med. }\end{array}$} & \multirow{3}{*}{$\begin{array}{c}\text { ELEMENTOS } \\
\text { CENTRAIS DA RS } \\
\text { barulho }\end{array}$} & F.Med. & O.M.E. & \multirow[b]{3}{*}{ Mudo } & F.Med. & O.M.E. \\
\hline & & & & & & \\
\hline & & 5 & 1,6 & & 5 & 2,6 \\
\hline \multirow[t]{2}{*}{$\geq 5$} & não ouvir & 15 & 1,7 & Tristeza & 5 & 2,8 \\
\hline & problema & 13 & 1,9 & & & \\
\hline \multirow{6}{*}{$<5$} & \multirow{6}{*}{$\begin{array}{c}\text { buzina } \\
\text { invalidez } \\
\text { não falar } \\
\text { som } \\
\text { surdo }\end{array}$} & & & \multirow{6}{*}{$\begin{array}{c}\text { ELEMENTOS } \\
\text { PERIFÉRICOS DA } \\
\text { RS } \\
\text { irritação } \\
\text { motor } \\
\text { não entende } \\
\text { problema para falar }\end{array}$} & & \\
\hline & & 2 & 2,0 & & 4 & 2,7 \\
\hline & & 3 & 1,5 & & 2 & 3,0 \\
\hline & & 2 & 2.0 & & 3 & 3,0 \\
\hline & & 2 & 2,0 & & 3 & 3,3 \\
\hline & & 4 & 1,2 & & & \\
\hline
\end{tabular}

O.M.E. =ordem média de evocação

$F$.Med.=freqüência média 
Tabela 19 - Termo indutor: SURDEZ - Pós-grupo

Freqüência Média: 5; Freqüência Mínima: 2; Ordem Média de Evocação: 2,4 O.M.E. $<2,4$ $\geq 2,4$

\begin{tabular}{|c|c|c|c|c|c|c|}
\hline Freq. & \multicolumn{3}{|c|}{ ELEMENTOS CENTRAIS DA RS } & \multirow[b]{2}{*}{$\begin{array}{l}\text { irritação } \\
\text { tristeza }\end{array}$} & \multirow[b]{2}{*}{$\begin{array}{l}6 \\
5\end{array}$} & \multirow[b]{2}{*}{$\begin{array}{l}2,500 \\
3,200\end{array}$} \\
\hline$\geq 5$ & $\begin{array}{l}\text { barulho } \\
\text { não-ouvir } \\
\text { problema }\end{array}$ & $\begin{array}{l}9 \\
13 \\
15\end{array}$ & $\begin{array}{l}2,111 \\
1,692 \\
2,133\end{array}$ & & & \\
\hline$<5$ & $\begin{array}{l}\text { invalidez } \\
\text { não entende } \\
\text { ouvido } \\
\text { quem não ouvir } \\
\text { surdo }\end{array}$ & $\begin{array}{l}3 \\
4 \\
2 \\
3 \\
2\end{array}$ & $\begin{array}{l}1,333 \\
1,750 \\
1,000 \\
1,333 \\
2,000\end{array}$ & $\begin{array}{l}\text { ELEMENTOS } \\
\text { motor } \\
\text { problemas }\end{array}$ & $\begin{array}{l}E R I \\
3 \\
2\end{array}$ & $\begin{array}{l}\text { DA RS } \\
2,667 \\
3,000\end{array}$ \\
\hline
\end{tabular}

Podemos observar que tanto os termos quanto sua distribuiçăo mantêm-se semelhantes no quadrante superior esquerdo (referente ao núcleo central) nas situações pré e pós grupo. Isso significa que não houve mudança nas representações com a intervenção do grupo.

Tabela 20 - Termo indutor: SURDEZ E TRABALHO - Pré-grupo Freqüência Média: 5; Freqüência Mínima: 2; Ordem Média de Evocação: 2,4 O.M.E. $<2,4 \quad \geq 2,4$

\begin{tabular}{|c|c|c|c|c|c|c|}
\hline Freq. & \multicolumn{3}{|c|}{ ELEMENTOS CENTRAIS DA RS } & \multirow[b]{2}{*}{$\begin{array}{l}\text { irritação } \\
\text { problema }\end{array}$} & \multirow[b]{2}{*}{$\begin{array}{l}6 \\
13\end{array}$} & \multirow[b]{2}{*}{$\begin{array}{l}2,667 \\
2,538\end{array}$} \\
\hline$\geq 5$ & motor & 6 & 2,000 & & & \\
\hline$<5$ & $\begin{array}{l}\text { barulho } \\
\text { barulho do motor } \\
\text { buzina } \\
\text { não combinam } \\
\text { passageiro }\end{array}$ & $\begin{array}{l}4 \\
3 \\
2 \\
4 \\
3\end{array}$ & $\begin{array}{l}1,500 \\
2,000 \\
1,500 \\
2,000 \\
1,667\end{array}$ & ELEMENTOS & $E \mathrm{RIC}$ & DA RS \\
\hline
\end{tabular}


Tabela 21 - Termo indutor: SURDEZ E TRABALHO - Pós-grupo

Freqüência Média: 5; Freqüência Mínima: 2; Ordem Média de Evocação: 2,3

O.M.E $<2,3$

$\geq 2,3$

\begin{tabular}{|c|c|c|c|c|c|c|}
\hline Freq. & \multicolumn{3}{|c|}{ ELEMENTOS CENTRAIS DA RS } & \multirow[b]{2}{*}{$\begin{array}{l}\text { irritação } \\
\text { motor }\end{array}$} & \multirow[b]{2}{*}{$\begin{array}{l}9 \\
5\end{array}$} & \multirow[b]{2}{*}{$\begin{array}{l}2,333 \\
2,400\end{array}$} \\
\hline$\geq 5$ & problema & 12 & 1,917 & & & \\
\hline$<5$ & $\begin{array}{l}\text { barulho } \\
\text { barulho do motor } \\
\text { motor do ônibus } \\
\text { não combinam }\end{array}$ & $\begin{array}{l}4 \\
2 \\
2 \\
2\end{array}$ & $\begin{array}{l}1,250 \\
1,500 \\
1,000 \\
1,500\end{array}$ & $\begin{array}{l}\text { ELEMEI } \\
\text { buzina } \\
\text { campainha } \\
\text { passageiro }\end{array}$ & $\begin{array}{r}\text { VIF } \\
2 \\
4 \\
2\end{array}$ & $\begin{array}{l}\text { COS } \\
2,500 \\
2,750 \\
3,500\end{array}$ \\
\hline
\end{tabular}

Apesar da análise ter sido prejudicada pela dispersão das palavras evocadas, foi possível observar que nesse caso, também não aparece diferença nas representações pré e pós-grupo, o que significa que a intervenção não modificou o núcleo central das representações.

No termo indutor, comunicação, houve muita dispersão das evocações, o que não permitiu a construção do quadrante.

É importante resgatarmos aqui, as evocações utilizadas pelos trabalhadores, que podem indicar o significado dado por eles, aos termos analisados.

1 - Surdez: barulho, não ouvir, problema. Essas palavras podem indicar que o trabalhador associa ruído e surdez, compreende surdez como ausência de audição e lhe dá um valor negativo.

2 - Comunicação: falar, problema, ouvir, gestos. Apesar da impossibilidade de construção do quadrante, podemos identificar as evocações mais freqüentes; elas associam comunicação à fala (linguagem oral), audição e gestos (linguagem gestual), mas também indica a existência de limitações ou problemas em relação à ela. 
3 - Surdez e trabalho: motor e problema como elementos centrais; buzina, campainha, passageiro, como elementos periféricos. Ao que parece, as evocações indicam a compreensão da relação surdez e trabalho como um fato, e buscam identificar suas origens. Também há um valor negativo nessa associação. 


\section{DISCUSSÃO}

A comunidade de surdos americanos năo se considera deficiente ou portadora de deficiência. Eles dizem que têm as mesmas capacidades dos ouvintes, diferindo apenas, na forma de comunicação. Essa atitude deve originar uma reflexão por parte dos profissionais de saúde, que ainda consideram seu saber como verdade absoluta devendo, portanto, ser obrigatoriamente aplicado.

A visão de educação participativa em saúde, que procura compreender as prioridades da própria comunidade para então, junto com ela, interferir sobre a realidade e desenvolver-se, não se aplica apenas à promoção em saúde, mas a qualquer ação em saúde, incluindo a reabilitação.

$\mathrm{Na}$ área de saúde do trabalhador, nas ações onde o profissional de saúde não é procurado e sim procura sua demanda, essa realidade deve ser ainda mais discutida.

O trabalhador não solicitou uma avaliação audiológica, não está preparado para ouvir o resultado e não acredita que possa se beneficiar de uma reabilitação, na medida em que não se considera um surdo. Sua demanda é sobre o incômodo causado pela exposição ao ruído, e é isso que ele quer ver resolvido. É também comum que ele culpe as pessoas ao seu redor, principalmente a família, acusando-os de falar muito baixo, articularem mal ou excluí-lo deliberadamente da conversa.

Alia-se a isso o fato de que o ruído é um fator de risco presente não só no ambiente de trabalho, mas também em qualquer outro. A exposição ao ruído começa cedo em nossas vidas e é tão comum, que acabamos incorporando sua presença como um estímulo positivo ou como um problema sem solução. Por isso, ele deve ser considerado como um problema de Saúde Pública, ser avaliado em sua real dimensão e ser alvo de estudos que permitam conhecer melhor suas conseqüências. $O$ que se observa, então, é uma sistemática desvalorização da surdez enquanto 
agravo à saúde e sua aceitação como algo natural, inevitável e não muito importante.

Portanto, a ação de reabilitação auditiva é muito mais importante, eficaz e possivel na medida em que possibilita a criação de um espaço de reflexão sobre as questōes relacionadas ao processo saúde-trabalhodoença. O profissional de saúde deve preparar-se para esse tipo de ação, que inclui o processo de reabilitação, mas năo se limita a ele.

Esse modelo parece ser mais adequado ao SUS, uma vez que ao Instituto Nacional de Seguridade Social (INSS), cabe a responsabilidade do pagamento dos benefícios que deveriam garantir ao trabalhador e à sua familia a satisfação das necessidades básicas, durante o período de sua incapacidade para o trabalho (MENDES e DIAS, 1999).

No caso da PAIR, uma vez que só é considerado o resultado do audiograma, independentemente de outras queixas importantes como o zumbido, ou da análise das dificuldades de comunicaçăo, poucos seriam os trabalhadores considerados incapazes para o trabalho. Além de não ser considerada a incapacidade, um afastamento temporário não se justifica, pois não implicará em alteração do quadro clínico do trabalhador. Isso significa que o portador de PAIR tem grande chance de ser demitido e, pouquissima chance de receber uma indenização da seguradora.

Entre as atribuições do INSS estão também os procedimentos de reabilitação profissional, de preparo e/ou treinamento de trabalhadores para permanecerem na sua atividade ou adquirirem uma nova profissão, visando sua reinserção no mercado de trabalho. A reabilitação física, hoje é de responsabilidade do Sistema Único de Saúde (SUS) (Lei n. 8.080/90).

Além de implicar em uma visão mais abrangente, a reabilitação auditiva de trabalhadores portadores de PAIR deve sofrer adequaçōes em relação ao modelo clínico tradicional. Principalmente voltado às crianças, ou aos idosos, a atenção ao portador de deficiência auditiva baseia-se nas etapas de avaliação, aconselhamento, indicação e adaptaçăo de aparelho de amplificação individual e reabilitação terapêutica. Esse tipo de programa 
desenvolveu-se muito nos últimos anos, especialmente em relação ao diagnóstico, devido aos avanços tecnológicos.

Uma das adequações propostas nesse estudo é a aplicação do HHIA. A opção pela aplicação do HHIA, aconteceu na medida em que, apesar não ter sido desenvolvido especificamente para trabalhadores, como o HDHS, 0 conteúdo é semelhante e, o HHIA apresenta maior simplicidade tanto das questões, quanto das alternativas de resposta e forma de avaliação do resultado. Pode-se dizer, entretanto, que ainda devemos pesquisar outras alternativas de instrumentos para a avaliação de dificuldades de comunicação originadas pela PAIR, pois na aplicação do HHIA foi possivel perceber que as dificuldades dos trabalhadores na realização da tarefa de leitura (que implica em decodificação de símbolos e compreensão de seu significado) exigiram muito esforço por parte dos trabalhadores. Essas dificuldades, além de um possível exagero por parte de alguns trabalhadores, poderiam justificar os resultados de percepção de handicap até em quem tem audição normal.

A adoção da teoria das Representações Sociais também pode ser considerada como um avanço metodológico, uma vez que proporciona uma aproximação maior do significado da surdez e de suas relações com o trabalho, por parte do trabalhador. Ela possibilita ao profissional de saúde a realização de ações mais adequadas e qualificadas.

É interessante fazer uma análise do porquê dessas ações não estarem ao alcance do trabalhador, que, por ser exposto ao risco, ou é portador ou é potencial portador de perda auditiva.

Essa questão toma outra dimensão quando lidamos hoje, com uma legislação que pretende incluir os portadores de deficiência no ambiente de trabalho. Mais do que justa, ela ainda precisa de definições e classificações que não permitam sua utilização de forma equivocada. Algumas empresas apresentam os portadores de PAIR como sendo os ocupantes da cota destinada pela legislação. Evidentemente, o portador de PAIR é portador de deficiência e, tornou-se portador de deficiência por trabalhar em ambiente com ruído. Ele já está trabalhando e não era portador de deficiência quando 
foi contratado. A legislação pretende incluir o portador de deficiência no mercado de trabalho e não justificar a deficiência provocada por um ambiente inadequado. De qualquer maneira, essa discussão é pertinente, pois, se agora a empresa admite que o portador de PAIR é um portador de deficiência, devemos então tomar atitudes como: adequação do ambiente de trabalho para esse tipo de deficiência (alarmes visuais, comunicação gestual, análise de protetor auditivo diferenciado, etc.), modificação do ambiente de trabalho que impeça a progressão da deficiência e reconhecimento do INSS desse trabalhador como portador de deficiência, fazendo jus à indenização.

Portanto, devemos sim considerar o trabalhador portador de PAIR como um deficiente auditivo, que deve ser alvo de ações de atenção à saúde, tanto nas empresas como no SUS. 


\section{CONCLUSÕES}

A proposta metodológica de reabilitação auditiva aplicada neste trabalho mostrou-se relevante em vários aspectos, na medida em que cria um espaço de reflexão sobre o processo saúde-trabalho-doença, tão necessário para a mudança das condições de trabalho, além de levar informações aos trabalhadores, que possibilitam, numa ação reflexiva, estabelecer relações entre o ruído e dificuldades de comunicação. Ao mesmo tempo em que aponta a existência de dificuldades reais, indica caminhos possíveis para a superação dessas dificuldades.

Os grupos permitem não só a efetivação de um trabalho educativoterapêutico, com ênfase na participação do trabalhador, mas também o conhecimento da empresa, das relações de trabalho e conseqüentes riscos à saúde, do ponto de vista do trabalhador.

Esse trabalho indicou a limitação da avaliação audiológica na análise das reais dificuldades conseqüentes a PAIR na comunicação, pois $63,7 \%$ da população estudada, referiu percepção de handicap em algum grau, o que sugere a adoção, de rotina, de algum instrumento de avaliação dessa percepção, ou especificamente de dificuldades de comunicação, que permita uma melhor compreensão do quadro clínico.

Para a verificação de correlação entre o grau de perda auditiva e o grau de severidade de dificuldades de comunicação, foi utilizado o HHIA. Observou-se a não existência de correlação entre o grau de perda auditiva e o grau de percepção de handicap, por essa forma de avaliação. No entanto, esse fato se modifica quando analisamos o discurso do trabalhador e suas evocações, o que reforça a necessidade da utilização desses métodos, na avaliação do trabalhador.

As modificações no ambiente de trabalho e processo produtivo que garantam melhores condiçōes de trabalho, apesar das dificuldades de comunicação, foram apontadas pelos próprios trabalhadores e complementadas durante e a realização dos grupos. Basicamente, implica na melhoria da manutenção do ônibus, que provocará a redução da 
exposição ao ruído, e na efetivação de ações junto aos usuários, no sentido de fornecer-lhes as informações necessárias por outros meios, além de fazer perguntas ao motorista. Seria também interessante, promover ações para o conhecimento e para a valorização do motorista de ônibus.

O processo de reabilitação do deficiente auditivo é complexo e deve ser feito, para o trabalhador, como parte integrante de um programa de prevenção e controle. Foi possível, nesse trabalho, realizarmos as primeiras etapas desse processo. Acreditamos que, a partir da sua aplicação rotineira, seja possivel adequá-lo, de forma a desenvolver o processo integralmente, procurando atender suas necessidades individuais.

Para a efetivação deste modelo, é necessário que o processo de vigilância predetermine a realização dos grupos, caso contrário a empresa coloca muitos obstáculos, inclusive ameaçando o trabalhador de demissão, o que provoca a sua não participação.

Os serviços públicos de atenção à Saúde do Trabalhador, em especial os que possuem profissional fonoaudiólogo, devem rever suas açōes, repensando as necessidades da demanda e as possibilidades de intervenção. É fundamental que o profissional de saúde do trabalhador, coordenando um grupo sobre assunto específico, consiga discutir também, mesmo que sem profundidade, qualquer outro aspecto que seja relevante para o trabalhador, como assistência à saúde, legislação trabalhista e previdenciária, sindicato.

Outra questão fundamental refere-se à capacitação do profissional de saúde em educação em saúde. Seus princípios, objetivos e metodologia devem ser compreendidos e vivenciados. Essa prática ainda não foi incorporada pelos profissionais de saúde em geral, o que dificulta uma ação em saúde que considere o sujeito participante e responsável no processo saúde-doença. 


\section{REFERÊNCIAS}

Abric JC. A abordagem estrutural das representaçōes sociais. In: Moreira ASP, Oliveira DC, organizadores. Estudos interdisciplinares de representação social. $2^{a}$ ed. Goiânia: AB; 2000. p.27-46.

Ahumada HT, Ramirez FL. Las condiciones de salud de los conductors de autotransportes urbanos de pasajeros de la ciudad de México. B Sanit Panam 1991; 111 (4): 324-333.

Alpiner J, Chevrette W, Glascoe G, Metz M, Olsen B. The denvel scale of communication function. 1974

Atherly GRC, Noble WG. Clinical picture of occupational hearing loss obtained with the hearing measure scale. In: Robinson DW. Occupational hearing loss. London: Academic Press; 1971.

Axelsson A, Johnson T, Hallberg LRM. Structure of perceived handicap in middle-aged males with noise induced hearing loss, with and without tinnitus. Audiology 1993; 32: p. 137-52.

Bamford J, Saunders E. Hearing impairment, auditory perception and language disability. $2^{\text {nd }}$ ed. San Diego, California: Singular Publishing Group; 1991.

Barbosa ASM. Ruído urbano e perda auditiva: o caso da exposição ocupacional em atividades ligadas à coordenação do tráfego de veículos no município de São Paulo. São Paulo; 2001. [Dissertação de Mestrado - Faculdade de Saúde Pública da USP]. 
Belkic K, Savic C, Thoerell T, Rakic L, Ercegovac D, Djordjevic M. Mechanisms of cardiac risk among professional drivers. Scan J Work Environ Health 1994; 20: 73-86.

Bergman M, Najenson T, Korn C, Harel N, Erental P, Sachartov E. Frequency seletivity as a potencial measure noise damage suscetibility. $\mathrm{Br} \mathrm{J}$ Audiol 1992; 26: 15-22.

Bernardi APA. Trabalhadores expostos simultaneamente a ruído e tolueno: estudo das emissões otoacústicas evocadas transitórias e efeito de supressão. São Paulo; 2000. [Dissertação de mestrado Faculdade de Saúde Pública da USP].

Bess FH, Finlayson PB, Chapman JJ. Pediatrics observation on noise level in infants incubators. Pediatrics 1979; 63 (1)

Blum HL. Planning for health: generics for the eighties. $2^{\text {nd }}$ ed. New York: Human Science Press; 1981.

Bohne BA. Mechanisms of noise damage in the inner ear. In: Henderson D, Hamernick R, Dosanjh DS, Mills JH, editores. Effects of noise on hearing. New York: Raven Press; 1976.

Brasil. Lei 8.080 de 19 de setembro de 1990. Dispōe sobre as condições para promoção, proteção e recuperação da saúde, a organização e o funcionamento dos serviços correspondentes e dá outras providências. Brasília: Assessoria de Comunicação Social do Ministério da Saúde; 1990.

Brasil. Ministério do Trabalho -. Aprova as Normas Regulamentadoras - NR - do Capítulo V, Título II da CLT, relativas à segurança e medicina do trabalho. Portaria n. 3.214, de 8 de junho de 1978 - DOU, 6 jul. 1978. 
Brasil. Ministério do Trabalho - Diretrizes e parâmetros mínimos para avaliação e acompanhamento da audição em trabalhadores expostos a níveis de pressão sonora elevados, da NR7 - Portaria n. 19, Brasília, . DOU, de 9 de abril de 1998.

Britto R. Motorista de ônibus: atuação profissional. In: Anais do $1^{\circ}$ Congresso Nacional de Prevenção de Acidentes de Trabalho; 1975 jan.; Rio de Janeiro, Brasil. Såo Paulo: Artes e Texto; 1975. p. 1076-1109.

Brown ID. Driver fatigue: review of causes of driver fatigue. Human factors $1994 ; 36$ (2): 298-314.

Caiazzo AJ, Tondorf J. Ear canal ressonance and temporary threhsold shift. J Acoust Soc Am 1977; 61: 578.

Campana $\mathrm{Cl}$. Contribuição para o estudo de alguns riscos a que está submetida uma classe de motoristas profissionais. Ribeirão Preto; 1973. [Tese de Doutorado - Faculdade de Farmácia e Odontologia da USP].

Carrère S, Evans GW, Palsane MN, Rivas $M$. Job strain and occupational stress among urban publica transit operators. J Occup Psychol 1991; 64: 305-316.

Celani AC. Brinquedos e seus niveis de ruido. Rev Dist Com 1991; 4 (1): 49-58.

Celani AC, Bevilácqua MC, Ramos CR. Ruido em escolas. Fono: Rev Atual Cient 1994; 6 (2): $1-4$.

Chadwik D. Noise and the ear. In: Balatyne J, \& Groves J, editores. ScottBrown 's Diseases of the Ear, Noise and Throath. $3 t^{\text {h }}$ ed; London, Butterworth, 1971. p.475-539. 
Comitê Nacional de Ruído e Conservação Auditiva. Perda auditiva induzida pelo ruído relacionada ao trabalho. Boletim, São Paulo, n. 1 de 29.6.1994, revisto em 14.11.1999.

Cordeiro R, Lima Filho EC, Nascimento LCR. Associação da perda auditiva induzida por ruido com o tempo acumulado de trabalho entre motoristas e cobradores. Cad Saúde Públ 1994; 10 (2): 210-221.

Costa EA. Audiometria tonal e testes de reconhecimento da fala: estudo comparativo para aplicação em audiologia ocupacional. ACTA AWHO, 1992; 11 (3): 137-42.

Davis $H$, Silverman SR. Hearing and deafness. $4^{\text {th }}$ ed. New York: Holt, Rinehart and Winston; 1960.

Demorest ME, Erdman SA. Scale composition and item analysis of the communication profile for the hearing impaired. J Acad Rehab Audiol 1986; 29: 515-535.

Duffy CA, McGodrik AE. Stress and the bus driver in the UK transport industry. Work and Stress 1990; 4 (1): 17-27.

Dunn DE. Cochlear morphology associated with overexposure to noise hearsay. J Ohio Speech Hear Assoc 1987: 22-28.

Evans GW, Carrère S. Traffic congestion, perceived control, and psychophysiological stress among bus drivers. J Appl Psych 1991; 76 (5): 658-663.

Evans GW. Working on the hot seat: Urban bus operators. Accid Anal Prev $1994 ; 26(2): 181-193$. 
Feldman AS, Grimes CT. Hearing conservation in industry. Baltimore, The Williams \& Wilkins, 1985.

Ferreira $A B H$. Dicionário Aurélio básico da língua portuguesa. Rio de Janeiro: Nova Fronteira; 1988.

Ferreira Jr M. PAIR - Perda Auditiva Induzida por Ruído: bom senso e consenso. São Paulo: VK; 1998.

Fiorini AC, Fischer FM. Emissőes otoacústicas por transiente evocado em trabalhadores expostos a ruído ocupacional. Rev Dist da Com 2000;11 (2): 167-191.

Fiorini AC, Nascimento PES. Programa de prevenção de perdas auditivas. In: Nudelmann AA, Costa EA, Seligman J, Ibañez RN (org). PAIR - Perda Auditiva Induzida pelo Ruído. Rio de Janeiro: Revinter; 2001. v. 2, p. 51 61.

Fonseca JC. Avaliação da exposição ao ruído dos motoristas e cobradores de ônibus urbano de São Paulo. São Paulo: Fundacentro; 1993.

França D. O ruído presente nas salas de aula em Curitiba: um assunto a ser refletido pelos fonoaudiólogos. Rev Soc Bras Fono 2000 jun.; 4 (6):65-67.

Frazza MM, Caovilla HH, Munhoz MSL, Sila MLG, Ganança MM. Audiometria tonal e vocal. In: Munhoz MSL, Caovilla HH, Silva MLG, Ganança MM. Audiologia Clínica. São Paulo: Atheneu; 2000. p. 49-72.

Getty L, Hétu R. Development of a rehabilitation program for people affect with occupational hearing loss. Audiology 1991; 30: 317-329. 
Giampaoli E, Saad IFSD, Cunha IA. Avaliação da exposição ocupacional ao ruído. Norma de higiene ocupacional: procedimento técnico. São Paulo: Fundacentro; 1999.

Gil-Carcedo y Garcia LM. Problemática atual do ruído na indústria. Controle da audição. Rev Bras Saúde Ocup 1980; 8 (30): 55-58.

Giolas TG, Owens E, Lamb SH, Schubert ED. Hearing performance inventory. J Speech Hear Disord 1979; 44: 169-195.

Giolas TG. Reabilitação aural de adultos com deficiência auditiva. In: Katz J. Tratado de audiologia clínica. $4^{a}$ ed. São Paulo: Manole; 1999. p. 766-782.

Golstein DP, Stephens SDG. Audiological rehabilitation: management model I. Audiology 1981; 20: 432-452.

Gustavsson PL, Alfredsson H, Brunnberg N, Hammar R, Jakobsson C, Reuterwall P. Myocardial infarction among male bus, taxi, and lorry drivers in Middle Sweden. Occup Environ Med 1996; 53(4): 235-240.

Hartikainen AL, Sorri M, Anttonen H, Tuimala R, et al. Effect of occupational noise on the course and outcome of pregnancy. Scand $J$ Work Environ Health 1994 Dec.; 20 (6): 444-50.

Hétu R, Getty L, Tran Quoc H. Impact of occupational hearing loss on the lives of workers. In: Morata TC, Dunn DE. Occupational medicine: state of the art reviews. Philadelphia: Hanley \& Belfus; 1995 . v. 10, n. 3. p. 495512. 
Hètu R, Lalande M, Getty L. Psychosocial disadvanteges associated with occupational hearing loss as experienced in the family. Audiology $1987 ; 26$ : 141-152.

Hètu R, Tran Quoc H. Psychoacoustic Performance in Workers with NIHL. In: Axelsson A, Borchgrevink HM, Hamernick RP, Hellstrom P, Henderson D, Salvi RJ. Scientific bases of noise-induced hearing loss. New York: Thieme Medical Publishers; 1996. p. 264-285.

Hetu R. Mismatches between auditory demands and capacities in the industrial work environment. Audiology 1994; 33: 1-14.

High WS, Fairbanks G, Glorig A. Scale for self-assessment of hearing handicap. J Speech Hear Disord 1964; 29: 215-230.

Hilding AC. Studies on otic labyrinth: anatomic explanation for hearing dip at 4.096 Hz characteristic of acoustic trauma and presbycusis. Ann Oto Rhinol Laryngol 1953; 62: 950-956.

Hodgson WR. O aconselhamento e a orientação da prótese auditiva. In: Katz J. Tratado de audiologia clínica. São Paulo: Manole; 1989. p. 963-973.

Hungria H. Otorrinolaringologia. Rio de Janeiro: Guanabara-Koogan; 1995.

Hutton CL. Responses to a hearing problem inventory. J. Acad. Rehab. Audiol. 1980;13:133-154.

Kaplan H, Feeley J, Brown J. A modified Denver scale: test-retest reliability. J Acad Ehab Audiol 1978; 11: 15-32.

Klemenc $M$. A centralidade dos sons na produção do sentido: contribuição para uma política de prevenção da perda auditiva no 
trabalho com ruído. São Paulo, 1998. [Dissertação de Mestrado. Faculdade de Saúde Pública da USP].

Kompier M, Mulders $H$, Meijman T, Boersma M, Groen G, Bullinga R. Absence behavior, turnover and disability: a study among city bus drivers in the Netherlands. Work and Stress 1990; 4 (1): 83-89.

Kompier M. Bus drivers: occupational stress prevention. Genêve: International Labour Office; 1996. (ILO Publications, v. 39).

Kühlman TM. Coping with occupational stress among urban bus and tram drivers. J Occup Psycho 1990; 63: 89-96.

Kryter KD. The effects of noise on man. New York, Academic Press, 1985.

Lalande, NM, Hètu R, Lambert $\mathrm{J}$. Is occupational noise exposure during pregnancy a risk factor of damage to the auditory system of the fetus? American Journal of Industrial Medicine, Quebec, Canadá: Universitè de Montréal; 1986.

Levitt $H$. Speech discrimination ability in the hearing impaired: spectrum considerations. In: Studebaker GA, Bess FH, editors. The Vanderbilt hearing report: monographs in contemporary audiology. Upper Darby, PA: 1982.

Lim AJ, Dunn DE. Anatomic correlates of noise induced hearing loss. Otol Clinn North Am 1979; 12 (3): 493-513.

Ling D, Ling AH. Aural habilitation. Washington DC: Alexander Graham Bell Association for the Deaf; 1978. 
Lopes MBPO. Pequena história dos transportes públicos. São Paulo: Companhia Municipal dos Transportes Coletivos; 1985.

Lutman ME, Brown EJ, Coles RRA. Self reported disability and handicap in the population in relation to pure tone threshold, age, sex and type of hearing loss. Br J Audiol 1987; 21: 45-58.

Macrae JH. Tinnitus and percentage loss of hearing. Aust J Audiol 1992; 14: 19-23.

Magni C. As incapacidades auditivas e o handicap de trabalhadores portadores de PAIR e de suas esposas. São Paulo; 1997. [Dissertação de Mestrado - Distúrbios da Comunicação - Pontifícia Universidade Católica de São Paulo].

Marques SR. Os efeitos do ruído em motorista de ônibus urbano no município de São Paulo. São Paulo, 1998.[Dissertação de Mestrado Faculdade de Fonoaudiologia da PUC - SP].

McLauchlin RM. Hearing orientation for adults clients. In: Hull RH. Aural Rehabilitation. $2^{\mathrm{a}}$ ed. San Diego: Singular Publishing Group; 1992. p. 149159.

McShane DP, Hyde ML, Alberti PW. Tinnitus prevalence in industrial hearing loss compensation claimants. Clin Otol 1988; 13: 323-330.

Melnick W. Saúde auditiva do trabalhador. In: Katz J. Tratado de audiologia clínica. $4^{\mathrm{a}}$ ed. São Paulo: Manole; 1999. p. 529-547.

Mendes R, Dias EC. Saúde dos trabalhadores. In: Rouquayrol Z, Almeida Filho N. Epidemiologia \& saúde. Rio de Janeiro: Medsi; 1999. p. 431-456. 
Mendes D, Vianna RD. Educação em Saúde - Tendência atual. In: Manno Vieira R,Manno Vieira M, Ávila CRB, Pereira LD (org). Fonoaudiologia e Saúde Pública. Carapicuíba, Pró-fono, 2000,

Merluzzi F. Patologia da rumore. In: Sartorelli E. Trattato di medicina del lavoro. Pádua, Piccin Editore;1981. v. 2; p. 1.119-1.149.

Morata TC, Lemasters GK. Consideraçōes epidemiológicas para o estudo de perdas auditivas ocupacionais. In: Nudelmann AA, Costa EA, Seligman J, Ibañez RN (org). PAIR - Perda Auditiva Induzida pelo Ruído. Rio de Janeiro: Revinter; 2001. v. 2;p.1-16.

Munhoz MSL, Silva MLG, Frazza MM, Caovilla HH, Ganança MM, Carvalho P. Otoemissões acústicas. In: Munhoz MSL, Caovilla HH, Silva MLG, Ganança MM. Audiologia clínica. São Paulo: Atheneu; 2000a. p. 121-148.

Munhoz MSL, Silva MLG, Caovilla HH, Frazza MM, Ganança MM, Câmera JLS. Respostas auditivas de tronco encefálico. In: Munhoz MSL, Caovilla HH, Silva MLG, Ganança MM. Audiologia Clínica. São Paulo: Atheneu; 2000 b. p. $191-220$.

Netterstrom B. Cancer incidence among urban bus drivers in Denmark. Int Arch Occup Environ Health 1988; 61:217-221.

Newman CW, Weinstein BE, Jakcobson GP, Hug GA. The Hearing Handicap Inventory for Adults: psychometric adequacy and audiometric correlates. Ear Hear 1990; 11 (6): 430-33.

Noble WG, Atherly G. The hearing measurement scale: a questionnaire for the assessment of auditory disability. J Speech Hear Res 1970; 23: 470479. 
Nurminen T, Kurppa $\mathrm{K}$.ccupational noise exposure and course of pregnancy. Scand J Environ Health 1989; Apr.; 15 (2): 117-24.

Nurminen T. Female noise exposure, shift work, and reproduction. J Occup Environ Med 1995 Aug.;37 (8): 945-50.

Oliveira JAA. Fisiología clínica da audição - cóclea ativa. In: Nudelmann AA, Costa EA, Seligman J, Ibañez RN. PAIR: Perda Auditiva Induzida por Ruído. Porto Alegra, Bagaggem Comunicação, 1997.

Pereira MG. Epidemiologia: teoria e prática. Rio de Janeiro: GuanabaraKoogan; 1995.

Picaluga IF. Riscos e danos: um estudo de saúde ocupacional. Anais.do VII Encontro Anual da ANPPOCS; 1983; Săo Paulo, Brasil.

Pinho C, Figueiredo MJO, Ebert MF, Bittencourt LAK. Alterações cardiovasculares em motoristas de ônibus. Rev Bras Saúde Ocup 1991; 72 (10): 53-58.

Pozzi MPS. Pesquisa participante: o trabalhador enquanto sujeito e objeto de análise das condições de trabalho na Jurema ll - empresa de transporte coletivo. São Paulo: Prefeitura do Município de Săo Paulo. Secretaria Municipal da Saúde. Centro de Referência em Saúde do Trabalhador da Santo Amaro; 1993.

Ragland DR, Winkleby MA, Schwalbe J, Holman BL, Morse L, Syme SL, Fisher JM. Prevalence of hypertension in bus drivers. Int J Epid 1987; 16(2): 208-14. 
Rigotto RM. Investigando a relação entre saúde e trabalho. In: Buschinelli JTP, Rocha LE, Rigotto RM, organizadores. Isto é trabalho de gente? Vida, doença e trabalho no Brasil. Petrópolis: Vozes;1994.p 159-177.

Robinson DW, Wilkins PA, Thyer NJ, Lawes JF. Auditory impairment and onset of disability and handicap in noise induced hearing loss. ISVR Techn Report. 1984; 126.

Rosengreen A, Anderson K, Wilhelmsen L. Risk of coronary heart disease in middle-aged male bus and tram drivers compared to men in other occupations: a prospective study. Int J Epidem 1991; 20 (1): 82-87.

Ross M. Reabilitação aural: uma visão geral. In: Katz J. Tratado de audiologia alínica. $4^{a}$ ed. São Paulo: Manole; 1999. p. 581-589.

Russo ICP. Acústica e psicoacústica aplicadas à fonoaudiologia. São Paulo: LOVISE; 1993.

Sá CP. A construção do objeto de pesquisa em representações sociais. Rio de Janeiro: Editora da UERJ; 1998.

Santos Jr EA, Mendes R. Estudo das condiçōes de trabalho e saúde de motoristas de ônibus urbano de Belo Horizonte - MG. Rev Bras de Saúde Ocup 1995/1996; 25: 131-142.

Santos UP, Matos MP. Aspectos de física. In: Santos UP, Organizador Ruído: riscos e prevenção. São Paulo: Hucitec; 1994. p. 7-23.

Santos UP, Morata TC. Efeitos do ruido na audição. In: Santos UP, organizador. Ruído: riscos e prevenção. São Paulo: Hucitec; 1994. p. 4354. 
Sato L. A representação social do trabalho penoso. In: Spink MJ, organizador. O conhecimento do cotidiano: as representações sociais na perspectiva da psicologia social. São Paulo: Brasiliense; 1995. p. 188211.

Schow RL, Nerbonne Ma. Assessment of hearing handicap by nursing home residents and staff. J Acad Rehab Audiol 1977; 10:2-12.

Sistema Estadual de Análises de Dados Estatísticos (Seade)/Fundação Jorge Duprat Figueiredo de Segurança e Medicina do Trabalho (Fundacentro). Pesquisa de condições de saúde e segurança dos motoristas. São Paulo; 2000.

Selye H. A syndrome produced by diverse nocuous agents. Nature $1936 ; 32$ : 138.

Seshagiri B. Occupational noise exposure of operators of heavy trucks. Am Ind Hyg Assoc J 1998; 59: 205-213.

Silva LF. Curso básico sobre avaliação de ruído em ambientes de trabalho. São Paulo: 1993. [Apostila do Projeto de Cooperação Técnica Brasil/Itália - Centro de Vigilância Sanitária da SES/SP].

Silva LF. Estudo sobre a exposição combinada entre ruido e vibração de corpo inteiro $\theta$ os efeitos na audição de trabalhadores. São Paulo; 2002. [Tese de Doutorado - Faculdade de Saúde Pública da USP].

Silva RCM. Perda auditiva induzida pelo ruido: instrumentos de autoavaliação dos efeitos auditivos e psicossociais. São Paulo; 1997. [Dissertação de mestrado - Pontifícia Universidade Católica de São Paulo]. 
Soll-Johanning $\mathrm{H}$, Bach $E$, Olsen $H$, Tüchsen F. Cancer incidence in urban bus drivers and tramway employees: a retrospective cohort study. Occup Environ Med 1998; 55: 594-98.

Souza MFM, Silva GR. Risco de distúrbios psiquiátricos menores em área metropolitana na região Sudeste do Brasil. Rev Saúde Públ 1998; 32 (1): 50-8.

Souza MFM, Uehara M, Bussacos MA, Freire NB, Matsuoa M, Santos TLF, Loeff EW, Hernandes R. Estudos das condições de saúde e trabalho dos motoristas e cobradores urbanos da cidade de São Paulo. São Paulo: Faculdade de Medicina da USP. Departamento de Medicina Preventiva; 1991.

Stephens, SDG. Audiological rehabilitation. In: Kerr, AG. Scott-Brown's otolaryngology. $5^{a}$ ed. London: Butterrworth International; 1987 . v. 2; p. 446-480.

Stillman e Dawn. Trabalho e saúde na indústria. São Paulo: EDUSP; 1975.

Sulkolswky WJ. Industrial noise pollution and hearing impairment. Springfield: US Departament of Commerce. National Technical Information Service; 1980.

Thompson ME. Aging, hearing loss and hearing aids: myths revisited. Am Rehab 1993/1994; 19: 5-20.

Van Tasell DJ. Auditory perception of the speech. In: Davis JM, Hardick EJ, editores. Rehabilitative audiology for children and adults. New York: Johm Wiley \& Sons; 1981. 
Ventry IM, Weinstein BE. The hearing handicap inventory for the elderly: a new tool. Ear end Hear 1982; 83: 128-234.

Vesterager V. Tinnitus: investigation and management. BJM 1997; 314: 728731.

Weinstein B. A review of Hearing Handicap Scale. Audiology, v. 9,1984: 91109.

Weinstein B. Presbiacusia. In: Katz J. Tratado de audiologia clínica. $4^{a}$ ed. São Paulo: Manole; 1999. p. 562-577.

WHO. International classification of impaiments, disabilities and handicaps: a manual of classifications relating to consequences of disease. Geneva; 1980: 25-43.

Wieselberg MB. A auto-avaliação do handicap em idosos portadores de deficiência auditiva: o uso do HHIE. São Paulo; 1997. [Dissertação de mestrado - Pontifícia Universidade Católica de São Paulo].

Wilson RH, Strouse AL. Audiometria com estímulos de fala. In: Musiek FE, Rintelmann WF. Perspectivas atuais em avaliação auditiva. São Paulo: Manole; 2001. p.21-62.

Zuskin E, Mustajbegovic J, Schachter EN. Respiratory symptoms and lung function in bus drivers and mechanics. Am J Ind Med 1994; 26(6): 771-783. 
ANEXOS 
ANEXO 1 


\section{FICHA AUDIOLÓGICA CEREST/SP}

DATA: $1 \quad 12001$

NOME:

REGISTRO:

IDADE: anos

SEXO: 1. masculino

2. feminino

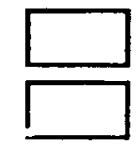

ENCAMINHADO POR

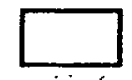

TIPO DE CONSULTA

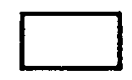

SITUAÇÃO OCUPACIONAL

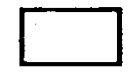

SITUAÇÃO PREVIDENCIÁRIÄ

1. IMPRESSÃO SOBRE A PRÓPRIA AUDIÇÃO:

Direito

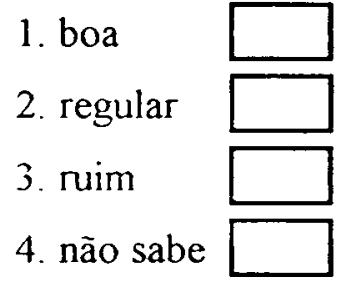

Esquerdo

1. boa

2. regular

3. ruim

4. não sabe

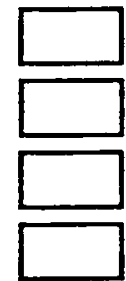

Tempo: meses (somente para as alternativas "regular" e "ruim"; considerar o pior ouvido)

2. ANTECEDENTES PESSOAIS

2.1 INFECÇÃO OU DOR NA ORELHA:

1. $\operatorname{sim}$

2. não

3. não sabe

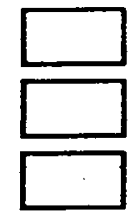

2.2 SE SIM, QUAL A FREQUÊNCIA DESSES EPISÓDIOS? 


\begin{tabular}{|c|c|c|c|c|}
\hline \multirow[t]{7}{*}{2.3 DOENÇAS } & sarampo & 1. $\operatorname{sim}$ & 2. não & 4. não sabe \\
\hline & caxumba & 1. $\operatorname{sim}$ & 2. não & 4. não sabe \\
\hline & meningite & 1. $\operatorname{sim}$ & 2. não & 4. กฉ̃o sabe \\
\hline & pressão alta & 1. sim & 2. não & 4. não sabe \\
\hline & diabetes & 1. $\operatorname{sim}$ & 2. não & 4. não sabe \\
\hline & prob cardiovasc. & 1. sim & 2. não & 4. não sabe \\
\hline & outros & 1. $\operatorname{sim}$ & 2. não & 4. não sabe \\
\hline
\end{tabular}

OBS:

2.4 CIRURGIA DE ORELHA 1. não

2. sim, bilateral

3. sim, $\mathrm{OD}$

4. sim, $\mathrm{OE}$

5, sim, não sabe referir o lado

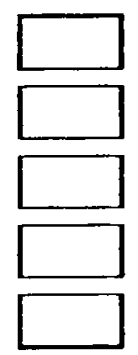

Tempo: meses

OBS:

3. TRAUMA CRANIANO 1. sim

2. กล̃o

4. não sabe

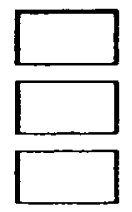

Tempo: meses

OBS:

4 TRAUMA ACÚSTICO 1. sim

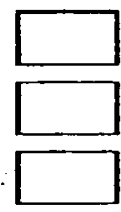

Tempo meses

OBS 
5 ANTECEDENTES AUDIOLÓGICOS FAMILIARES SIGNIFICATIVOS 1. sim

2. ทั̃a

4. não sabe;

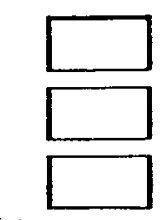

Tempo: meses

OBS:

6 ZUMBIDO

1. $\operatorname{sim}$

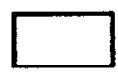

2. não

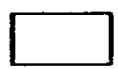

6.1 LOCALIZAÇÃO 1. OD

2. $\mathrm{OE}$

3. bilateral

4. não sabe

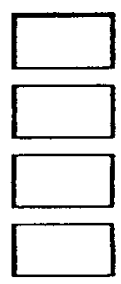

\section{DADOS OCUPACIONAIS}

7.1 Exposição anterior a ruído

$\begin{array}{lll}\text { ramo: } & \text { função: } & \text { tempo: } \\ \text { ramo: } & \text { função: } & \text { tempo: } \\ \text { ramo: } & \text { função: } & \text { tempo: } \\ \text { ramo: } & \text { função: } & \text { tempo: }\end{array}$

OBS:

7.2 Empresa onde trabalha:

7.3 Ramo de atividade:

7.4 Setor:

7.5 Função:

7.6 Horas diária de trabalho:

7.7 Tempo de trabalho na empresa:

7.8 Exposição a ruido ocupacional:

Tempo na empresa: meses

Tempo total meses 
i.

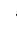

7.10. Impressão sobre o ruido 1. baixo

2. médio

3. alto

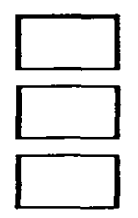

7.11. Outros sintomas auditivos não sim, peida teinporária da audição sim, zumbido sim, ambos sim, outros

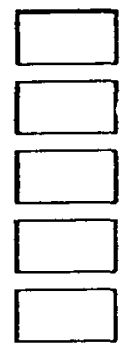

7.12. Uso de EPI

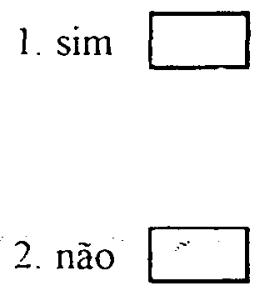

\section{1 concha \\ 1.2 plug \\ 1.3 outros}

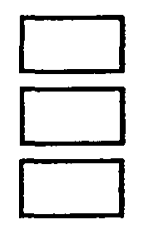

Tempo: meses

OBS:

8. EXPOSIÇÃO A RLIDO EXITRA-LABORAL 1. sim 2. não

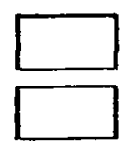

Tempo: meses

OBS:

\section{EXAMES AUDIOMÉTRICOS ANTERIORES 1. sim} 2. não

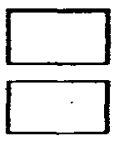

9.1. Se sim:

$\begin{array}{lr}\text { Local: } & \text { Dat } \\ \text { Local: } & \text { Dat } \\ \text { Local: } & \text { Dat }\end{array}$
Resultado Resultado Resultado: 
10. No trabalho, você tem contato com substâncias químicas?

( ) não ( ) sim

Quais?

11. Freqüência que sente o zumbido?

( ) diariamente

( ) semanalmente

( ) quinzenalmente

( ) mensalmente

( ) esporadicamente

( ) não sabe

Há quanto tempo?

$\begin{array}{llllllll}0 & 1 & 2 & 3 & 4 & 5 & 6 & 7\end{array}$

12. Como é o zumbido?
( ) grave
( ) agudo
( ) não sabe

13. Com o que se parece?
( ) abelha
( ) grilo
( ) campainha
( ) chuva
( ) TV fora do ar
( ) não sabe
( ) alto
( ) médio
( ) baixo
( ) não sabe

14. O zumbido é sempre igual?
( ) $\operatorname{sim}$
( ) nào sabe
( ) não

15. Em que período do dia é mais intenso o zumbido?
( ) dia inteiro
( ) manhà
( ) tarde
( ) noite
( ) mais de um período
( )
( ) não sabe

\begin{tabular}{ll} 
( ) assobio \\
() pulsação \\
() avião \\
( ) apito \\
\hline
\end{tabular}

Obs: 
ANEXO 2 
CERESTISP

Rua Conselhelro Crisplniano, 20 - $8^{\circ}$ and Cep: 01037-000 Sæao Paulo - Fone: 231-6390

Nome: RG FICHA AUDIOLÓGICA

Sexo: ( ) M( )F Idade:

Enpresa:

Tempo na empresa:

Registro:

Tempo total de exposição:

Funçio:

Andionnaro:

Africto Acistion:

Impcedanciomudro:

Cabine: ( ) sim ( ) năo Repouso Acistico: ( ) sim ( ) nส̄o

-

ORELHA DIREITA

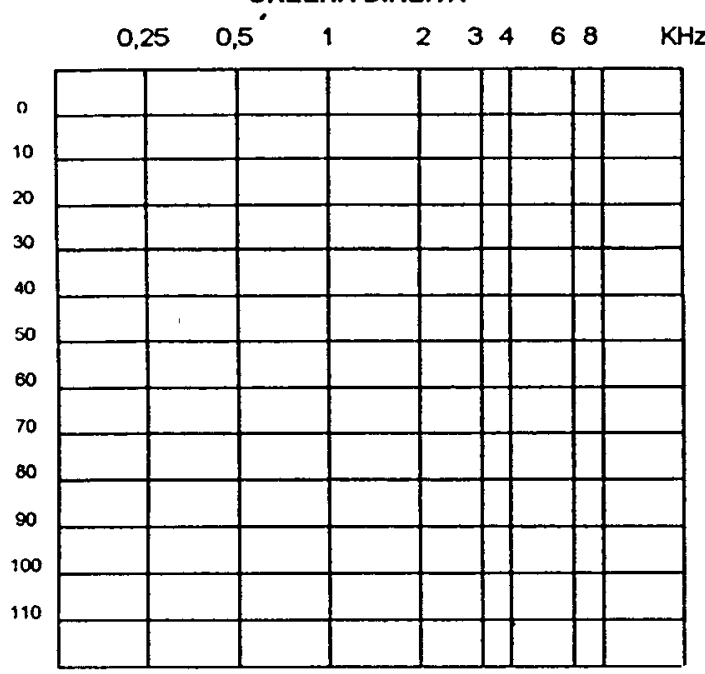

dB

TIMPANOMETRIA
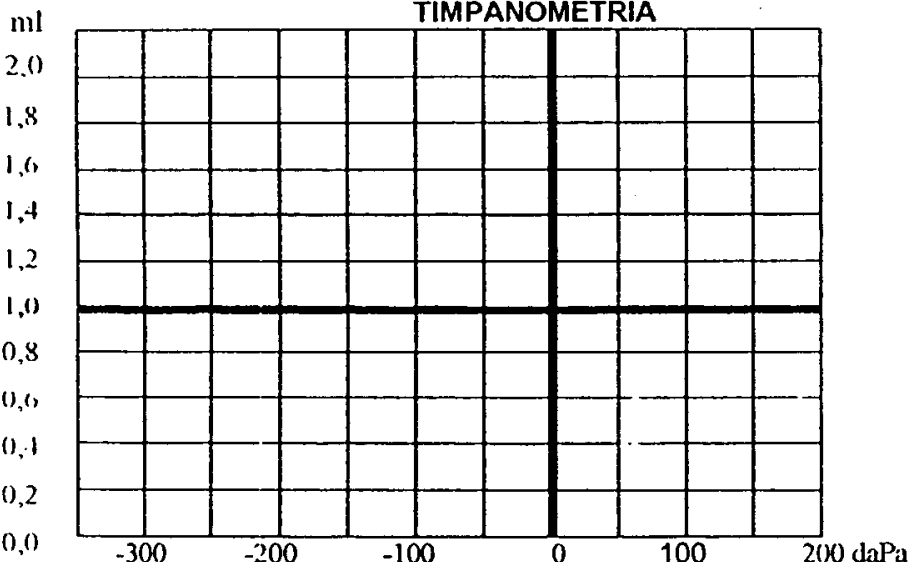

\section{ORELHA ESQUERDA}

Muscuromento

())

VA

VO:

OE

VA:

VO:

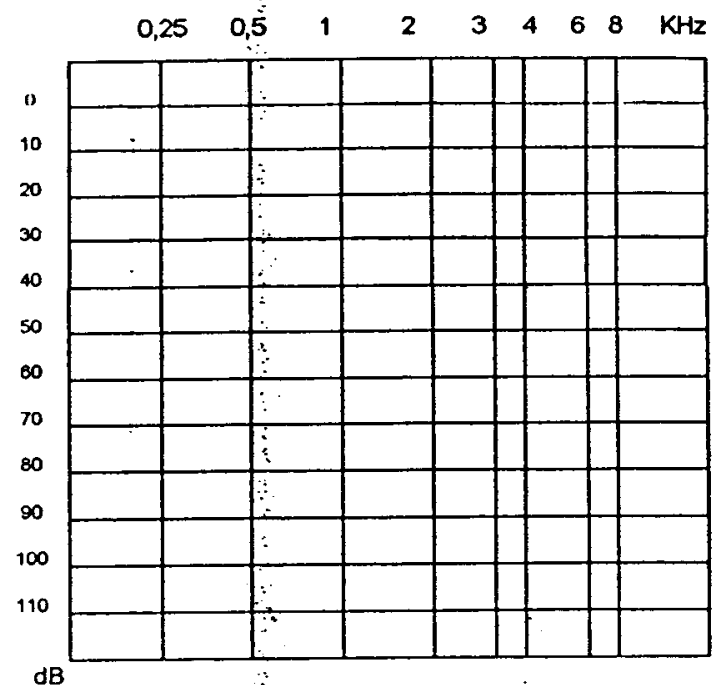

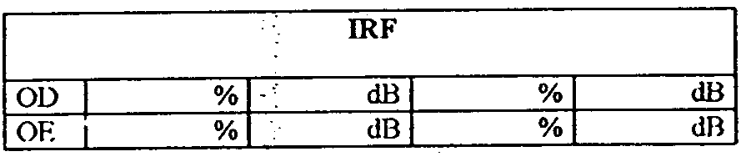

\begin{tabular}{|l|l|}
\hline \multicolumn{2}{|c|}{ SRT } \\
\hline $\mathrm{OD}$ & $\mathrm{dB}$ \\
\hline $\mathrm{OE}$ & $\mathrm{dB}$ \\
\hline
\end{tabular}

\begin{tabular}{|c|c|c|c|c|c|}
\hline \multicolumn{6}{|c|}{ WEBER } \\
\hline & $500 \mathrm{hZ}$ & $1 . \mathrm{khZ}$ & $2 \mathrm{khZ}$ & $4 \mathrm{khZ}$ & \\
\hline OD & & $\vdots$ & & & OE \\
\hline
\end{tabular}

\begin{tabular}{|l|l|l|}
\hline COMPLIÁNCTA & OD & OE \\
\hline Press3o (daPa) & & \\
\hline Posiço Neutra (ml) & & \\
\hline r200 daPa (ml) & & \\
\hline Compliancia (ml) & & \\
\hline
\end{tabular}

\begin{tabular}{|c|c|c|c|c|c|c|c|c|}
\hline \multicolumn{9}{|c|}{ REFLEXO ACÚSTICO DO MÚSCULO ESTAPÉDIO (dB) } \\
\hline FPEQ. Hz & $\begin{array}{c}\text { Limiar } \\
\text { O.D. }\end{array}$ & $\begin{array}{l}\text { AF. D. } \\
\text { contra }\end{array}$ & Difer. & $\begin{array}{c}\text { AF. D: } \\
\text { ipsi }\end{array}$ & $\begin{array}{c}\text { Limiar } \\
\text { O.E. }\end{array}$ & $\begin{array}{l}\text { AF. E. } \\
\text { contra }\end{array}$ & Difer. & $\begin{array}{c}\text { AF. E. } \\
\text { ipsi }\end{array}$ \\
\hline 500 & & & & $\therefore$ & & & & \\
\hline IK & & & & : & & & & \\
\hline $2 \mathrm{~K}$ & & & & $\therefore$ & & & & \\
\hline $4 K$ & & & & 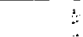 & & - & & \\
\hline
\end{tabular}

OHSERVAÇOES 
ANEXO 3 
Questionário de auto-avaliação de percepção de handicap (VENTRY e WEINSTEIN, 1982, modificado por NEWMAN, 1990)

O objetivo deste questionário é identificar os problemas que sua perda auditiva pode estar lhe causando. Responda SIM, ALGUMAS VEZES ou NĀO, para cada questão. Não pule uma questão se vocé evita a situação em função do seu problema auditivo. Se você usa aparelho de amplificação, por favor, responda da maneira como ouve sem aparelho.

1. Seu problema auditivo faz com que você use menos o telefone do que gostaria?

SIM（） NÄO( ) ALGUMAS VEZES ( )

2. Seu problema auditivo faz com que você se sinta sem graça quando é apresentado a alguém?
$\operatorname{SIM}()$
$\mathrm{NĀO}()$
ALGUMAS VEZES（）

3. Seu problema auditivo faz com que você evite grupos de pessoas?

SIM( ) NÄO( ) ALGUMAS VEZES ( )

4. Seu problema auditivo torna-o irritado?
$\operatorname{SIM}()$
$N A \vec{O}($ )
ALGUMAS VEZES（）

5. Seu problema auditivo o faz sentir-se frustrado quando conversa com membros de sua família?
$\operatorname{SIM}()$
$\mathrm{NĀO}($ )
ALGUMAS VEZES ( )

6. Seu problema auditivo causa-lhe dificuldades em festa?
$\operatorname{SIM}()$
$\mathrm{NĀO}($ )
ALGUMAS VEZES（ )

7. Seu problema auditivo o faz sentir-se frustrado ao conversar com os colegas de trabalho?

SIM ( ) NÃO( ) ALGUMAS VEZES ( )

8. Você sente dificuldade em ouvir quando alguém fala sussurrado?
$\operatorname{SIM}()$
NÃO( )
ALGUMAS VEZES（）

9. Você se senta prejudicado em função do seu problema auditivo?

SIM( ) NÃO( ) ALGUMAS VEZES ( )

10. Seu problema auditivo lhe traz dificuldades quando visita amigos, parentes ou vizinhos?

SIM( ) NÃO( ) ALGUMAS VEZES( ) 
11. Seu problema auditivo faz com que você tenha problemas para ouvir ou entender os colegas de trabalho?

$\operatorname{SIM}()$

NÃO( )

ALGUMAS VEZES（）

12. Seu problema auditivo o torna nervoso?

$\operatorname{SIM}()$

$\mathrm{NÃO}($ )

ALGUMAS VEZES ( )

13. Seu problema auditivo faz com que você visite amigos, parentes ou vizinhos menos do que gostaria?

$\operatorname{SIM}()$

$\mathrm{NÃO}($ )

ALGUMAS VEZES ( )

14. Seu problema auditivo desencadeia brigas com os membros da família?

SIM ( ) $\mathrm{NÃO}($ )

ALGUMAS VEZES ( )

15. Seu problema auditivo leva-o a sentir dificuldades em ouvir rádio ou TV?

$\operatorname{SIM}()$

$\mathrm{NÄO}($ )

ALGUMAS VEZES ( )

16. Seu problema auditivo faz com que você vá menos às compras do que gostaria? $\operatorname{SIM}()$ $\mathrm{NÃO}($ )

ALGUMAS VEZES ( )

17. Algum problema ou dificuldade com sua audição definitivamente o aborrece?

SIM( ) NÃO( ) ALGUMAS VEZES ( )

18. Seu problema auditivo faz com que você queira star sozinho, agir por conta própria?

$\operatorname{SIM}() \quad N A ̃ O()$

ALGUMAS VEZES ( )

19. Seu problema auditivo faz com que você converse com os familiares menos do que gostaria?

SIM( ) NÄO( )

ALGUMAS VEZES（）

20. Você sente que qualquer dificuldade com sua audição limita sua vida pessoal ou social?

SIM( ) NÃO( )

ALGUMAS VEZES（）

21. Seu problema auditivo the causa dificuldades com parentes ou amigos em restaurantes?

SIM( ) NÃO( ) ALGUMAS VEZES ( )

22. Seu problema auditivo faz com que vocé fique deprimido?

$\operatorname{SIM}()$

NÃO( )

ALGUMAS VEZES ( )

23. Seu problema auditivo faz com que você ouça TV e rádio menos do que gostaria?

$\operatorname{SIM}()$

$\mathrm{NÃO}($ )

ALGUMAS VEZES ( ) 
24. Seu problema auditivo faz com que você se sinta incomodado quando conversa com amigos?

SIM( ) NÃO( ) ALGUMAS VEZES ( )

25. Seu problema auditivo faz com que você se sinta deixado de lado quando em um grupo de pessoas?

SIM( )

$\mathrm{NĀO}(）$

ALGUMAS VEZES（） 
ANEXO 4 

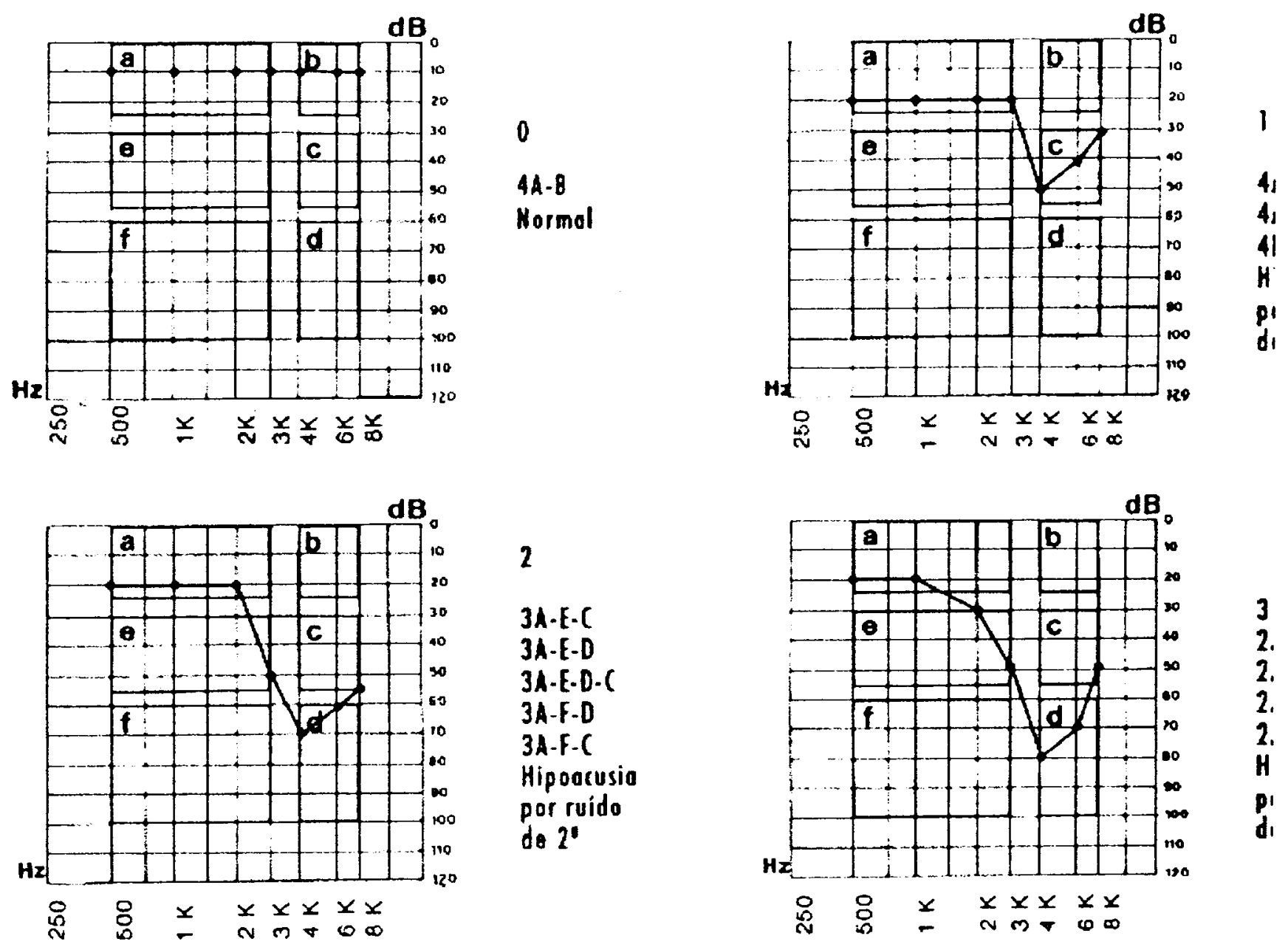

$44-8$
Normal
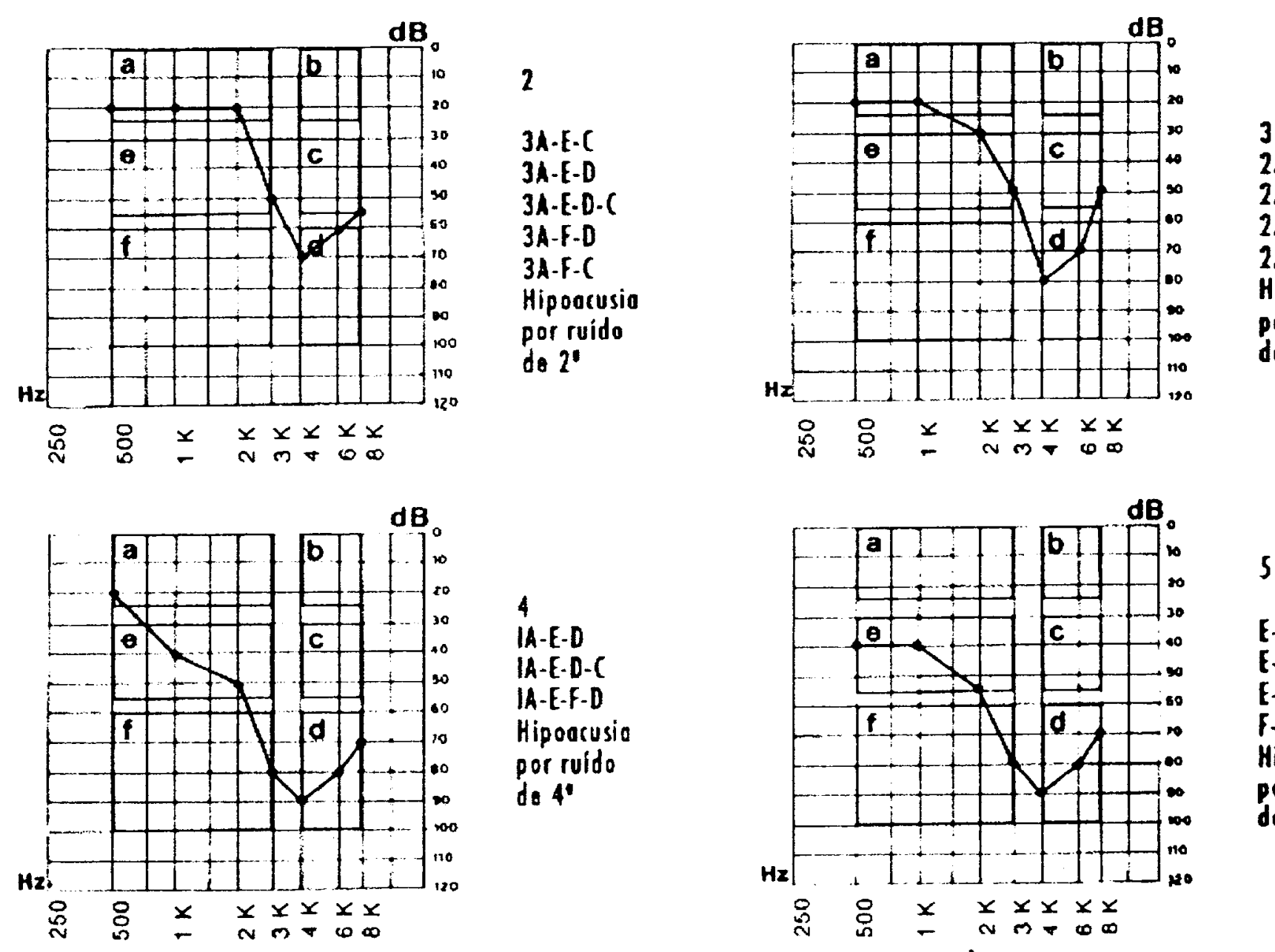

3A.E.C

3A-E-D

3A-E.D.C

3A-F-D

3A-F-C

Hipoocusio

por ruido

de 2
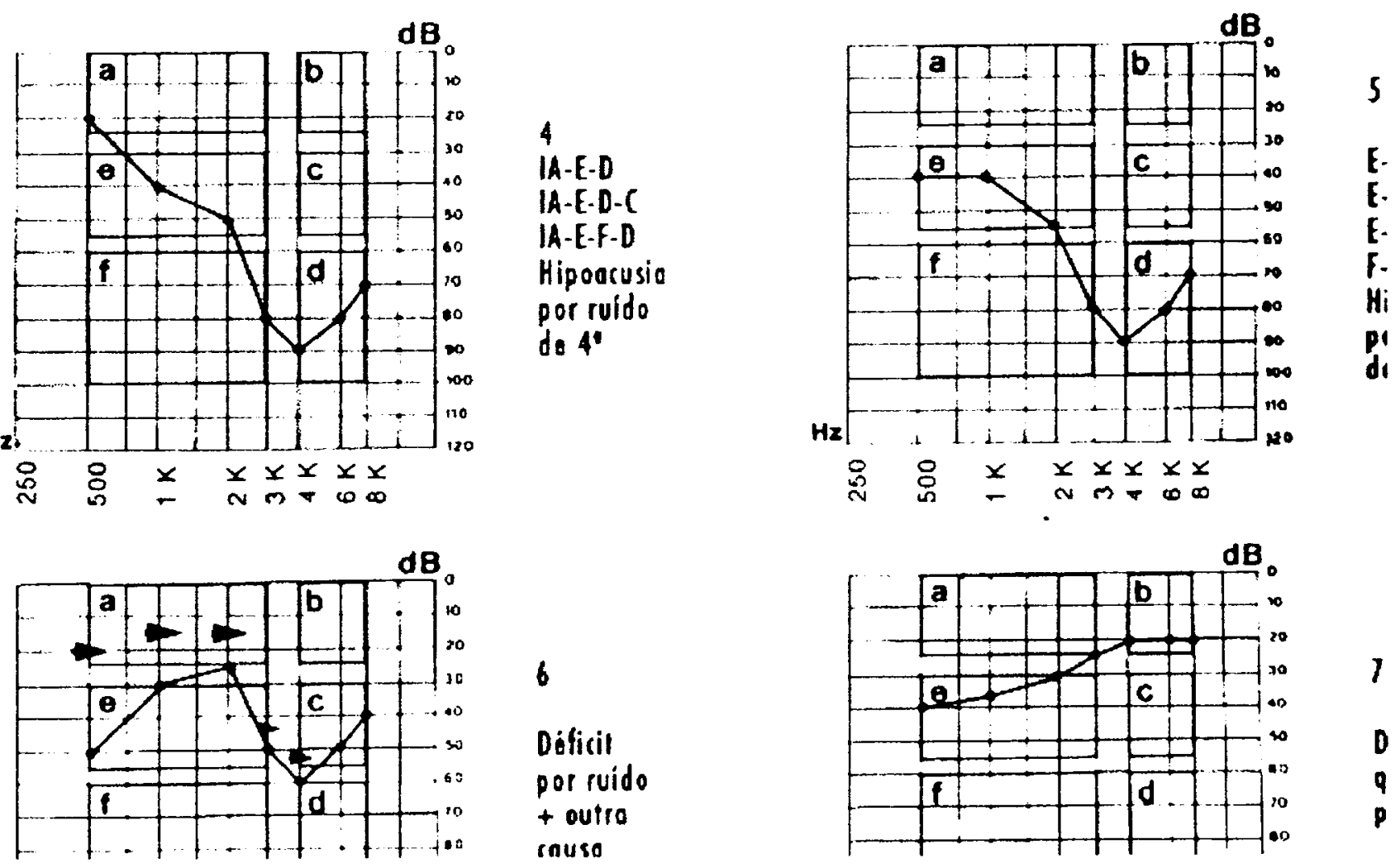
ANEXO 5 


\section{TERMO DE CONSENTIMENTO}

Estamos desenvolvendo uma pesquisa para verificar a existência de perdas auditivas e dificuldades de comunicação entre os motoristas de ônibus urbano. Serão realizadas entrevistas, exames audiológicos e grupos de orientação. Esses procedimentos não implicam em nenhum tipo de desconforto, requerem um tempo de realização de aproximadamente uma hora cada um e acontecerão na empresa, em horários previamente combinados. Eles são fundamentais para fornecer informações que indicarão as necessidades de melhoria do ambiente de trabalho e dos serviços de saúde prestados aos trabalhadores.

A participação nessa pesquisa é opcional e pode ser interrompida a qualquer momento. $O$ nome dos participantes e da empresa não serão divulgados.

A responsável pela pesquisa é Márcia Tiveron de Souza, que pode ser contatada pelo telefone 3259-9075, para quaisquer esclarecimentos.

Caso você concorde em participar, sentindo-se plenamente esclarecido e livre para escolher, por favor, assine este termo de consentimento.

Nome:

Assinatura:

Data: 1 